LUÍS EDUARDO DO AMARAL BERTAZI

SISTEMA DE INDICADORES PARA GESTÃO DA INOVAÇÃO EM PMES INDUSTRIAIS TRADICIONAIS

São Paulo

2017 


\title{
SISTEMA DE INDICADORES PARA GESTÃO DA INOVAÇÃO EM PMES INDUSTRIAIS TRADICIONAIS
}

\author{
Versão Original
}

Dissertação apresentada à Escola Politécnica da Universidade de São Paulo para obtenção do título de Mestre em Ciências

Área de Concentração: Engenharia de Produção

Orientador: Prof. Dr. Mario Sergio Salerno

São Paulo

2017 
Autorizo a reprodução e divulgação total ou parcial deste trabalho, por qualquer meio convencional ou eletrônico, para fins de estudo e pesquisa, desde que citada a fonte.

\section{Catalogação-na-publicação}

Bertazi, Luís Eduardo do Amaral

Sistema de indicadores para gestão da inovação em PMEs industriais tradicionais / L. E. A. Bertazi -- São Paulo, 2017.

$122 \mathrm{p}$.

Dissertação (Mestrado) - Escola Politécnica da Universidade de São Paulo. Departamento de Engenharia de Produção.

1.Indicadores de inovação 2.Auditoria de inovação 3.Desempenho de inovação 4.Gestão da inovação 5.PMEs I.Universidade de São Paulo. Escola Politécnica. Departamento de Engenharia de Produção II.t. 
Nome: BERTAZI, Luís Eduardo do Amaral

Título: Sistema de indicadores para gestão da inovação em PMEs industriais tradicionais

Dissertação apresentada à Escola Politécnica da Universidade de São Paulo para obtenção do título de Mestre em Ciências

Aprovado em:

Banca Examinadora

Prof. Dr.

Instituição:

Julgamento:

Prof. Dr.

Instituição:

Julgamento:

Prof. Dr.

Instituição:

Julgamento: 


\section{AGRADECIMENTOS}

Primeiramente, gostaria de agradecer a Deus por todas as oportunidades que me foram oferecidas, além de persistência e força de vontade para conciliar múltiplos interesses e projetos pessoais.

Agradeço aos meus pais pela educação que recebi ao longo destes anos e pelo apoio para que eu pudesse me concentrar em atingir meus objetivos.

Ao professor Mario Sergio Salerno, que desempenhou papel fundamental como orientador, sempre acessível e prestativo. Com profundo conhecimento no tema, direcionou com serenidade questões chave - teóricas e práticas - para o desenvolvimento do projeto NAGI e desta dissertação. Também agradeço aos professores Fernando José Barbin Laurindo e Raoni Barros Bagno pela preocupação e orientações dadas a esta pesquisa. Foram de suma importância para o redirecionamento que se fez necessário para a conclusão deste trabalho.

Aos amigos do Núcleo de Apoio à Gestão da Inovação da Escola Politécnica da Universidade de São Paulo (NAGI-USP) pelo estímulo ao crescimento intelectual e profissional e por compartilharem momentos que tornaram o período de mestrado mais suave. Em especial, agradeço ao meu amigo e sócio Felipe Bussinger Lopes pelas suas sugestões inteligentes, coerentes e assertivas durante a elaboração desta pesquisa e pela sua personalidade solícita, sempre disposta a ajudar.

Aos colegas de trabalho da Lidera Consultoria, mestrandos e doutorandos por estimularem o pensamento estratégico e gerencial e ampliarem meu leque de conhecimento por meio de suas discussões diárias. 


\section{RESUMO}

Os sistemas de mensuração e indicadores de desempenho de inovação são de grande utilidade para sua gestão. Embora explorados pela literatura acadêmica, as organizações possuem dificuldade em implementá-los. Em pequenas e médias empresas (PMEs), a limitação de recursos e capacidades organizacionais, além da dificuldade de acesso a informação, tornam os modelos teóricos pouco viáveis para serem implementados, sobretudo aqueles desenvolvidos para grandes empresas.

Neste contexto, esta pesquisa se propôs a desenvolver um sistema de indicadores mais adequado para gestão da inovação de produtos em PMEs industriais tradicionais de média ou baixa intensidade tecnológica.

A pesquisa foi conduzida por meio de revisão bibliográfica e estudos de caso em três fases. Iniciou-se com uma primeira compreensão da gestão da inovação em 21 empresas do perfil estudado, evoluindo até o desenvolvimento e teste da ferramenta, mediante verificação de sua aderência em três empresas selecionadas.

Nas duas primeiras fases da pesquisa, verificou-se que as empresas analisadas não utilizam processo sistemático de mensuração de desempenho de inovação. Quando muito, utilizam indicadores básicos de resultado, como quantidade de novos produtos desenvolvidos e faturamento advindo de novos produtos. As eventuais mensurações não são realizadas periodicamente e dificilmente geram aprendizados que contribuem para a organização ou para seus processos.

A ferramenta construída foi baseada em modelos pregressos, trazendo indicadores de entrada, processo e saída em ideação, conversão / desenvolvimento e difusão. Após verificação de aderência em três casos, o modelo proposto mostrou-se de fácil entendimento e aplicação. Embora possua as limitações naturais de uma ferramenta prescritiva, permite trazer ganhos relevantes para a gestão da inovação de produtos em PMEs do perfil estudado.

Palavras-chave: Indicadores de inovação. Auditoria de inovação. Desempenho de inovação. Gestão da inovação. PMEs. 


\begin{abstract}
Innovation performance measurement systems and indicators are very useful for its management. Although exploited by academic literature, companies find them difficult to implement. In small and medium enterprises (SMEs), limitation of resources and organizational capacities, besides difficulty of access to information, makes theoretical models little viable to be implemented, especially those developed for large companies.
\end{abstract}

In this context, this research proposed to develop a more adequate indicator system for product innovation management in traditional industrial SMEs of medium or low technological intensity.

Research was conducted through literature review and case studies in three phases. It began with initial understanding of innovation management in 21 enterprises of the profile studied, evolving to tool development and testing, by verifying its adherence in three selected companies.

In the first two phases of the research, it was verified that companies analyzed do not use a systematic process of measuring innovation performance. At most, they use basic result indicators, such as new products developed and revenues coming from new products. Eventual measurements are not carried out periodically and hardly generate learning that contributes to organization or its processes.

Developed tool was based on previous models, bringing input, process and output indicators in ideation, conversion / development and diffusion. After testing in three cases, proposed model was easy to understand and apply. Although it has natural limitations of a prescriptive tool, it allows to bring relevant benefits for product innovation management in SMEs of the studied profile.

Keywords: Innovation indicators. Innovation audit. Innovation measurement. Innovation management. SMEs. 


\section{LISTA DE FIGURAS}

Figura 1 - Cadeia de valor da inovação ..................................................23

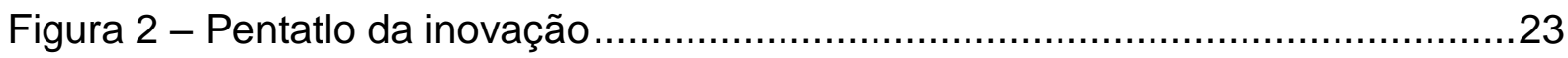

Figura 3 - Evolução da literatura em indicadores e sistemas de desempenho da

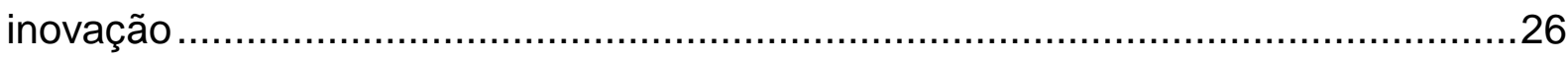

Figura 4 - Relação do P\&D com o retorno financeiro .....................................30

Figura 5 - Controle para execução do plano de inovação .................................33

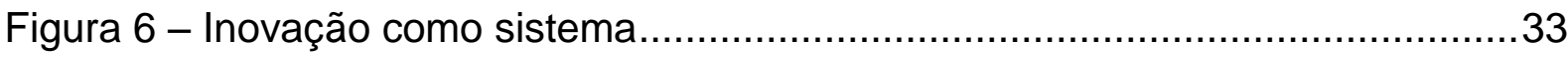

Figura 7 - Processo básico de inovação.................................................... 34

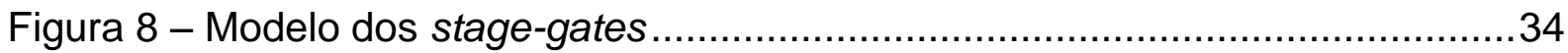

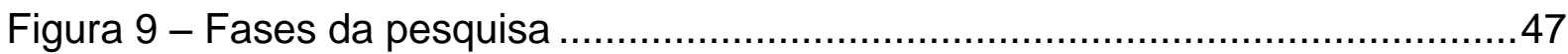

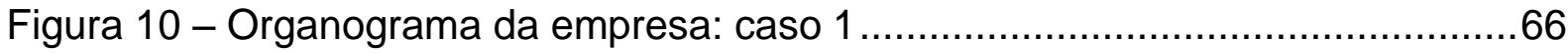

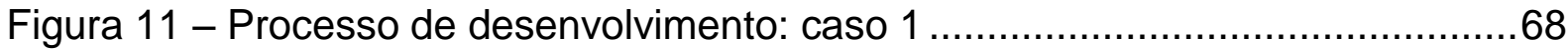

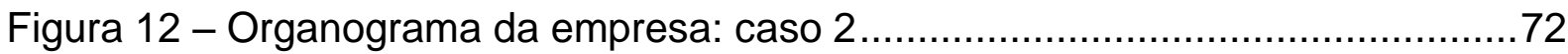

Figura 13 - Processo de desenvolvimento: caso 2 ............................................ 74

Figura 14 - Ferramenta desenvolvida para a fase III ................................... 84 


\section{LISTA DE QUADROS}

Quadro 1 - Características das inovações incrementais e radicais .20

Quadro 2 - Indicadores de desempenho de inovação mais utilizados. 31

Quadro 3 - Prós e contras de indicadores de inovação selecionados 31

Quadro 4 - Dimensões de desempenho .36

Quadro 5 - Mensuração de desempenho dos processos .37

Quadro 6 - Ferramenta de avaliação para gestão da inovação .38

Quadro 7 - Critérios para escolha do método de pesquisa .43

Quadro 8 - Processo de pesquisa proposto para o estudo .45

Quadro 9 - Roteiro de pesquisa da fase II .64

Quadro 10 - Indicadores de fácil e difícil aplicabilidade para empresas estudadas.. 82

Quadro 11 - Dimensões de fácil e difícil aplicabilidade para empresas estudadas ..83 


\section{LISTA DE TABELAS}

Tabela 1 - Empresas objeto desta pesquisa............................................49

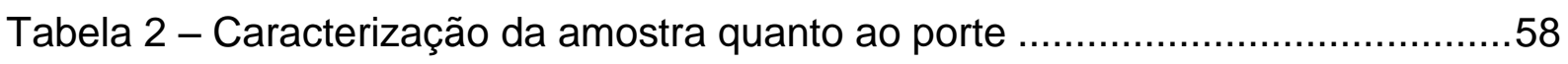

Tabela 3 - Caracterização da amostra quanto ao porte ..................................58

Tabela 4 - Preço dos produtos em comparação à concorrência ...........................58

Tabela 5 - Estratégia de inovação de empresas .........................................59

Tabela 6 - Modo pelo qual a inovação ocorre............................................59

Tabela 7 - Existência de processos formais por tipo ...................................6 60

Tabela 8 - Maiores desafios para inovação ................................................60 


\section{SUMÁRIO}

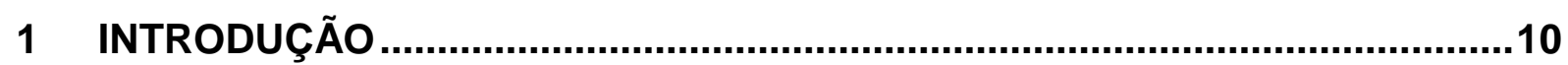

2 REVISÃO BIBLIOGRÁFICA...................................................................15

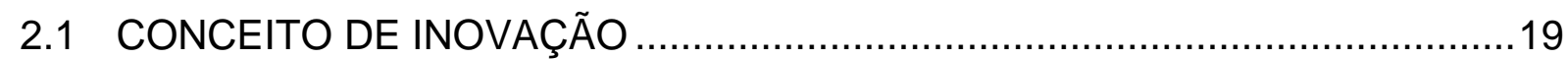

2.2 INOVAÇÃO COMO PROCESSO GERENCIÁVEL ........................................21

2.3 AVALIAÇÃO DO DESEMPENHO DA GESTÃO DA INOVAÇÃO ....................24

2.4 EVOLUÇÃO DA PESQUISA EM INDICADORES DE INOVAÇÃO ....................25

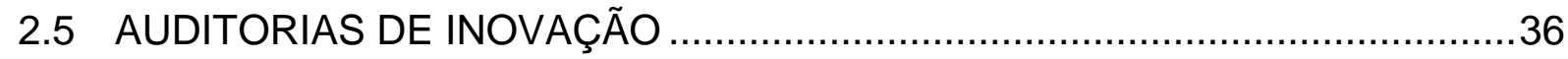

2.6 GESTÃO DA INOVAÇÃO EM PEQUENAS E MÉDIAS EMPRESAS ................38

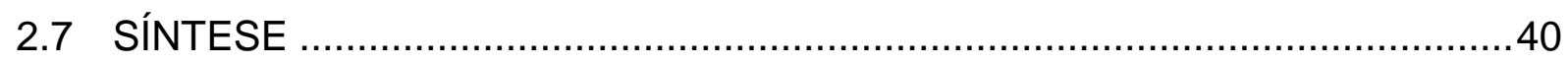

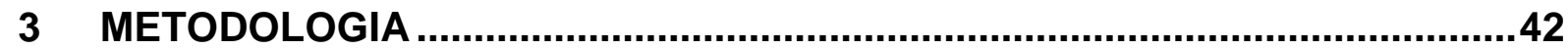

3.1 SELEÇÃO DE ABORDAGEM DE PESQUISA ......................................... 42

3.2 METODOLOGIA UTILIZADA COM ESTUDOS DE CASO ….......................44

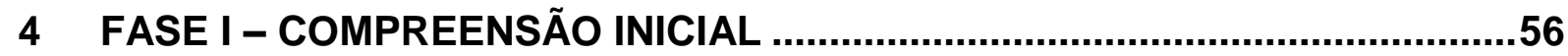

5 FASE II - PROCESSO DE INOVAÇÃO E SUA GESTÃO ................................63

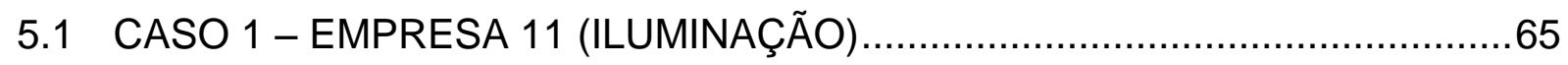

5.2 CASO 2 - EMPRESA 2 (AUTOPEÇAS) ……...........................................

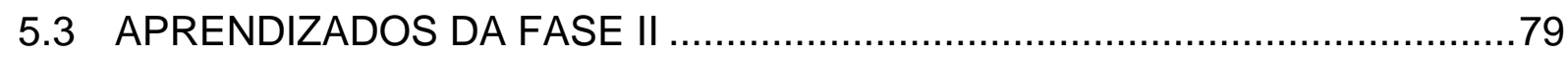

6 FASE III - CONSTRUÇÃO DE FERRAMENTA E ADERÊNCIA ......................81

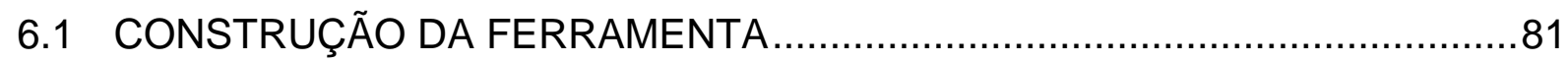

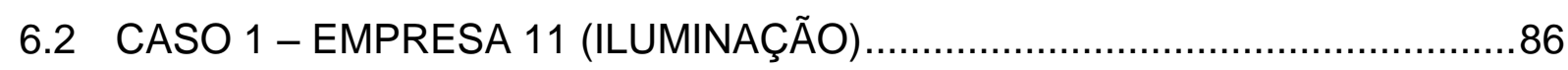

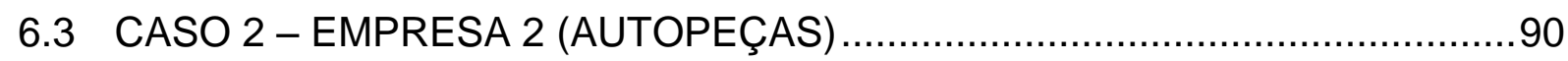

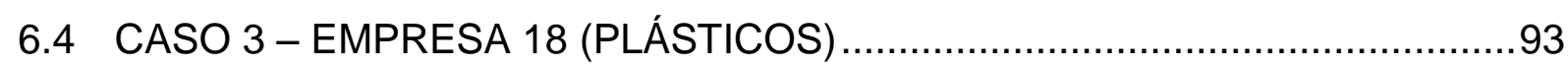

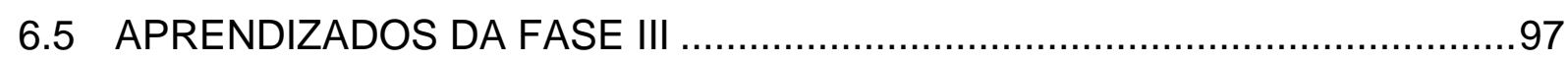

7 CONCLUSÃO E CONSIDERAÇÕES FINAIS .............................................101

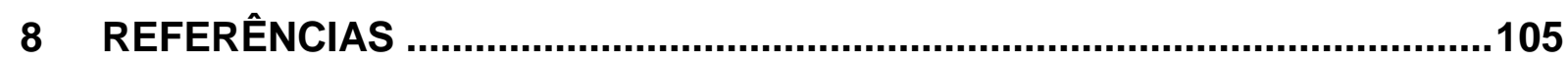

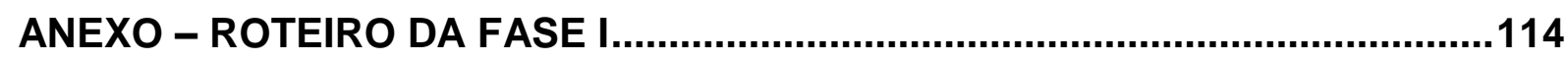




\section{INTRODUÇÃO}

Desde o final do século $X X$, há uma percepção geral de que os ambientes de negócios têm se tornado cada vez mais dinâmicos, com a necessidade das empresas se reinventarem continuamente para superar seus concorrentes e manter sua sustentabilidade no longo prazo. De fato, sabe-se que a capacidade inovadora é tão relevante quanto eficiência operacional e produtividade para que a empresa alcance a vantagem competitiva no longo prazo (BECATTINI, 1999).

Contudo, os investimentos em Pesquisa e Desenvolvimento (P\&D) por si só não resolvem o problema de desenvolver inovações sistemática e continuamente nas empresas, pois é fundamental gerir o processo de inovação, que inclusive podem ocorrer fora da função P\&D. Estudo realizado pela Booz Allen \& Hamilton (2006) vem ao encontro desta afirmação, apontando a ausência de correlação entre valor investido em iniciativas de P\&D e resultados obtidos pelas corporações, ainda que algum valor deva ser investido para que exista a possibilidade de se auferir os resultados de uma eventual inovação gerada.

A gestão da inovação é fundamental para racionalizar os investimentos realizados e buscar gerenciar riscos e incertezas, aumentando a probabilidade de sucesso e maximizando os resultados obtidos. Assim, para se obter resultados continuamente, é necessário aprimorar não apenas o desempenho da inovação, mas os processos pelos quais elas são desenvolvidas (CHIESA; COUGHLAN; VOSS, 1996). Diversos autores encontraram evidências que o sucesso competitivo é dependente da gestão dos processos de inovação e propuseram fatores que relacionam a gestão bem sucedida com os processos de inovação (COOPER, 1979; DE BRENTANI, 1991; DI BENEDETTO, 1996; ERNST, 2002; GLOBE; LEVY; SCHWARTZ, 1973; GRIFFIN, 1997; ROTHWELL, 1992).

Neely (1999) aborda a problemática da mensuração do desempenho da inovação como sendo um dos aspectos de gestão mais desafiadores e importantes para o êxito das organizações, tema que é tratado nesta dissertação.

No contexto geral da gestão empresarial, sabe-se que as métricas são de fundamental importância para a gestão, sendo possível monitorar indicadores e tomar decisões e ações relacionadas a estes resultados, compondo melhorias no curto, médio e prazo. 
No entanto, esse arcabouço naufraga ao tentar ser trasladado de forma literal para a gestão da inovação. Kerssens-van Drongelen e Nixon (2000) apontam para as características da inovação que tornam sua medição de desempenho complexa:

- Presença de elementos intangíveis como conhecimento, motivação e criatividade;

- Incerteza da duração envolvida do começo até o final do processo;

- Imprevisibilidade dos resultados.

A partir de análise da literatura, nota-se que a mensuração de aspectos relacionados à gestão da inovação é proposta com frequência, indo ao encontro da necessidade da academia e das empresas em compreender a eficácia das ações que visam este fim (BARCLAY, 1992; KIM; OH, 2002).

Oliveira (2010) destaca que, mesmo com a diversidade de conteúdo existente na literatura e disseminado pelas consultorias, há muitos problemas na implementação de ferramentas de gestão de desempenho e de indicadores de inovação no contexto real das empresas. Segundo pesquisa realizada pelo Boston Consulting Group (2006), apenas 32\% dos executivos americanos participantes - de grandes empresas afirmaram estar satisfeitos com as práticas existentes em sua organização para avaliar o desempenho da inovação, ainda que os demais também considerem esta verificação muito importante. Adicionalmente, externalizaram o fato de não saberem implementar indicadores para gerir inovação, o que demonstra a dificuldade em implementar os conceitos e as ferramentas já existentes. Em pesquisa mais recente da mesma consultoria (BCG, 2015), 77\% dos executivos das empresas participantes classificadas como fortes em inovação possuem processo eficiente de mensuração e monitoramento de indicadores de gestão de inovação, apontada como um dos fatores chave para o sucesso na função.

O uso de indicadores e sistemas de medição de desempenho da inovação são ferramentas de extrema importância para apoiar a gestão da inovação e, se bem escolhidos e utilizados para a empresa em análise, podem gerar vantagem competitiva por meio de inovação, materializada em produtos, serviços ou modelos de negócio diferenciados. O foco desta pesquisa, no entanto, está orientado a inovação para o desenvolvimento de novos produtos. 
Ainda que diversos modelos de indicadores e sistemas de indicadores de inovação tenham sido propostos, como auditorias de inovação, os diversos parâmetros que podem estar relacionados com o resultado final estão desagregados em estudos diferentes. A consequência é a ausência de uma ferramenta integrada que cubra todo o processo, que consiste no conjunto dos elementos desde a geração de ideias até o lançamento de produtos úteis e comercializáveis (ADAMS; BESSANT; PHELPS, 2006).

Adams, Bessant e Phelps (2006) evidenciaram tal constatação por meio de pesquisa realizada junto a especialistas em inovação em que todos os respondentes reconheceram a existência de uma série de medidas (ou indicadores) de inovação, evitando assim a necessidade do desenvolvimento de novas. Contudo, notou-se a ausência de modelos integrados e alinhados com as atividades de seus processos de inovação.

Embora haja oportunidades de pesquisa no tema em diversos perfis de organizações, o recorte desta está em pequenas e médias indústrias estabelecidas, pertencentes a setores de baixa ou média intensidade tecnológica. Mais especificamente, pretende-se focar nas inovações incrementais orientadas ao desenvolvimento de novos produtos.

A importância de estudar PMEs, segundo Audretsch et al. (2009), dá-se pelo fato de que contribuem significantemente com crescimento econômico, devendo ser objeto de estudo. Para elas, a inovação em produto, foco desta pesquisa, é um orientador importante de desempenho e crescimento em pequenas e médias empresas (ROSENBUSCH; BRINCKMANN; BAUSCH, 2011). Embora haja produção crescente de pesquisa com foco em empresas nascentes de base tecnológica, sabe-se que este tipo de PME não é maioria no Brasil, sendo útil estudos voltados àquelas tradicionais, de baixa e média intensidade tecnológica.

Moultrie, Clarkson e Probert (2007) destacam que a maioria da pesquisa em gestão da inovação para produtos foca basicamente em grandes empresas, ou falha em distinguir grandes e pequenas empresas.

Como peculiaridades, tem-se pelo lado positivo que as pequenas e médias empresas contam com maior flexibilidade como vantagem competitiva para inovação 
(FIEGENBAUM; KARNANI, 1991), tendo menor burocracia associada e um diretor ou dono - próximo para tomar as decisões necessárias rapidamente. Adicionalmente, a comunicação com colaboradores e clientes tende a ser mais rápida. Por outro lado, os recursos e as capacidades em gestão são mais limitados (MOULTRIE; CLARKSON; PROBERT, 2007), podendo se destacar aquelas relacionadas à organização e ao marketing, que tendem a apresentar lacunas quando comparadas às grandes empresas (VAN DE VRANDE et al., 2009).

Assim, um modelo de gestão de indicadores de inovação falharia ao pressupor uma lógica baseada nas melhores práticas de grandes empresas, ignorando o contexto, os propósitos e as restrições de uma pequena ou média empresa, como tempo, pessoas e recursos financeiros (BERENDS et al., 2014), justificando a relevância da pesquisa.

Neste contexto, a questão central de pesquisa é: "Quais os indicadores de inovação mais adequados para PMEs industriais tradicionais, de setores de média ou baixa intensidade tecnológica?"

Adicionalmente, pretende-se que sejam respondidas as seguintes perguntas:

- Quais sistemas de gestão e indicadores de inovação são atualmente utilizados por estas empresas?

- Quais métricas poderiam auxiliar estas empresas a inovar regularmente?

Embora a questão central possa remeter a um survey, adotou-se a abordagem de estudos de caso pela pesquisa ser exploratória, haver interesse em aprofundar os aspectos da mensuração de desempenho da inovação e necessidade de estudar qualitativamente o assunto. Esta escolha será abordada no capítulo 3, que trata de metodologia.

Para a questão central desenvolveu-se uma ferramenta simplificada a partir dos modelos propostos por Goffin e Mitchell (2005) e Adams, Bessant e Phelps (2006). O objetivo foi testar a aplicabilidade da ferramenta junto a indústrias selecionadas e questionar se provavelmente traria resultados positivos à gestão da inovação, uma vez que não haveria tempo hábil para mensurar os resultados efetivos antes da conclusão desta dissertação. 
Para discutir as questões da pesquisa, foram utilizadas como objeto pequenas e médias indústrias atendidas pelo Núcleo de Apoio à Gestão da Inovação (NAGI) da Escola Politécnica da Universidade de São Paulo. O NAGI será abordado mais adiante nesta dissertação, mas por ora é importante destacar que as empresas selecionadas guardam entre si características comuns, como: perfil industrial, empresas estabelecidas com baixo ou médio grau tecnológico, foco em inovações incrementais para desenvolvimento de produtos e equipe técnica reduzida para a função inovação.

Além desta seção introdutória, esta Dissertação está organizada nos seguintes capítulos:

- Capítulo 2 - Revisão bibliográfica: traz conceitos, ferramentas e aprendizados da literatura acadêmica nos temas de gestão e sistemas de desempenho e indicadores de inovação úteis para discutir a questão de pesquisa;

- Capítulo 3 - Metodologia: apresenta o processo de seleção da abordagem da pesquisa por estudos de caso e aborda as motivações para a divisão da etapa de campo em três fases;

- Capítulo 4 - Fase I - Compreensão inicial: reflete a primeira parte da etapa de campo, em que foram analisadas $21 \mathrm{PMEs}$ industriais estabelecidas. O capítulo traz os resultados iniciais da compreensão de aspectos gerais de gestão da inovação em empresas desse perfil.

- Capítulo 5 - Fase II - Processo de inovação e sua gestão: apresenta os resultados da segunda fase de campo a partir de dois casos selecionados, em que se buscou aprofundar a compreensão do processo de inovação e de sua gestão em PMEs.

- Capítulo 6 - Fase III - Construção de ferramenta e aderência: traz o processo de construção da ferramenta para gestão da inovação em PMEs industriais tradicionais e os resultados obtidos a partir da verificação de sua aderência junto a três empresas selecionadas.

- Capítulo 7 - Conclusão e considerações finais: discorre-se sobre aprendizados, limitações e oportunidades de pesquisa no tema. 


\section{REVISÃO BIBLIOGRÁFICA}

O levantamento sobre conceitos, tipologias e ferramentas de gestão de inovação, bem como de indicadores e sistemas de indicadores, deve ser realizado a fim de desenvolver quadro teórico do conhecimento existente na literatura. Desta forma, a pesquisa bibliográfica visa gerar maturidade sobre o tema para que seja tratada a questão geral de pesquisa, criados instrumentos e protocolos para o campo e posteriormente elaborar hipóteses para discutir as perguntas que orientam o estudo. Ainda contribui ao apoiar as análises e proposições sobre as principais características das unidades de análise - empresas objeto do estudo -, seus processos de inovação e modelos de gestão.

O processo de revisão bibliográfica iniciou-se com a leitura de artigos de referência no assunto, já conhecidos pelo pesquisador ou indicados por pesquisadores mais experientes. Esta abordagem inicial permitiu maior conhecimento dos conceitos existentes, de ferramentas utilizadas, de lacunas e limitações de pesquisa e do tipo de produção textual disponível.

Na sequência, utilizou-se a técnica de pesquisa "bola de neve", em que foram consultadas as referências dos artigos lidos na primeira etapa. Este processo permitiu compreender melhor a evolução dos conceitos e constructos ao longo do tempo, bem como o amadurecimento da pesquisa no assunto.

Por fim, buscou-se textos anteriormente não conhecidos pelo autor - e não indicados por outros pesquisadores - por meio da base de busca EBSCO com as palavras-chave relacionadas a seguir. A base foi selecionada pelo autor possuir acesso à categoria de serviço mais ampla oferecida em termos de disponibilidade de textos de engenharia e administração. A coleta e análise dos artigos foram realizadas em janeiro de 2016 e atualizadas em abril de 2017.

Os seguintes resultados foram obtidos para cada busca: 
- Primeira busca:

- Palavras-chave: innovation e indicators;

- Tipos de fonte: artigos em periódicos científicos e revistas acadêmicas (apenas textos completos);

- Total de artigos encontrados: 912.371 .

Como a primeira busca resultou em muitos artigos encontrados, a segunda busca restringiu a pesquisa pelo termo "gestão da inovação" (innovation management) e com variações e combinações dos termos "indicadores" (indicators), "medição" ou "mensuração" (measurement) e "métricas" (metrics).

- Segunda busca:

- Palavras-chave: "innovation management" e indicators;

- Tipos de fonte: artigos em periódicos científicos e revistas acadêmicas (apenas textos completos);

○ Total de artigos encontrados: 24.146.

- Palavras-chave: "innovation management" e measurement;

- Tipos de fonte: artigos em periódicos científicos e revistas acadêmicas (apenas textos completos);

- Total de artigos encontrados: 29.536.

- Palavras-chave: "innovation management" e metrics;

- Tipos de fonte: artigos em periódicos científicos e revistas acadêmicas (apenas textos completos);

- Total de artigos encontrados: 11.067 .

- Palavras-chave: "innovation management" e (indicators ou measurement ou metrics);

- Tipos de fonte: artigos em periódicos científicos e revistas acadêmicas (apenas textos completos);

- Total de artigos encontrados: 40.913 . 
Ainda com muitos resultados, foram observados diversos artigos que analisam indicadores de inovação em nível de país, seja por pesquisas relacionadas a economia ou gestão pública - no contexto de auxílio à construção de políticas públicas de inovação -, e não no nível de empresa. Assim, a terceira busca visou excluir estes textos, por meio do termo "nacional" (national), palavra mais evidenciada em amostra realizada.

- Terceira busca:

- Palavras-chave: "innovation management" e (indicators ou measurement ou metrics), mas não national;

- Tipos de fonte: artigos em periódicos científicos e revistas acadêmicas (apenas textos completos);

○ Total de artigos encontrados: 16.417 .

Ainda com grande quantidade de artigos, alguns relacionados a ciências sociais, restringiu-se a pesquisa por sete publicações de maior impacto no campo da administração e da engenharia de produção.

- Quarta busca:

- Palavras-chave: "innovation management" e (indicators ou measurement ou metrics), mas não national;

- Tipos de fonte: artigos em periódicos científicos e revistas acadêmicas (apenas textos completos);

- Publicações: (i) Journal of Product Innovation Management, (ii) European Journal of Innovation Management, (iii) International Journal of Innovation Management, (iv) R\&D Management, (v) International Journal of Production Research, (vi) Research Technology Management, (vii) Technovation;

o Total de artigos encontrados: 2.550 . 
Por fim, incluiu-se ainda um critério na pesquisa obrigando a existência da palavra "inovação" (innovation) no título dos artigos, de modo a restringir a busca e trazer uma quantidade de artigos possível de ser analisada, ainda que preliminarmente.

- Quinta busca:

- Título com a palavra innovation

- Palavras-chave: "innovation management" e (indicators ou measurement ou metrics) NOT national;

- Tipos de fonte: artigos em periódicos científicos e revistas acadêmicas (apenas textos completos);

- Publicações: (i) Journal of Product Innovation Management, (ii) European Journal of Innovation Management, (iii) International Journal of Innovation Management, (iv) R\&D Management, (v) International Journal of Production Research, (vi) Research Technology Management, (vii) Technovation;

- Total de artigos encontrados: 707.

A partir dos 707 artigos encontrados pela quinta busca, os textos foram ordenados pelo parâmetro relevância - critério da base EBSCO. Os títulos e as palavras-chave dos artigos foram analisados nesta ordem até que foram separados 100 artigos para leitura posterior do seu resumo e conclusão. Foram analisados os títulos de mais de quinhentos dos 707 artigos para a pré seleção e o critério foi dado pela aderência do tema do artigo ao propósito do artigo. Quando houve dúvida, preferiu-se incluir o artigo no grupo para posterior leitura.

Da análise dos 100 artigos quanto ao seu título, resumo e conclusão, foram selecionados 42 artigos para serem lidos integralmente. Considerando as demais fontes de pesquisa, já indicadas no início desta seção, como indicação de pesquisadores experientes e técnica "bola de neve", foram lidos 76 artigos no total para conclusão desta pesquisa. Deve-se ressaltar que nesta lista incluiu-se outros temas relevantes para a pesquisa, como textos de metodologia e de auditorias de inovação (audits), úteis para a criação de instrumentos e protocolo de pesquisa. 


\subsection{CONCEITO DE INOVAÇÃO}

O conceito de inovação foi definido por Schumpeter como sendo a capacidade de transformar uma ideia em algo comercialmente viável, que poderia ser tangibilizado em resultado financeiro. Nesta linha, inicia-se no processo de descoberta que deriva em invenções que então são exploradas comercialmente. Schumpeter (1961) declara que a inovação pode se manifestar de cinco diferentes formas:

- Introdução de um novo produto ou serviço, ou ainda de uma nova característica que ainda não fora lançada;

- Introdução de um novo método ou processo produtivo;

- Abertura de um novo mercado;

- Aquisição de uma nova fonte de matérias-primas, produtos semiindustrializados ou outros insumos;

- Desenvolvimento de um novo negócio que altere as formas de competição de uma indústria ou setor existente.

Após Schumpeter, diversos pesquisadores debateram o tema de inovação em seus estudos, principalmente quanto ao aspecto sobre o que seria ou não inovação, como Porter (1990), Cantú e Zapata (2006) e Tidd et al. (2008). Uma definição de destaque na literatura é a do Manual de Oslo (OECD, 2005) que traz o conceito como sendo "a implementação de um novo produto (bem ou serviço), ou processo, ou um novo método de marketing, ou um novo método organizacional nas práticas de negócios, na organização do local de trabalho ou nas relações externas." A novidade da OECD foi trazer a questão do método organizacional como sendo também um diferencial inovador, que portanto pode trazer impactos na competitividade e no resultado financeiro da empresa.

As características marcantes do processo de inovação nas empresas são pontuadas por Dosi (1998):

"A inovação está essencialmente relacionada à descoberta, experimentação, desenvolvimento, imitação e adoção de novos produtos, novos processos de produção e novos arranjos organizacionais". 
Por consequência, o autor aponta cinco efeitos relacionados à inovação:

- A incerteza associada, já que os resultados do esforço inovador não podem ser previstos antecipadamente (aspecto este que tem forte relação com a dificuldade de mensuração);

- Oportunidades tecnológicas calcadas nos avanços da ciência e de pesquisa;

- Estruturação interna das empresas para lidar com a complexidade da gestão da inovação, como a criação de áreas de P\&D, por exemplo;

- Introdução dos conceitos learning by doing e learning by using;

- Inovação tecnológica como sendo acumulativa, pois decorre da experiência e do aprendizado das empresas no decorrer do tempo.

Para fins desta pesquisa, é importante distinguir as inovações incrementais das radicais, pois o foco deste trabalho está no primeiro grupo, que pode ser mais facilmente enquadrado nos processos de gestão já consagrados na literatura acadêmica. Diversos autores fizeram uma distinção clara entre as inovações radicais e incrementais, como Leifer et al. (2000), Christensen (2002), O'Connor et al. (2002), Koberg et al (2003), Reis (2004), Cantú e Zapata (2006) e Forsman (2009). Na tabela a seguir é apresentada uma comparação entre estas duas formas de inovação, suas características e especificidades.

Quadro 1 - Características das inovações incrementais e radicais

\begin{tabular}{|l|l|l|}
\hline $\begin{array}{l}\text { Tempo dos } \\
\text { projetos }\end{array}$ & $\begin{array}{l}\text { Inovação incremental } \\
\text { anosíodos curtos (seis meses a dois }\end{array}$ & $\begin{array}{l}\text { Inovação radical } \\
\text { Períodos longos, podendo superar dez } \\
\text { anos }\end{array}$ \\
\hline Trajetória & $\begin{array}{l}\text { Há um caminho linear e contínuo do } \\
\text { conceito à comercialização } \\
\text { seguindo passos determinados }\end{array}$ & $\begin{array}{l}\text { O caminho é marcado por múltiplas } \\
\text { descontinuidades que devem ser } \\
\text { integradas. O processo é esporádico } \\
\text { com paradas e recomeços, } \\
\text { postergações e retornos. As mudanças } \\
\text { de trajetórias ocorrem em resposta a } \\
\text { eventos imprevisíveis e descobertas }\end{array}$ \\
\hline $\begin{array}{l}\text { Geração de } \\
\text { ideias e } \\
\text { reconhecimento } \\
\text { de } \\
\text { oportunidades }\end{array}$ & $\begin{array}{l}\text { Geração de ideias e o } \\
\text { reconhecimento de oportunidades } \\
\text { ocorrem na linha de frente. Eventos } \\
\text { críticos podem ser antecipados }\end{array}$ & $\begin{array}{l}\text { Geração de ideias e o reconhecimento } \\
\text { de oportunidades ocorrem de forma } \\
\text { esporádica ao longo do ciclo de vida, } \\
\text { frequentemente em resposta às } \\
\text { descontinuidades na trajetória do projeto }\end{array}$ \\
\hline Processos & $\begin{array}{l}\text { Processo formal aprovado caminha } \\
\text { da geração de ideias através de } \\
\text { desenvolvimento e comercialização }\end{array}$ & $\begin{array}{l}\text { Há um processo formal para obtenção e } \\
\text { administração de recursos. As incertezas } \\
\text { são enormes para tornar o processo } \\
\text { relevante. O processo formal passa a ter } \\
\text { seu valor somente quando o projeto } \\
\text { entra nos últimos estágios de } \\
\text { desenvolvimento }\end{array}$ \\
\hline
\end{tabular}




\begin{tabular}{|l|l|l|}
\hline & \multicolumn{1}{|c|}{ Inovação incremental } & \multicolumn{1}{c|}{ Inovação radical } \\
\hline Participantes & $\begin{array}{l}\text { Atribuído a um grupo de diversas } \\
\text { áreas. Cada membro tem sua } \\
\text { responsabilidade definida dentro de } \\
\text { sua área de conhecimento }\end{array}$ & $\begin{array}{l}\text { Os participantes principais vão e vem ao } \\
\text { longo dos estágios iniciais do projeto. } \\
\text { Muitos são parte de um grupo informal } \\
\text { que cresce em torno de um projeto de } \\
\text { inovação radical. Os participantes } \\
\text { principais tendem a ser indivíduos de } \\
\text { várias competências }\end{array}$ \\
\hline $\begin{array}{l}\text { Estruturas } \\
\text { organizacionais }\end{array}$ & $\begin{array}{l}\text { Tipicamente um grupo de áreas } \\
\text { diversas trabalhando dentro de uma } \\
\text { unidade de negócios }\end{array}$ & $\begin{array}{l}\text { O projeto frequentemente inicia-se na } \\
\text { P\&D, migra para um processo de } \\
\text { incubação e se move para ser o projeto } \\
\text { central ou objetivo da empresa }\end{array}$ \\
\hline
\end{tabular}

Fonte: Adaptado de Leifer et al. (2000)

As inovações incrementais podem ser gerenciadas como processo desde a geração de ideias até a comercialização, assim como apresentado na tabela e na seção a seguir. No caso de inovação de produtos em pequenas e médias indústrias - foco desta pesquisa -, estas atividades são executadas majoritariamente pela função da organização responsável pelo desenvolvimento de produtos, ainda que não esteja formalmente constituída.

De acordo com Moultrie, Clarkson e Probert (2007), devido aos recursos limitados das pequenas e médias empresas estabelecidas, é incomum que elas conduzam portfólios de inovação com projetos simultâneos de alto, médio e baixo risco. Assim, elas normalmente tendem a selecionar aqueles de menor risco, de natureza incremental.

\subsection{INOVAÇÃO COMO PROCESSO GERENCIÁVEL}

Após as primeiras décadas de discussão sobre inovação, começaram a surgir os estudos que procuraram descrever os seus processos típicos, de modo a generalizar o modo pelo qual a inovação surgia e se desenvolvia e também como este processo poderia ser gerido pelas empresas. O esforço estava concentrado em criar métodos de gestão de modo a não depender de um especialista, gênio ou "guru", ou ainda de um golpe de sorte para desenvolver a competitividade por meio das inovações. 
Utterback (1971) foi um dos primeiros a introduzir o conceito de inovação como um processo sistemático e gerenciável, apresentando um modelo voltado ao desenvolvimento de inovações tecnológicas composto por três fases:

- Geração de ideia: reconhecimento da necessidade atual, reconhecimento dos meios técnicos necessários para suprir a necessidade e síntese das informações para criação de ideia ou proposta para desenvolvimento;

- Resolução do problema: divisão do problema em subproblemas, definição dos objetivos técnicos, designação de alternativas de soluções e avaliação das alternativas em relação aos objetivos e às prioridades;

- Implementação e difusão: desenvolvimento do processo produtivo e introdução do produto no mercado.

Posteriormente, diversos outros autores estudaram e descreveram a inovação como processo, sugerindo suas próprias ferramentas em seus textos, como Block e MacMillan (1985), Wheelwright e Clark (1992), Cooper (2008), Tidd, Bessant e Pavitt (2005), Hansen e Birkinshaw (2007), Goffin e Mitchell (2005) e Salerno et al. (2015). Os modelos propostos são mais aderentes às inovações incrementais, cuja definição foi apresentada na seção anterior, auxiliando na gestão da inovação e de suas incertezas associadas, reduzindo riscos e o tempo total de desenvolvimento.

Wheelwright e Clark (1992) introduzem o conceito de funil de inovação, em que devem haver diversas ideias no início de um processo de gestão (entradas) para que se gerem poucas inovações em potencial (saídas). Assim, a cada etapa do processo inovador, haveria a mortalidade de diversas ideias, priorizando esforços e economizando recursos valiosos para a organização, como capital e horas disponíveis de seus colaboradores.

Hansen e Birkinshaw (2007) apresentam um modelo em que as ideias podem ser geradas de fontes externas à empresa e faz uma divisão mais clara entre as etapas de geração de ideias, conversão / desenvolvimento e difusão (ou lançamento). As etapas sugeridas pelos pesquisadores são apontadas a seguir. 
Figura 1 - Cadeia de valor da inovação

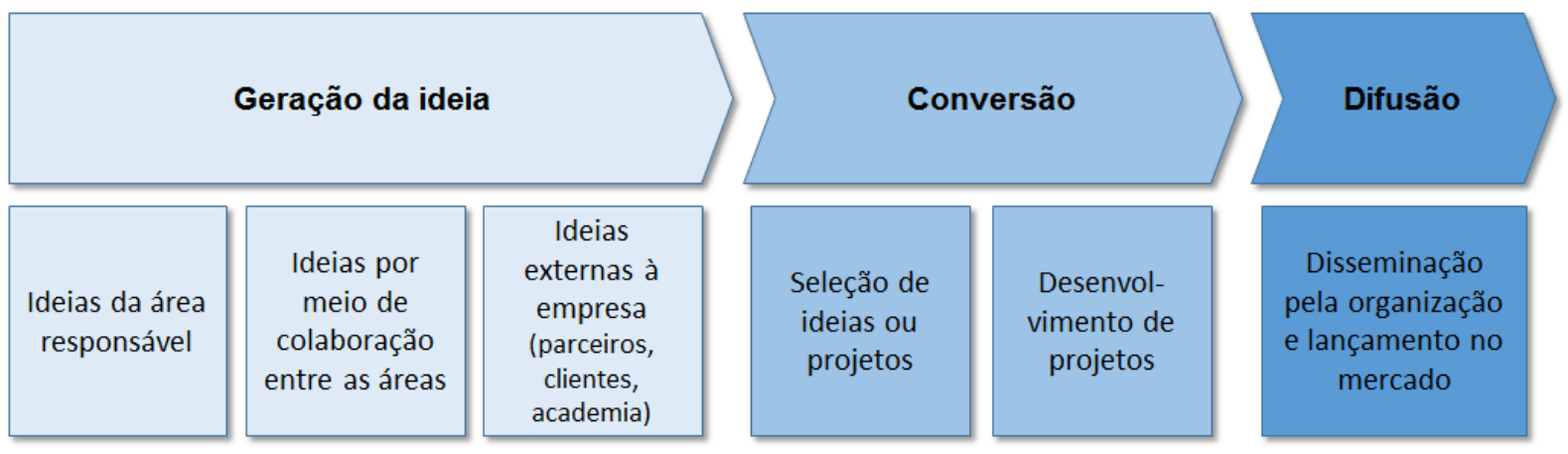

Fonte: Adaptado de Hansen e Birkinshaw (2007).

A geração da ideia pode ocorrer a partir da área responsável pela função inovação, a partir de áreas correlatas ou por meio de colaboração entre áreas e ainda por parceiros externos, como fornecedores, clientes, consumidores finais e universidades, por exemplo. A etapa de conversão engloba as atividades de seleção de ideias ou iniciativas, priorização e posterior desenvolvimento de projetos. Por fim, a etapa de difusão visa disseminar a inovação dentro da própria organização e para o mercado.

Goffin e Mitchell (2005) expandiram o modelo anterior apresentado para o que chamaram de "pentatlo da inovação", em que foram incluídas as camadas em que a inovação se desenvolve, que compreendem a estratégia corporativa e pessoas e organização. Os tópicos em destaque representam elementos pertencentes a cada um dos cinco blocos do pentatlo.

Figura 2 - Pentatlo da inovação

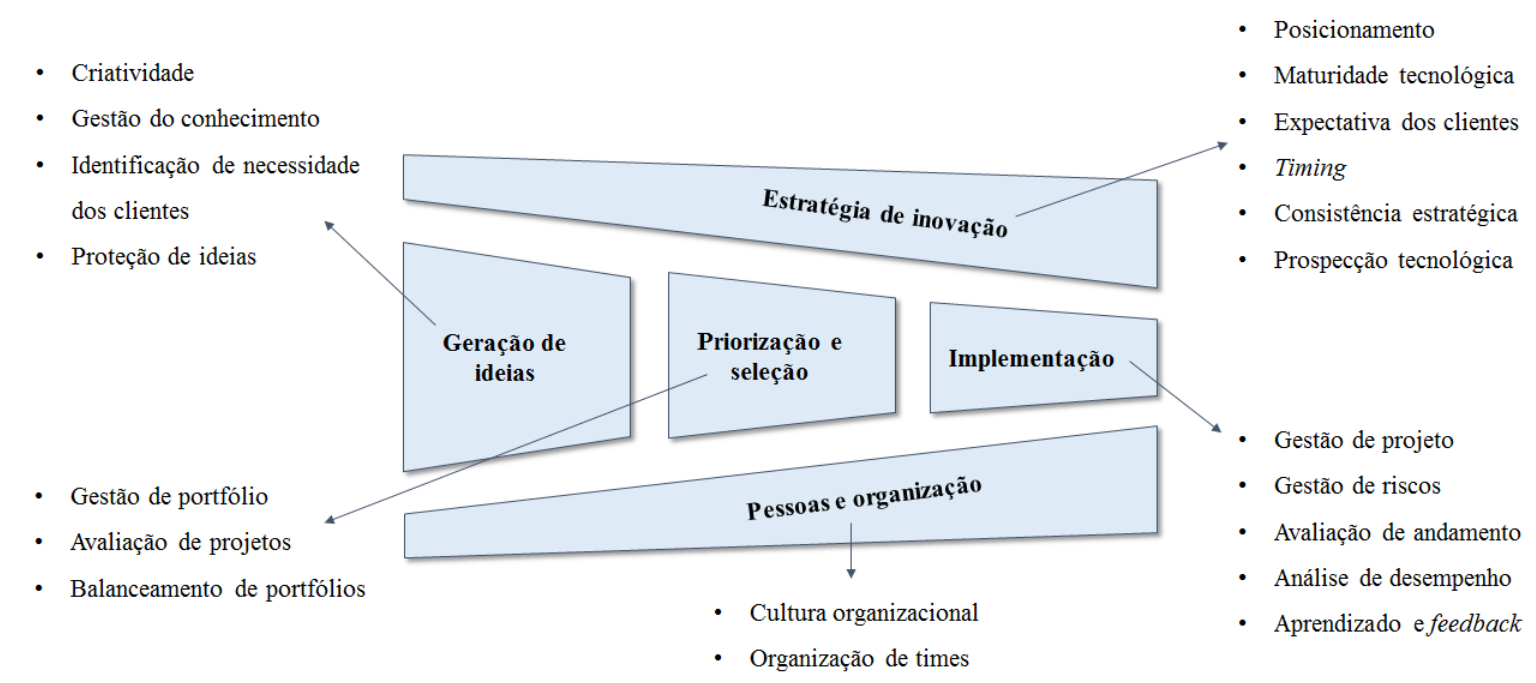

Fonte: Adaptado de Goffin e Mitchell (2005). 


\subsection{AVALIAÇÃO DO DESEMPENHO DA GESTÃO DA INOVAÇÃO}

Historicamente, conforme aumentava o interesse pelo desenvolvimento de processos para gerir a inovação, iniciou a preocupação em como avaliar e mensurar os resultados. Afinal, a avaliação atuaria como o elo entre a estratégia e a eficiência dos recursos empregados na atividade inovadora.

Vasconcellos e Ohayon (1988) apontam em seu estudo algumas motivações para justificar a importância da avaliação formal do esforço de inovação:

- Verificação do cumprimento dos objetivos dos projetos e os motivos das distorções em relação ao resultado esperado;

- O processo de avaliação gera aprendizado de boas práticas e melhora projetos futuros;

- Desempenho tende a melhorar quando se sabe que está sendo avaliado;

- Processos de avaliação aumentam a definição de critérios e objetivos, o que torna as diretrizes mais claras para os envolvidos;

- Informações obtidas são úteis para a revisão da estratégia da empresa.

Entretanto, devido a aspectos como incerteza e novidade relacionados à inovação, é muito complexo avaliar a capacidade inovadora por meio de medidas e ferramentas. Adams, Bessant e Phelps (2006) afirmam que não há consenso na academia sobre quais variáveis devam ser consideradas para medi-lo - e nem a relação entre elas e que há uma gama de abordagens buscando a sua avaliação por meio de diferentes medidas, porém é difícil identificar uma literatura que sintetize os aprendizados em uma única metodologia. Neste contexto, este tema de estudo torna-se importante, uma vez que ainda há aspectos a serem explorados na busca de expansão do conhecimento estabelecido no assunto.

Antes de aprofundar a questão dos indicadores para gestão da inovação, cabe uma definição pelo que se entende como indicador de desempenho neste texto. Segundo Franceschini et al. (2007 apud OLIVEIRA, 2010), trata-se da "informação qualitativa e/ou quantitativa de um fenômeno (ou um processo, ou um resultado), que torna possível a avaliação de sua evolução no tempo e se os objetivos estão sendo 
alcançados, orientando ações e decisões". Adicionalmente, as medidas de desempenho não devem estar dispersas, mas estruturadas e organizadas, constituindo assim a necessidade de um sistema de medição de desempenho.

Os sistemas de medição de desempenho tradicionais mostraram-se ineficientes para ambientes que buscam a inovação e por este motivo há oportunidades de pesquisa no aprofundamento do tema. Apenas como exemplo, Hayes e Abernathy (1980) exploram em seu artigo a questão do declínio das empresas americanas no final da década de 70 , estando este relacionado - junto a outros fatores - às estratégias adotadas pelos executivos voltadas ao curto prazo, orientadas por indicadores financeiros que desestimulavam o desenvolvimento de inovações de ruptura.

\subsection{EVOLUÇÃO DA PESQUISA EM INDICADORES DE INOVAÇÃO}

O primeiro esforço em medir e avaliar a inovação se deu pela tentativa de adaptação das ferramentas tradicionais de gestão, basicamente voltadas a indicadores de natureza financeira (FOSTER et al., 1985; MCGRATH; ROMERI, 1994). Posteriormente, buscou-se utilizar outros indicadores, não financeiros, para analisar a eficácia e a eficiência no esforço inovador (HODGE Jr., 1963; COOK, 1966; ANDREASSI, 1999). Nas décadas seguintes, algumas escolas de pensamento desenvolveram propostas para sistemas de medição de desempenho da inovação, cada uma com enfoque um pouco diferente.

Para descrever a evolução da pesquisa em indicadores de inovação, será utilizado como referência o quadro teórico desenvolvido por Oliveira (2010), que sistematizou as linhas de pensamento em um diagrama que remonta a cronologia dos estudos realizados em indicadores e sistemas de indicadores de medição de desempenho da inovação. É importante destacar que, durante o histórico da pesquisa no assunto, por muitas vezes o termo inovação de modo mais abrangente não era utilizado nos textos, mas sim termos como inovação tecnológica, ou pesquisa e desenvolvimento (P\&D), ou desenvolvimento de novos produtos, por exemplo. 
Figura 3 - Evolução da literatura em indicadores e sistemas de desempenho da inovação

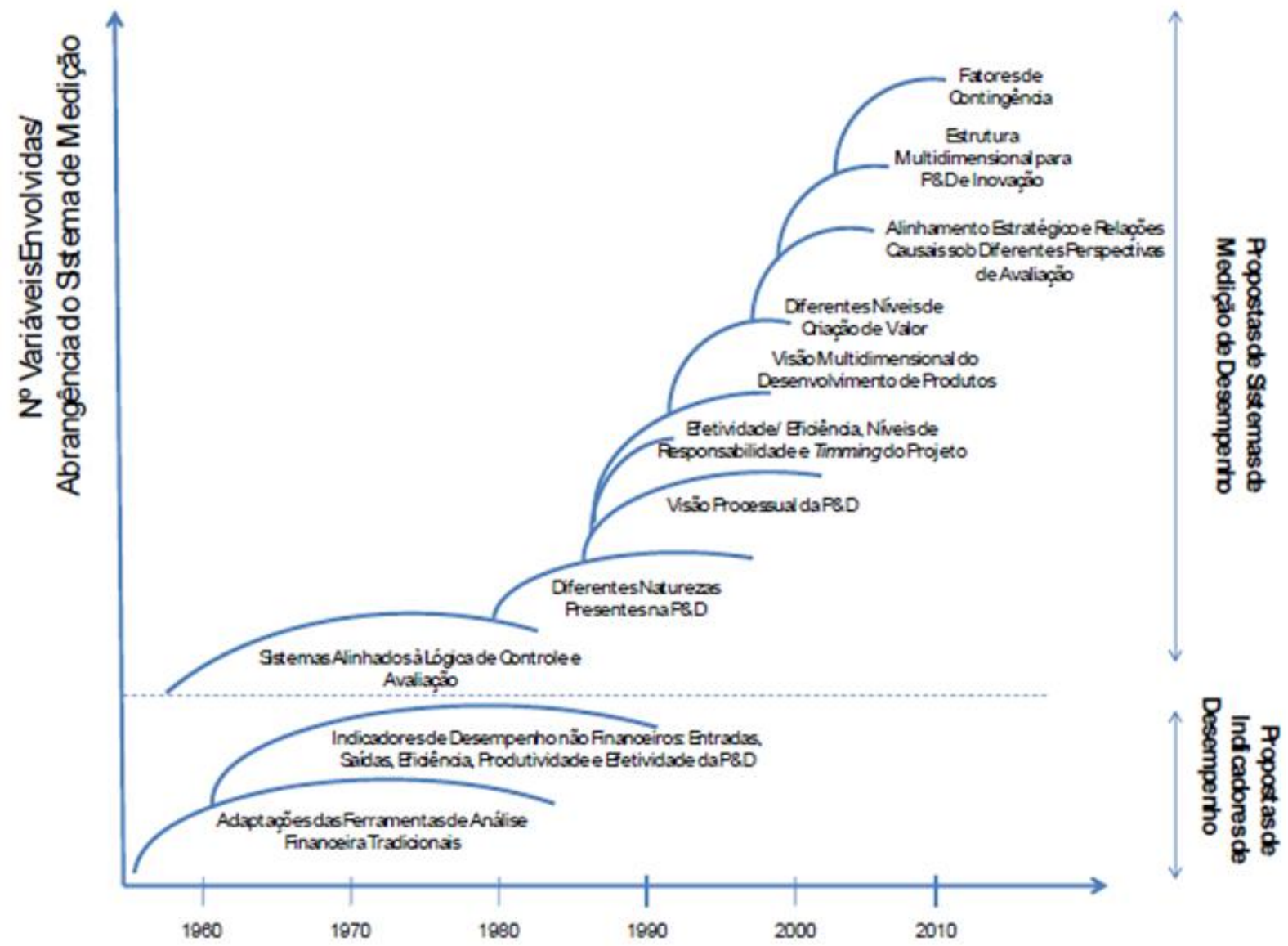

Fonte: Oliveira (2010).

A seguir são sintetizadas cada uma das linhas teóricas do quadro apresentado por Oliveira (2010) e suas contribuições em termos de princípios para a construção de sistemas de indicadores para gerir o processo de inovação:

- Adaptações das ferramentas de análise financeiras tradicionais: primeiras tentativas de avaliação de desempenho de inovação por meio de ferramentas financeiras, como retorno sobre investimento (ROI), taxa interna de atratividade (TIR) e valor presente líquido (VPL). Exemplos de trabalhos são os de Foster et al. (1985), que desenvolveram um método para o cálculo de retorno sobre investimentos de pesquisa e desenvolvimento, e o de McGrath e Romeri (1994), com seu índice de eficácia sobre os investimentos realizados em inovação. 
- Indicadores de desempenho não financeiros - entradas, saídas, eficiência, produtividade e eficácia: desenvolvimento de indicadores de desempenho não financeiros, como alocação de recursos (COOK, 1966), benchmarking (HODGE Jr., 1963), patentes, artigos e resultados de inovação (ANDREASSI, 1999). Os indicadores propostos por estes trabalhos possuem a peculiaridade de dependerem de características específicas das empresas, como porte e setor industrial, e do estágio em que a P\&D - ou processo de gestão de inovação - se encontra na organização.

- Sistemas alinhados à lógica de controle e avaliação: nestes estudos, o sistema de indicadores de desempenho da gestão da inovação possui duas perspectivas distintas: a de controle e a de avaliação. A primeira deve garantir que a atividade relacionada à inovação seja executada de acordo com o planejado. A segunda, por sua vez, deve garantir que sejam alcançados os resultados planejados. Como exemplo de autor desta linha de pesquisa, podese citar o trabalho de Rubenstein (1957).

- Diferentes naturezas presentes: caracteriza-se pela proposição de sistemas de medição para o desempenho de inovação que estabelecem os resultados técnicos com os econômicos relacionados às três fases de pesquisa (fundamental, aplicada e de desenvolvimento) dentro de perspectivas de curto, médio e longo prazos (QUINN, 1960; GEE, 1975; COLLIER, 1977).

- Visão processual: a partir do momento em que a inovação é vista como um processo gerenciável, o sistema de avaliação da gestão da inovação se concentra em indicadores de entrada, de processo, de saída e de resultados durantes as etapas do processo inovador (BROWN; SVENSON, 1988). Os sistemas de indicadores propostos nestes estudos para mensurar 0 desempenho contam com informações qualitativas e quantitativas por etapas do processo. Existirão indicadores que estarão sob total domínio da função inovação na empresa e outros que estarão sob domínio parcial, pois possuem interação com outras áreas funcionais da organização, ou mesmo com ambiente externo a ela (SCHUMMAN et al., 1995; CHIESA; MASELLA, 1996). Destaca-se nesta linha de pesquisa o modelo de stage-gates de Cooper (2008), que ainda que tenha sido formatado para os processos de desenvolvimento de 
produtos, propõe um sistema de indicadores para os marcos de acompanhamento dos projetos.

- Eficácia e eficiência, níveis de responsabilidade e timing do projeto: sistemas de avaliação que consideram a relação entre o resultado (eficácia e eficiência), os níveis de responsabilidade de uma área ou unidade de negócio dentro de uma organização e o timing envolvido - fase de planejamento ou de controle (CORDERO, 1990).

- Visão multidimensional do desenvolvimento de produtos: sistemas de avaliação de processo de desenvolvimento de produtos, que consideram dimensões como financeiro, produto, satisfação dos clientes, nível do programa e nível da empresa, e o relacionam com a estratégia de inovação adotada pela empresa. Destacam-se nesta linha teórica os textos de Griffin e Page (1993) e Griffin e Page (1996).

- Diferentes níveis de criação de valor: proposição de sistema de indicadores que consideram elementos em diferentes níveis para avaliar a geração de valor para a gestão de inovação da empresa. Pode-se citar a pesquisa de Tipping e Zeffren (1995), que trabalha com os níveis de processo de inovação, valor de ativos tecnológicos, integração com o negócio e criação de portfólio.

- Alinhamento estratégico e relações causais sob diferentes perspectivas de avaliação: proposição de sistemas de indicadores que consideram elementos contidos no conceito do Balanced Scorecard (BSC): alinhamento estratégico, relação com a perspectiva financeira, clientes, processos internos e aprendizado e crescimento. Podem-se citar nesta categoria de pesquisa os textos de Kerssens-Van Drongelen e Cook (1997), Bremser e Barsky (2004) e Osama (2006).

- Estrutura multidimensional para P\&D e inovação: sistema de indicadores para avaliação da P\&D e da inovação calcados nos processos principais de gestão da inovação, processos de gestão e habilitadores. Consistem em:

- Processos principais: geração de conceitos, desenvolvimento de produtos, aquisição e transferência de tecnologia, networking (CHIESA, 
1996; VERHAEGE; KFIR, 2002), comercialização (ADAMS; BESSANT, PHELPS, 2006) e implementação (GOFFIN; MITCHELL, 2005);

- Processos de gestão: gestão de portfólio e gestão de projetos (ADAMS; BESSANT; PHELPS, 2006);

- Habilitadores: desenvolvimento de recursos financeiros e humanos, uso efetivo de sistemas e ferramentas de gestão, liderança e direção (CHIESA, 1996), gestão do conhecimento, estratégia de inovação, cultura e organização (ADAMS; BESSANT; PHELPS, 2006) e estrutura e pessoas (GOFFIN; MITCHELL, 2005).

- Fatores de contingência: sistema de medição de desempenho da inovação que considere elementos macro da organização, como sua estratégia (LOCH et al., 1996), fatores contingenciais, como os elementos presentes na P\&D e as características do sistema de gestão da organização, e os elementos do sistema de avaliação (perspectivas da avaliação, atributos de desempenho, metas organizacionais, entre outros). Destacam-se nesta linha de pesquisa uma gama diversa de autores, incluindo Frattini et al. (2006), Ojanen e Vuola (2006), Osama (2006) e Chiesa et al. (2008). Deve-se considerar, contudo, que inserem-se nesta categoria textos com planos de análise distintos: estratégico, tático e operacional da gestão da inovação na empresa.

De modo a aprofundar alguns dos estudos citados anteriormente, a seguir são apresentados mais profundamente alguns trabalhos de maior relevância para a evolução da pesquisa em indicadores de inovação.

Uma das primeiras tentativas em sistematizar o esforço de relacionar os recursos na atividade de inovação com o resultado gerado foi Quinn (1960), que elaborou um quadro conceitual para relacionar contabilidade com o esforço inovador, utilizando cálculos de retorno sobre o investimento.

Posteriormente, diversos outros autores procuraram estudar o tema, sobretudo utilizando de ferramentas de análise financeiras tradicionais. Um dos estudos que se destacou nesta linha de pesquisa foi o de Foster et al. (1985), que buscou relacionar 
o retorno como sendo a receita de vendas proveniente de investimentos em pesquisa e desenvolvimento (P\&D). O diagrama abaixo ilustra seu racional, em que define 0 retorno como reflexo da produtividade da função de inovação e o ganho do P\&D em termos de relação receita pelo investimento:

Figura 4 - Relação do P\&D com o retorno financeiro

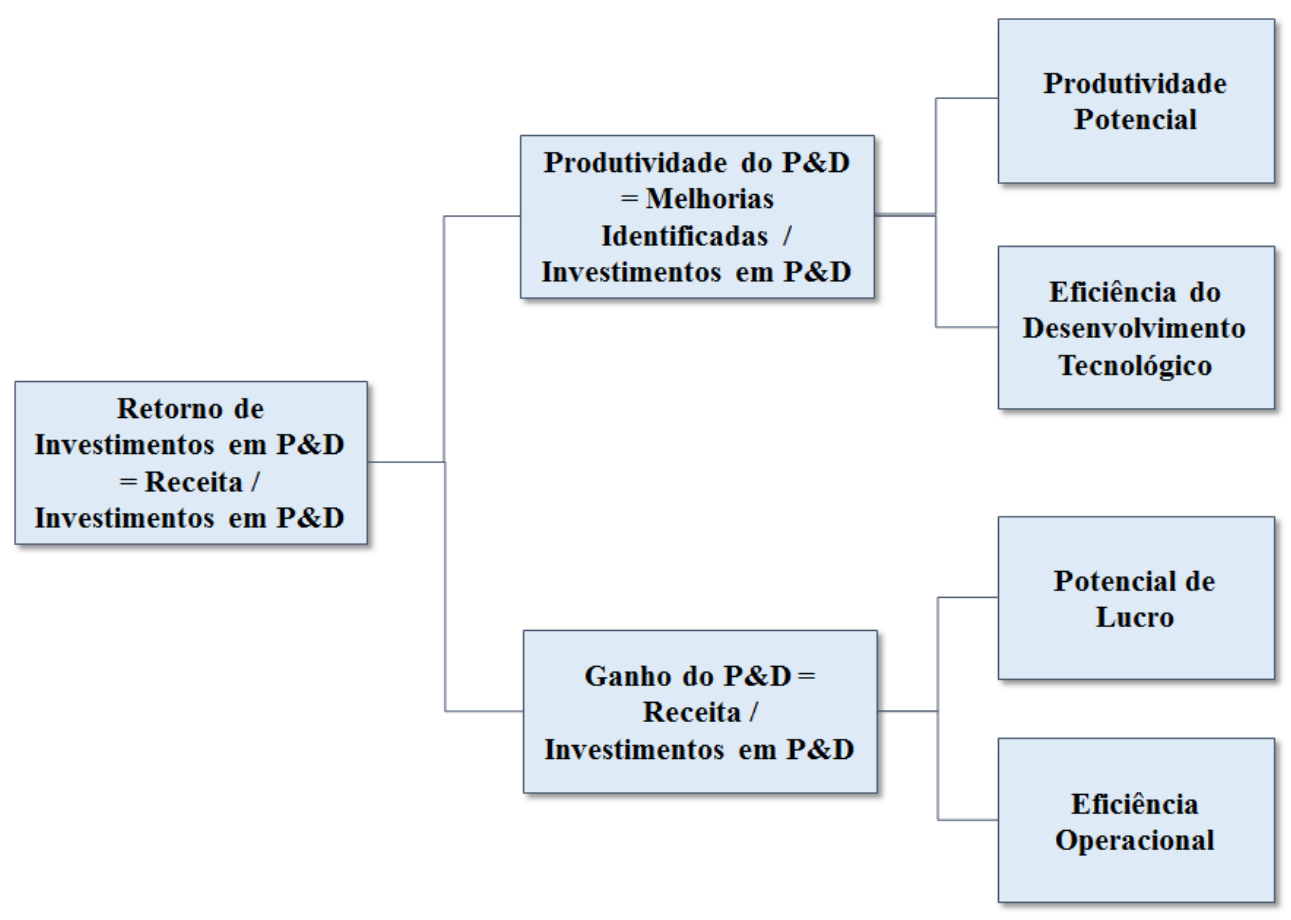

Fonte: Adaptado de Foster et al. (1985).

Em um segundo momento, surgiu uma outra linha de pesquisa para a mensuração do esforço de inovação, em que os indicadores não eram mais dominantemente financeiros. Hodge Jr. (1963), por exemplo, contrapôs-se ao modelo estabelecido sugerindo a utilização de indicadores não financeiros para avaliar resultados de P\&D e sua produtividade a partir do sucesso de patentes, publicações e produtos lançados. Moser (1985), em um estudo de abordagem quantitativa (survey), aplicou um questionário em indústrias americanas de 40 diferentes setores, com objetivo de elencar uma lista dos indicadores de desempenho para a gestão de P\&D mais utilizados em organizações identificadas como de alta maturidade em inovação na época. O resultado é apresentado na tabela a seguir: 
Quadro 2 - Indicadores de desempenho de inovação mais utilizados

\begin{tabular}{|c|c|}
\hline Ranking & Indicador de Desempenho \\
\hline 1 & Qualidade da saída do P\&D \\
\hline 2 & Nível das metas atendidas por unidade de negócio \\
\hline 3 & Quantidade de trabalho realizado dentro do prazo estimado \\
\hline 4 & Nível de eficiência da unidade de negócio \\
\hline 5 & Percentual de projetos concluídos \\
\hline 6 & Percentual de resultados do P\&D adotados pela empresa \\
\hline 7 & Frequência de orçamentos ultrapassados \\
\hline 8 & Número de patentes ou copyrights \\
\hline 9 & Percentual de projetos aprovados \\
\hline 10 & Número de reports técnicos produzidos \\
\hline 11 & Lucratividade da unidade de negócio \\
\hline 12 & Número de artigos apresentados em encontros \\
\hline 13 & Número de recompensas concedidas a profissionais \\
\hline
\end{tabular}

Fonte: Adaptado de Moser (1985).

O debate em relação a indicadores de inovação se seguiu, com estudos apontando pontos fortes e fracos no uso de cada um dos indicadores de inovação estudados por diferentes pesquisadores. Pode-se ilustrar o texto de Tidd, Bessant e Pavitt (2005), que avaliou como a inovação afeta a competitividade da empresa e identificou prós e contras do uso de alguns indicadores na análise, conforme tabela a seguir:

Quadro 3 - Prós e contras de indicadores de inovação selecionados

\begin{tabular}{|c|l|l|}
\hline Avaliação de desempenho & \multicolumn{1}{|c|}{ Forças / Vantagens } & Fraquezas / Desvantagens \\
\hline Indicadores de P\&D & $\begin{array}{l}\text { Dados obtidos das principais } \\
\text { fontes de informação sobre } \\
\text { tecnologia }\end{array}$ & $\begin{array}{l}\text { - Perda de detalhes; } \\
\text { Indicador subestimado em } \\
\text { empresas pequenas ou } \\
\text { específicas }\end{array}$ \\
\hline Indicadores de patentes & $\begin{array}{l}\text { - Dados detalhados obtidos } \\
\text { com provisões de } \\
\text { informação de longo prazo; } \\
\text { Compensa fragilidades das } \\
\text { estatísticas de P\&D }\end{array}$ & $\begin{array}{l}\text { Não considera desigualdades da } \\
\text { indústria }\end{array}$ \\
\hline Inovações significativas & Medidas diretas de saída & $\begin{array}{l}\text { - Custos elevados de coleta de } \\
\text { dados; } \\
\text { Não considera melhorias } \\
\text { incrementais }\end{array}$ \\
\hline
\end{tabular}




\begin{tabular}{|c|l|l|}
\hline Avaliação de desempenho & \multicolumn{1}{|c|}{ Forças / Vantagens } & \multicolumn{1}{|c|}{ Fraquezas / Desvantagens } \\
\hline Surveys de inovação & $\begin{array}{l}\text { - Medidas diretas de saída; } \\
\text { — Cobertura abrangente } \\
\text { criteriosa das variáveis } \\
\text { envolvidas no processo; } \\
\text { Custos elevados de coleta de } \\
\text { dados }\end{array}$ \\
\hline Divulgação de produtos & Focado em comercialização & $\begin{array}{l}\text { Não considera inovaçães em } \\
\text { processos, nem melhorias } \\
\text { incrementais em produtos; } \\
\text { - Facilmente manipuláveis pelo } \\
\text { marketing }\end{array}$ \\
\hline Julgamento de especialistas & $\begin{array}{l}\text { Acesso direto à opinião dos } \\
\text { especialistas }\end{array}$ & $\begin{array}{l}\text { Perda da homogeneidade na } \\
\text { qualificação dos funcionários }\end{array}$ \\
\hline $\begin{array}{l}\text { Dependência da opinião de } \\
\text { especialistas }\end{array}$
\end{tabular}

Fonte: Adaptado de Tidd, Bessant e Pavitt (2005).

Neste momento da evolução da pesquisa em indicadores de inovação, conclui-se, portanto, que não há uma única e "ideal" - ou ótima - medida de inovação. Alguns indicadores se adequam melhor a algumas condições, setores e formas de atuação das empresas. Assim, aumenta-se a importância do desenvolvimento de sistemas de medição de desempenho de inovação para as empresas que se deseje analisar, seja por fins acadêmicos ou por fins de resultado prático. Estes, se bem compreendidos, podem apoiar decisões das empresas como alocação de recursos, priorização de projetos ou comparações de atividades inovadoras para fins específicos.

A partir da construção e desenvolvimento de sistemas de medição de desempenho da inovação, diversos estudos derivaram ao longo do tempo para procurar avaliar o esforço em busca da inovação dentro das empresas e para apoiar a gestão da inovação.

Segundo o quadro teórico de Oliveira (2010), apresentado no início desta seção, uma primeira gama de estudos em relação a sistemas de indicadores de inovação trouxe a visão de sistemas alinhados à lógica de controle e avaliação.

Desta linha de pesquisa, pode-se citar o trabalho de Rubenstein (1957), que recomendou o controle como forma de garantir que a atividade de inovação seja executada dentro do que foi planejado, provendo informação para ações corretivas imediatas, e a avaliação para garantir que resultados alcançados pela inovação estejam dentro do planejado, provendo referência para ações corretivas futuras. 0 modelo proposto pode ser compreendido pelo diagrama a seguir: 
Figura 5 - Controle para execução do plano de inovação

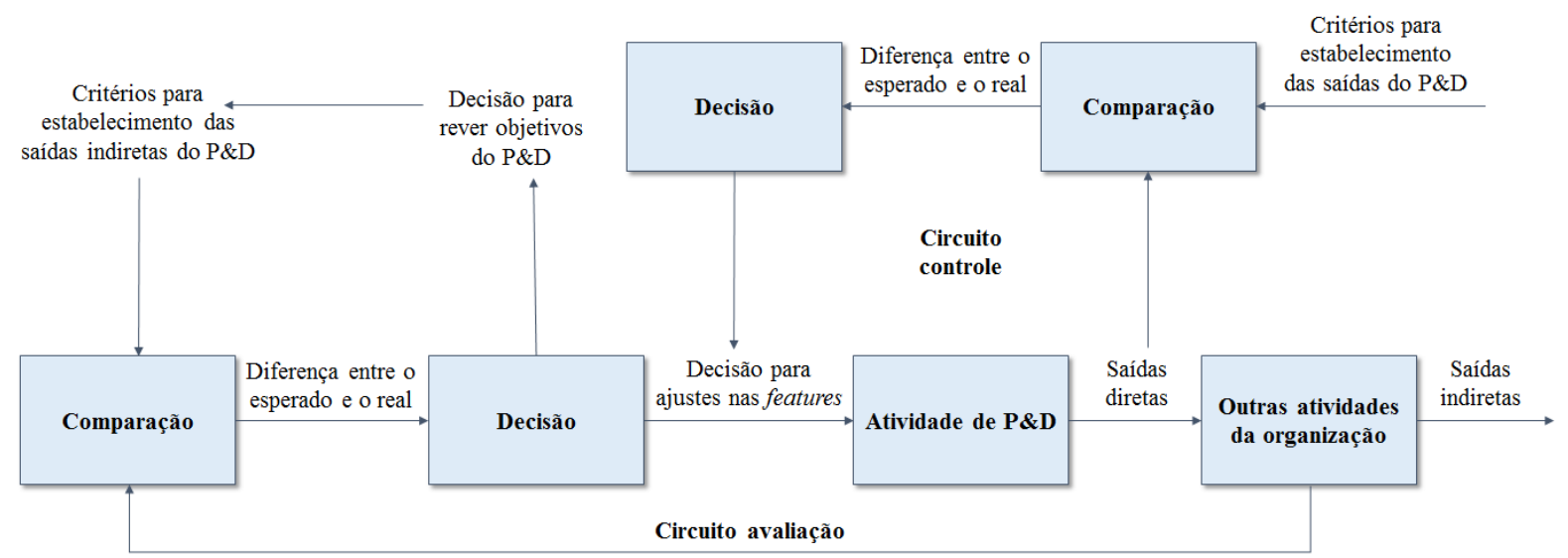

Fonte: Adaptado de Rubenstein (1957).

Uma segunda linha de pesquisa no assunto foi na elaboração de estudos de sistema de medição de desempenho ligados a uma visão processual da inovação. Segundo Oliveira (2010), um dos primeiros artigos elaborados nesta linha foi o de Collier (1977), que propôs um sistema de avaliação em contraposição aos métodos limitados aos indicadores de produtividade, principalmente por não reconhecer as metas estratégicas da organização. Destacou a necessidade de distinção entre produtividade, eficiência e eficácia em diferentes estágios da inovação, desde a geração de ideias até os objetivos financeiros relacionados à inovação.

Brown e Svenson (1988) trouxeram o conceito de inovação como sistema que deveria ser medido em diferentes etapas do processo em relação a diferentes dimensões. Esta abordagem inspirou os primeiros modelos de auditoria de inovação (audits). Esta visão de processo pode ser observada pelo modelo a seguir:

Figura 6 - Inovação como sistema

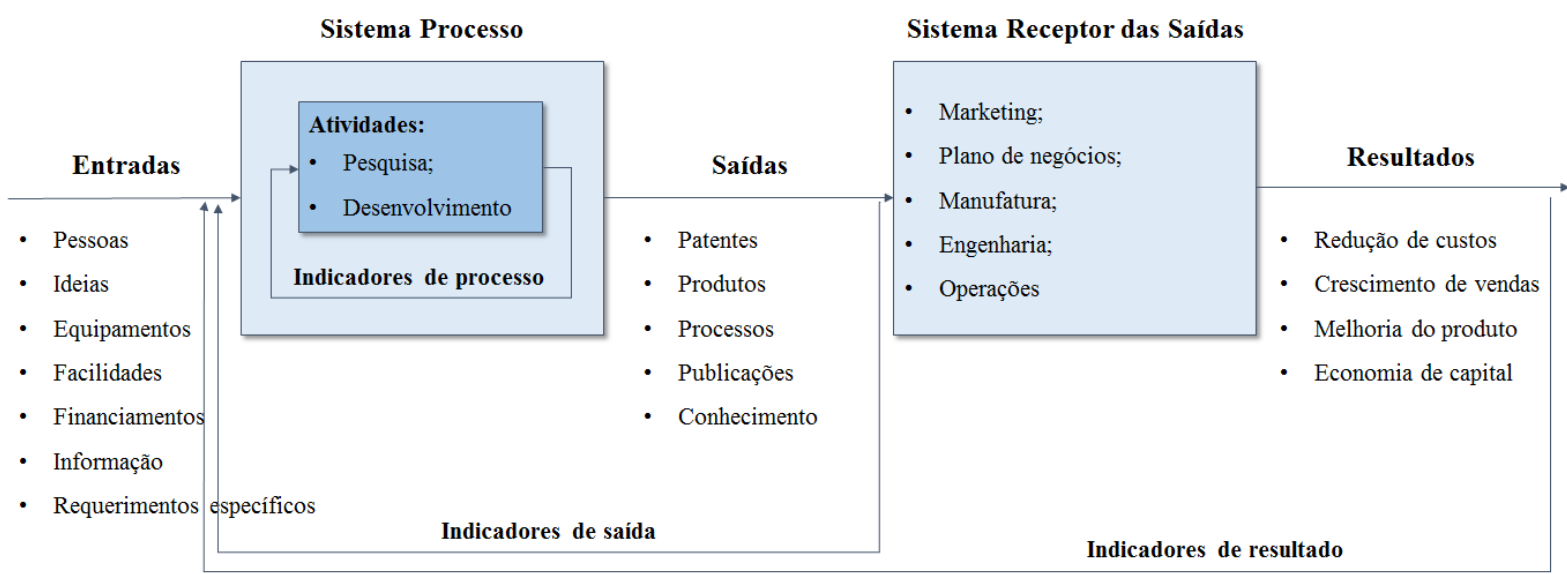

Fonte: Adaptado de Brown e Svenson (1988). 
Tidd, Bessant e Pavitt (2005) pontuam o processo de inovação como sendo desencadeado a partir do esforço e do uso dos recursos para transformar ideias e capacidades em produtos de aceitação pelo mercado. Também inclui o conceito de aprendizado de Porter (1990) e a estrutura de incentivos para que o objetivo seja atingido. Seu processo pode ser descrito pela seguinte ilustração do processo:

Figura 7 - Processo básico de inovação

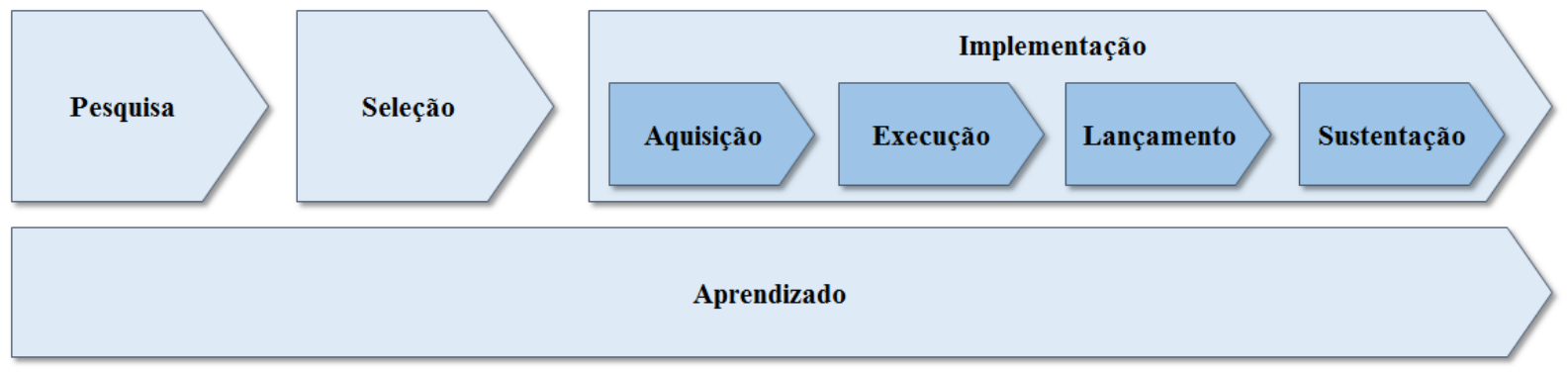

Fonte: Adaptado de Tidd, Bessant e Pavitt (2005).

Também nesta linha de pesquisa surge o famoso modelo de Cooper (1990), desenvolvido para fins de seleção e avaliação de projetos. Com a ideia dos stagegates, traz um processo calcado em etapas e marcos para avaliação desde a geração de ideias até a difusão para o mercado.

Figura 8 - Modelo dos stage-gates

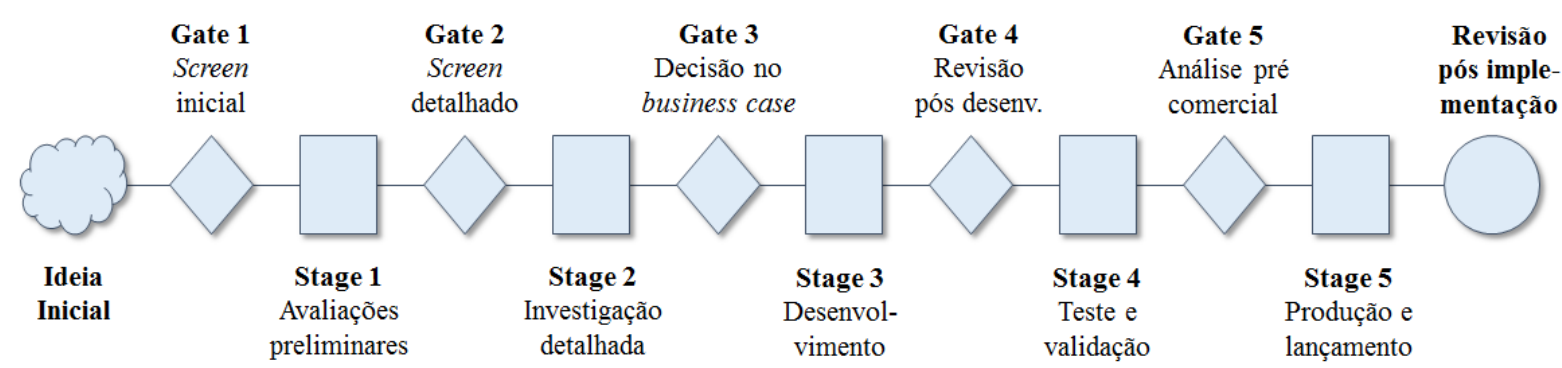

Fonte: Adaptado de Cooper (1990)

Segundo Oliveira (2010), embora Cooper não tenha sugerido indicadores, uma vez que pretendeu ter um modelo genérico e generalizável, os marcos pressupõem uma lógica de indicadores para suportar a decisão. Em seu texto, dá exemplos de sistemas de medição e avaliação que poderiam ser utilizados: 
- Análise de mercado: tamanho, crescimento, segmentação, tendências;

- Análise competitiva: market share, players;

- Reação de cliente: reação para conceito, sensibilidades a preço;

- Avaliação de desenvolvimento: viabilidade, rota, tempos e despesas;

- Avaliação de produção: viabilidade, tempos e despesas;

- Legal: avaliação inicial de questões legais;

- Financeiro: payback, TIR.

Outro grupo de pesquisadores elaborou estudos diversos, com sistemas de medição complexos que envolvem elementos multidimensionais da inovação. Aqui há a grande gama de estudos mais recentes e não há uma uniformidade de ações, pois o mote é identificar sistemas de medição e avaliação de desempenho sob diferentes perspectivas.

Tipping e Zeffren (1995), por exemplo, desenvolveram o modelo da Technology Value Pyramid (TVP), que avalia o valor estratégico da inovação de uma empresa. Estão incluídos no modelo cinco camadas da pirâmide que consistem em: processos de pesquisa e desenvolvimento, valor de ativos tecnológicos, integração com negócio, desenvolvimento de portfólio e criação de valor. A pirâmide reflete diversos níveis de medição e avaliação, desde o estratégico até atividades mais operacionais. Em seu estudo, sugere trinta e três indicadores de desempenho que estão relacionados com cada uma das camadas da pirâmide.

Kerssens-van Drongelen e Cook (1997) sugeriram um método correlacionado com o Balanced Scorecard de Kaplan e Norton, em que tratam das dimensões de alinhamento estratégico e os demais indicadores deste modelo.

Outra ferramenta importante nessa linha de pesquisa, relativamente recente, é o Pentatlo da Inovação de Goffin e Mitchell (2005), em que além das cinco camadas da inovação (pentatlo), propuseram um instrumento de auditoria baseado em seu modelo, que apoia a gestão da inovação por meio de um conjunto de elementos quantitativos e qualitativos. (O framework foi apresentado na seção 2.2, como um dos processos de inovação de referência na literatura.) 


\subsection{AUDITORIAS DE INOVAÇÃO}

Especificamente os estudos que tratam ou propõem modelos de auditoria de inovação têm importância substancial para a pesquisa em questão, uma vez que esta pretende identificar quais indicadores são usualmente utilizados e quais são necessários para um modelo satisfatório de gestão, avaliação e acompanhamento. A revisão dos modelos de auditorias (audits) proveem maturidade e embasamento para a construção dos instrumentos e protocolos de pesquisa, auxiliando inclusive como check-lists para dimensões e elementos a serem tratados.

As auditorias de inovação têm o propósito descobrir as forças e fraquezas exatas dos processos e das práticas de inovação de uma organização, de modo a determinar as melhores maneiras de aumentar seu desempenho (KARLSSON; JOHNSSON; BACKSTROM, 2010). A revisão de literatura indica o esforço de alguns pesquisadores no desenvolvimento de modelos de auditoria de inovação. Pode-se citar, por exemplo, os seguintes trabalhos:

- Chiesa, Coughlan e Voss (1996) propuseram um modelo de auditoria da inovação que contempla quatro processos centrais: a identificação de conceitos de novos produtos, o desenvolvimento de produtos, o processo de inovação e o desenvolvimento e gestão da tecnologia. No detalhamento, são consideradas variáveis como recursos, sistemas, ferramentas e liderança;

Quadro 4 - Dimensões de desempenho

\begin{tabular}{|l|l|l|}
\hline \multicolumn{4}{|c|}{ Dimensões de desempenho } \\
\hline $\begin{array}{l}\text { Geração de conceito: novas ideias, novos } \\
\text { produtos, satisfação do cliente, ciclo de vida do } \\
\text { produto }\end{array}$ & $\begin{array}{l}\text { Liderança: profissionais envolvidos com o } \\
\text { processo inovador, comunicação das iniciativas } \\
\text { e projetos }\end{array}$ \\
\hline $\begin{array}{l}\text { Desenvolvimento de produto: time to market, } \\
\text { desempenho do produto, desempenho do design }\end{array}$ & $\begin{array}{l}\text { Recursos: recursos humanos, recursos } \\
\text { financeiros, projetos atrasados por falta de } \\
\text { recursos }\end{array}$ \\
\hline $\begin{array}{l}\text { Inovação de processo: eficácia, velocidade, } \\
\text { custo de desenvolvimento, melhoria contínua }\end{array}$ & $\begin{array}{l}\text { Sistemas e ferramentas: número de engenheiros } \\
\text { e designers, processos certificados, funcionários } \\
\text { treinados }\end{array}$ \\
\hline $\begin{array}{l}\text { Aquisição tecnológica: tecnologias, patentes, } \\
\text { licenças, desempenho de P\&D }\end{array}$ & & \\
\hline
\end{tabular}

Fonte: Adaptado de Chiesa et al (1996). 
- Amidon Rogers (1996) apresenta um modelo similar ao de Chiesa, Coughlan e Voss (1996), porém calcado em cinco domínios de gestão da inovação: desempenho, estrutura, pessoas, processos e tecnologia;

- Goffin e Mitchell (2005) desenvolvem um modelo de auditoria relacionado às dimensões propostas em seu pentatlo da inovação, que envolvem: estratégia de inovação, geração de ideias, priorização, implementação, pessoas e organização, atrelando-as a medidas de entrada, saída e de execução do processo inovador;

Quadro 5 - Mensuração de desempenho dos processos

\begin{tabular}{|c|c|c|}
\hline Medidas de entrada & Medidas de processo & Medidas de saída \\
\hline $\begin{array}{l}\text { Financeiras: percentual do } \\
\text { faturamento investido em } P \& D \text {, } \\
\text { investimentos em aquisição de } \\
\text { tecnologias, projetos atrasados } \\
\text { ou cancelados por falta de } \\
\text { recursos }\end{array}$ & $\begin{array}{lll}\text { Financeiras: custo médio dos } \\
\text { projetos, economia por } \\
\text { terceirização de parte do } \\
\text { processo }\end{array}$ & $\begin{array}{l}\text { Financeiras: faturamento } \\
\text { proveniente de novos produtos, } \\
\text { melhoria de qualidade } \\
\text { proveniente de inovações, } \mathrm{ROI}\end{array}$ \\
\hline $\begin{array}{l}\text { Perspectiva do cliente: mix de } \\
\text { projetos por direcionadores } \\
\text { estratégicos }\end{array}$ & $\begin{array}{l}\text { Eficiência do processo: ponto } \\
\text { de equilíbrio, horas trabalhadas } \\
\text { por projeto, time to market, } \\
\text { número de patentes, } \\
\text { funcionários envolvidos }\end{array}$ & $\begin{array}{l}\text { Perspectiva do cliente: número } \\
\text { de novos produtos comparados } \\
\text { aos concorrentes, velocidade } \\
\text { de introdução de novos } \\
\text { produtos no mercado } \\
\text { (percepção de novidade e } \\
\text { inovação), índices de satisfação } \\
\text { do consumidor }\end{array}$ \\
\hline \multirow[t]{2}{*}{$\begin{array}{lrr}\text { Recursos: } & \text { número } & \text { de } \\
\text { funcionários } & \text { envolvidos, } \\
\text { funcionários } & \text { treinados, ideias } \\
\text { geradas, eficiência r no } \\
\text { relacionamento externo à } \\
\text { empresa } & & \\
\text { ema } & & \end{array}$} & $\begin{array}{l}\text { Aprendizado: realização de pós } \\
\text { projeto, melhorias nos } \\
\text { processos de inovação }\end{array}$ & \\
\hline & $\begin{array}{l}\text { Medidas de serviço: contato } \\
\text { com o cliente, satisfação da } \\
\text { equipe de apoio, lucro e custo } \\
\text { por cliente }\end{array}$ & \\
\hline
\end{tabular}

Fonte: Adaptado de Goffin e Mitchell (2005).

- Adams, Bessant e Phelps (2006), a partir de revisão de literatura em modelos de gestão de inovação e auditorias, propõem uma ferramenta para avaliação 
do desempenho considerando sete dimensões: entradas, gestão de conhecimento, estratégia de inovação, organização e cultura, gestão de portfólio, gestão de projetos e comercialização;

Quadro 6 - Ferramenta de avaliação para gestão da inovação

\begin{tabular}{|c|c|}
\hline Dimensões do modelo & Elementos a serem medidos \\
\hline Entradas & $\begin{array}{ll}\text { - } & \text { Pessoas } \\
\text { - } & \text { Recursos físicos e financeiros } \\
\text { - } & \text { Ferramentas }\end{array}$ \\
\hline Gestão de conhecimento & $\begin{array}{ll}\text { - } & \text { Geração de ideias } \\
\text { - } & \text { Repositório de conhecimento } \\
\text { - } & \text { Fluxos de informação }\end{array}$ \\
\hline Estratégia de inovação & $\begin{array}{l}\text { - } \quad \text { Orientação estratégica } \\
\text { - } \quad \text { Liderança estratégica }\end{array}$ \\
\hline Organização e cultura & $\begin{array}{ll}\text { - } & \text { Cultura } \\
\text { - } & \text { Estrutura }\end{array}$ \\
\hline Gestão de portfólio & $\begin{array}{l}\text { - Balanceamento risco-retorno } \\
\text { - Uso de ferramentas de otimização }\end{array}$ \\
\hline Gestão de projetos & 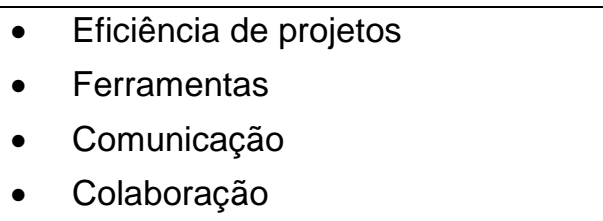 \\
\hline Comercialização & $\begin{array}{ll}\text { - } & \text { Pesquisa de mercado } \\
\text { - } & \text { Teste de mercado } \\
\text { - } & \text { Marketing e vendas }\end{array}$ \\
\hline
\end{tabular}

Fonte: Adaptado de Adams et al (2006).

- Moultrie, Clarkson e Probert (2007) constroem e testam um modelo de auditoria relacionado ao desenvolvimento de novos produtos para pequenas e médias empresas. As dimensões utilizadas em sua ferramenta são: geração de projetos, captura de requisitos, design de conceito, implementação e gestão de projetos.

\subsection{GESTÃO DA INOVAÇÃO EM PEQUENAS E MÉDIAS EMPRESAS}

A presente seção é necessária para destacar os principais elementos de distinção entre a gestão da inovação em pequenas e médias empresas, destacando-as das grandes empresas, em que a literatura é mais vasta. 
Segundo Audretsch et al. (2009), as pequenas empresas contribuem significantemente com inovação tecnológica e crescimento econômico e, portanto, devem ser objeto de estudo. Para elas, a inovação em produto, foco desta pesquisa, é um orientador importante de desempenho e crescimento em pequenas empresas (ROSENBUSCH; BRINCKMANN; BAUSCH, 2011).

Para Moultrie, Clarkson e Probert (2007), a maioria da pesquisa em gestão da inovação para produtos foca basicamente em grandes empresas, ou falha em distinguir grandes e pequenas empresas.

Ao contrário das grandes empresas, as pequenas e médias empresas dependem principalmente do conhecimento do presidente - muitas vezes o proprietário - para inovar (ANDRIES; CZARNITZKI, 2014). Na visão de Klass et al. (2010), líderes desse perfil de empresas raramente envolvem os empregados em atividades únicas e valiosas como desenvolver inovações.

Pelo lado positivo, as pequenas e médias empresas contam com maior flexibilidade como vantagem competitiva para inovação (FIEGENBAUM; KARNANI, 1991), tendo menor burocracia associada e um diretor - ou dono - próximo para tomar as decisões necessárias rapidamente. Adicionalmente, a comunicação com colaboradores e clientes tende a ser mais rápida.

A literatura ainda aponta para outras vantagens que as PMEs possuem para inovar, a saber:

- Maior flexibilidade e capacidade de adaptação a mudanças no mercado (ROTHWELL; DOGSON, 1993);

- Podem operar em nichos que apresentam alta taxa de inovação (ROTHWELL; DOGSON, 1993);

- Ambiente de pequenas empresas induz a uma maior motivação dos empregados em desenvolver a produtividade e a competitividade através de inovações (JULIEN, 1993).

Por outro lado, os recursos e as capacidades em gestão são mais limitados (MOULTRIE; CLARKSON; PROBERT, 2007), podendo se destacar aquelas relacionadas à organização e ao marketing, que tendem a apresentar lacunas quando 
comparadas às grandes empresas (VAN DE VRANDE et al., 2009). Adicionalmente, possuem redes de relacionamento mais fracas normalmente (SRINIVASAN et al., 2002). Essas características criam desafios para os esforços de inovação de produtos em pequenas e médias empresas.

Por estes motivos, pequenas e médias empresas tipicamente trabalham em poucos projetos de inovação de produtos ao mesmo tempo, muitas vezes em somente um, ou, às vezes, nenhum (LAFORET, 2008). Por consequência, a experiência em gestão de inovação é geralmente limitada.

Há diferenças em execução de atividades do processo de inovação de produtos em pequenas e médias empresas. É pouco comum, por exemplo, evidenciar processos estruturados de desenvolvimento de novos produtos neste perfil (MARCH-CHORDA; GUNASEKARAN; LLORIA-ARAMBURO, 2002; SCOZZI; GARAVELLI; CROWSTON, 2005). Moultrie, Clarkson e Probert (2007) apontam outro exemplo: a pesquisa de mercado e o posicionamento, identificados como necessários para serem executados logo no início do processo em grandes empresas, geralmente não são realizados ou são feitos de modo incipiente.

Portanto, a pesquisa em inovação de produtos deve diferenciar o porte da empresa, ao invés de prescrever as melhores práticas das empresas grandes para as pequenas. Para Berends et al. (2014), um modelo de indicadores falharia ao pressupor uma lógica causal baseada nas melhores práticas de grandes empresas, ignorando as restrições de uma pequena ou média empresa, como tempo, pessoas e recursos financeiros.

\subsection{SIINTESE}

Embora diversos conceitos e estudos tenham sido apresentados neste capítulo, é importante destacar o quadro referencial utilizado para elaboração desta pesquisa.

Com o propósito de focar nas inovações incrementais orientadas ao desenvolvimento de novos produtos, utilizou-se das características do quadro conceitual de Leifer et al. (2000), apresentado na seção 2.1, para identificação dessas na pesquisa de campo. 
A inovação foi abordada como processo, e não função, pela preocupação estar no sequenciamento das etapas de desenvolvimento de produtos e no entendimento das variáveis de entrada, processo e saída em cada uma das etapas. Adotou-se o modelo conceitual de Hansen e Birkinshaw (2007), apresentado na seção 2.2, que traduz o processo de inovação em geração de ideias, conversão e difusão por ser de simples entendimento e aplicação ao perfil das PMEs estudadas e refletir os processos observados em campo nestas empresas. Embora o "pentatlo da inovação" de Goffin e Mitchell (2005) seja mais completo conceitualmente, as dimensões de estratégia de inovação e pessoas e organização são de tradução complexa em termos de indicadores facilmente implementáveis.

Para desenvolvimento de sistema de indicadores mais adequado para as PMEs analisadas, utilizou-se como base os modelos de auditoria de inovação propostos por Goffin e Mitchell (2005) e Adams, Bessant e Phelps (2006). O primeiro por oferecer uma lista exaustiva de indicadores relacionando-os às etapas do processo de inovação. O segundo, por ter realizado revisão bibliográfica de modelos pregressos e sintetizá-los em dimensões a serem consideradas para mensuração do desempenho inovador.

Ainda, utilizou-se dos aprendizados da literatura existente em gestão da inovação em PMEs, apresentada na seção 2.6, por destacar as peculiaridades e pontos de atenção na condução de pesquisa com organizações deste porte.

O capítulo a seguir traz a metodologia empregada, apresentando a seleção da abordagem por estudos de caso e discorrendo acerca do processo metodológico de pesquisa. Conforme explicitado adiante, esta foi conduzida em três fases, partindo de compreensão inicial da gestão da inovação em 21 empresas do perfil estudado e evoluindo até o desenvolvimento e teste da ferramenta em três empresas selecionadas. 


\section{METODOLOGIA}

Este capítulo aborda a metodologia de pesquisa, fundamental para o estudo de caráter acadêmico. Na seção 3.1 são apresentadas as motivações para a escolha da abordagem por estudos de caso. Na seção 3.2, discorre-se sobre o processo metodológico empregado, baseado no proposto por Eisenhardt (1989). Ainda, tratase da divisão da pesquisa de campo em três fases, em que são compreendidos: (i) aspectos gerais da gestão da inovação em PMEs industriais tradicionais, (ii) processos de inovação e sistemas de mensuração de desempenho utilizados e, (iii) aderência da ferramenta desenvolvida nas empresas do perfil estudado.

\subsection{SELEÇÃO DE ABORDAGEM DE PESQUISA}

Yin (2003) aponta quatro critérios para que a abordagem de pesquisa seja selecionada:

- Adequação do método aos conceitos envolvidos;

- Adequação aos objetivos da pesquisa;

- Validade de construção, interna e externa;

- Confiabilidade do método.

A adequação do método aos conceitos envolvidos está calcada no conhecimento do pesquisador em relação aos assuntos da pesquisa e às informações obtidas junto às empresas entrevistadas. Desta forma, a ausência do pesquisador comprometeria a qualidade dos dados e, por consequência, do estudo como um todo.

A adequação aos objetivos da pesquisa tem relação com a eficácia e eficiência, levando em consideração se o método selecionado suporta a finalidade do estudo sob estes dois aspectos.

A validade de construção está atrelada à mensuração ou avaliação das medidas corretas para o constructo e para os conceitos estudados, de modo que as informações coletadas sejam representativas do objeto do trabalho. A validade interna se refere ao relacionamento entre as dimensões e variáveis selecionadas para o estudo, sendo que a adição de itens não pertencentes ao sistema, ou a subtração - 
ou não consideração - de itens importantes ao modelo conceitual podem resultar em conclusões inverídicas. A validade externa se trata da possibilidade de generalizar os resultados encontrados, seja estatística ou analiticamente.

Por fim, a confiabilidade do método garante que a pesquisa possa ser reproduzida posteriormente, de modo que sejam alcançados aproximadamente os mesmos resultados caso as premissas do estudo e da metodologia sejam mimetizadas sem alterações substanciais.

A tabela a seguir apresenta um guia para orientar a seleção do método de procedimento da pesquisa, tendo como referência as suas características e a adequação dos métodos.

Quadro 7 - Critérios para escolha do método de pesquisa

\begin{tabular}{|c|c|c|c|c|}
\hline Características da Pesquisa & $\begin{array}{c}\text { Pesquisa } \\
\text { Experimental }\end{array}$ & $\begin{array}{c}\text { Pesquisa de } \\
\text { Avaliação }\end{array}$ & $\begin{array}{c}\text { Estudo de } \\
\text { Caso }\end{array}$ & $\begin{array}{l}\text { Pesquisa- } \\
\text { Ação }\end{array}$ \\
\hline $\begin{array}{l}\text { Presença do pesquisador na } \\
\text { coleta de dados }\end{array}$ & Possível & $\begin{array}{l}\text { Pouco } \\
\text { comum }\end{array}$ & Comum & Comum \\
\hline Construção de Teoria & Possível & $\begin{array}{l}\text { Pouco } \\
\text { comum }\end{array}$ & Adequado & Possível \\
\hline Tamanho de amostra pequeno & Possível & $\begin{array}{l}\text { Pouco } \\
\text { Comum }\end{array}$ & Comum & Comum \\
\hline Variáveis difíceis de quantificar & Possível & Possível & Possível & Possível \\
\hline Medidas perceptíveis & Possível & Possível & Possível & Possível \\
\hline Fronteiras não pré-definidas & $\begin{array}{l}\text { Pouco } \\
\text { Comum }\end{array}$ & Difícil & Adequado & Possível \\
\hline $\begin{array}{l}\text { Elucidar causalidade entre as } \\
\text { variáveis }\end{array}$ & Adequado & $\begin{array}{l}\text { Pouco } \\
\text { Comum }\end{array}$ & Adequado & Possível \\
\hline $\begin{array}{l}\text { Necessidade de responder à } \\
\text { pergunta "como" }\end{array}$ & Possível & Difícil & Adequado & Possível \\
\hline $\begin{array}{l}\text { Compreensão profunda do } \\
\text { processo de decisão }\end{array}$ & Difícil & Difícil & Adequado & Possível \\
\hline $\begin{array}{l}\text { Participação não "ativa" do } \\
\text { pesquisador }\end{array}$ & Possível & Possível & Possível & Impossível \\
\hline $\begin{array}{l}\text { Ausência de controle sobre as } \\
\text { variáveis }\end{array}$ & Difícil & Possível & Possível & Possível \\
\hline
\end{tabular}

Fonte: Adaptado de Yin (2003).

A análise da tabela demonstra que o estudo de caso é um método adequado às características desta pesquisa. Isso se deve principalmente aos critérios evidenciados: presença do pesquisador na coleta de dados, tamanho de amostra relativamente pequeno, variáveis difíceis de quantificar, fronteiras não pré-definidas e ausência de controle sobre as variáveis. 
Adicionalmente, conforme exposto por Eisenhardt (1989), o processo de pesquisa indutivo, orientado por casos, é especialmente apropriado para novos tópicos ou quando se conhece pouco sobre determinado fenômeno ou ainda quando as perspectivas atuais da pesquisa parecem inadequadas para determinados casos observados empiricamente. Também é recomendada para casos em que não há literatura prévia ou evidências empíricas suficientes em estudos. É adequada para estágios iniciais de pesquisa em um tema ou para trazer novas ideias a tópicos de pesquisa já estudados. Tendo em vista o objetivo de aprofundar os aspectos da mensuração de desempenho da inovação e a necessidade de estudar qualitativamente o assunto, trazendo novas ideias à pesquisa neste tema em PMEs industriais tradicionais, esta abordagem se mostra recomendada.

\subsection{METODOLOGIA UTILIZADA: ESTUDOS DE CASO}

Estudos de caso podem ser utilizados para diversos fins, como prover descrição (KIDDER, 1982), testar teoria (ANDERSON, 1983; PINFIELD, 1986) ou gerar teoria (HARRIS; SUTTON, 1986; GERSICK, 1988).

Segundo Eisenhardt (1989), ainda que esta abordagem seja criticada pelo processo ser limitado pelas pré-concepções do pesquisador, o oposto também é verdade. A justaposição de realidades conflitantes auxilia a alterar a percepção inicial sobre o tema, aumentando o potencial de gerar novos aprendizados e teorias. Por outro lado, o cuidado deve ser redobrado em focar nas questões principais de pesquisa e evitar a captura de informações em excesso e desnecessárias ao trabalho.

Embora o objetivo desta dissertação não seja construir teoria, o processo metodológico foi norteado pelas etapas de pesquisa utilizando casos propostas por Eisenhardt (1989). O quadro a seguir sintetiza as etapas e as atividades prescritas pela literatura (primeira e segunda colunas), enquanto que a terceira coluna sintetiza as definições que serão utilizadas especificamente nesta pesquisa e serão explicitadas no texto seguinte ao quadro. 
Quadro 8 - Processo de pesquisa proposto para o estudo

\begin{tabular}{|c|c|c|}
\hline Etapas & $\begin{array}{c}\text { Atividades prescritas pela } \\
\text { literatura }\end{array}$ & $\begin{array}{c}\text { Definições utilizadas para esta } \\
\text { pesquisa }\end{array}$ \\
\hline 1) Inicial & $\begin{array}{l}\text { Definição da questão de } \\
\text { pesquisa } \\
\text { - Constructos de referência }\end{array}$ & $\begin{array}{l}\text { - Abordada na seção } 1 \\
\text { (Questão central: Quais os } \\
\text { indicadores de inovação mais } \\
\text { adequados para PMEs } \\
\text { industriais tradicionais, de } \\
\text { setores de média ou baixa } \\
\text { intensidade tecnológica?) } \\
\text { - Abordados na seção } 2 \\
\text { - Pesquisa estruturada em três } \\
\text { fases de campo }\end{array}$ \\
\hline 2) Seleção de casos & $\begin{array}{l}\text { - Definição da população } \\
\text { - Amostragem teórica }\end{array}$ & 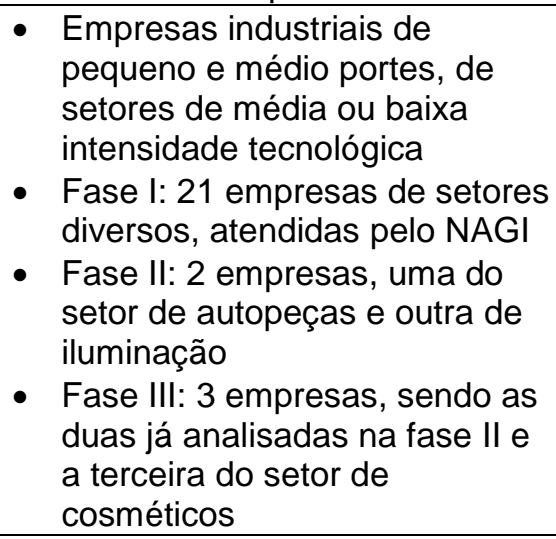 \\
\hline $\begin{array}{l}\text { 3) Criação de } \\
\text { instrumentos e } \\
\text { protocolos }\end{array}$ & $\begin{array}{l}\text { - Definição dos métodos de coleta } \\
\text { de dados } \\
\text { - Combinação de dados } \\
\text { quantitativos e qualitativos }\end{array}$ & $\begin{array}{l}\text { - Fase I: combinação de } \\
\text { questionário remoto, } \\
\text { entrevistas e observações } \\
\text { presenciais voltados a } \\
\text { compreensões iniciais de } \\
\text { gestão da inovação } \\
\text { - Fase II: entrevistas e } \\
\text { observações presenciais } \\
\text { voltadas ao processo de } \\
\text { inovação, sua gestão e } \\
\text { indicadores utilizados } \\
\text { Fase III: entrevistas e } \\
\text { observações presenciais para } \\
\text { verificação de aderência da } \\
\text { ferramenta desenvolvida }\end{array}$ \\
\hline 4) Campo & $\begin{array}{l}\text { - Sobreposição de coleta de } \\
\text { dados e análises } \\
\text { - Métodos de coleta flexíveis e } \\
\text { oportunísticos }\end{array}$ & $\begin{array}{l}\text { - Anotações de campo, atas de } \\
\text { reunião e sistematização dos } \\
\text { aprendizados ao final do dia } \\
\text { - } \text { Pequenas revisões do } \\
\text { questionário e das entrevistas } \\
\text { durante o estudo dos casos } \\
\text { para aprimoramento } \\
\text { Aplicação do modelo } \\
\text { desenvolvido nas empresas } \\
\text { objeto de estudo }\end{array}$ \\
\hline 5) Análise dos dados & $\begin{array}{l}\text { - Análise "de dentro" dos casos } \\
\text { - Busca de padrões a partir do } \\
\text { cruzamento dos casos }\end{array}$ & $\begin{array}{l}\text { - Sistematização das } \\
\text { informações coletadas e } \\
\text { identificação de eventuais } \\
\text { padrões } \\
\text { - } \\
\text { Aprendizados em campo são } \\
\text { confrontados com a literatura } \\
\text { utilizada no referencial teórico }\end{array}$ \\
\hline
\end{tabular}




\begin{tabular}{|c|c|c|}
\hline Etapas & $\begin{array}{c}\text { Atividades prescritas pela } \\
\text { literatura }\end{array}$ & $\begin{array}{c}\text { Definições utilizadas para esta } \\
\text { pesquisa }\end{array}$ \\
\hline $\begin{array}{l}\text { 6) Elaboração de } \\
\text { hipóteses }\end{array}$ & $\begin{array}{l}\text { - Tabulação das evidências para } \\
\text { cada constructo } \\
\text { - Lógica de replicação através } \\
\text { dos casos } \\
\text { - Buscar dos "porquês" para as } \\
\text { relações encontradas }\end{array}$ & $\begin{array}{l}\text { - Atividades não foram aplicadas } \\
\text { a esta pesquisa }\end{array}$ \\
\hline $\begin{array}{l}\text { 7) Comparação com a } \\
\text { literatura }\end{array}$ & $\begin{array}{l}\text { - Comparação com literatura } \\
\text { conflitante } \\
\text { - Comparação com literatura } \\
\text { similar }\end{array}$ & $\begin{array}{l}\text { - Comparação com textos } \\
\text { relacionados a sistemas de } \\
\text { mensuração de desempenho e } \\
\text { indicadores de inovação } \\
\text { descritos no referencial teórico }\end{array}$ \\
\hline 8) Encerramento & - Saturação teórica (se possível) & $\begin{array}{l}\text { A fase III se encerra com três } \\
\text { objetos de estudo disponíveis } \\
\text { até a finalização da pesquisa. } \\
\text { Entende-se que este número } \\
\text { foi suficiente para o propósito } \\
\text { desta dissertação }\end{array}$ \\
\hline
\end{tabular}

Fonte: Adaptado de Eisenhardt (1989).

\subsubsection{Etapa inicial}

A definição da questão de pesquisa norteia os esforços e orienta quando aos tipos de dados que devem ser coletados.

Conforme apresentado na Introdução deste documento (seção 1), a questão central de pesquisa da futura dissertação é: "Quais os indicadores de inovação mais adequados para PMEs industriais tradicionais, de setores de média ou baixa intensidade tecnológica?". Adicionalmente, pretende-se que sejam respondidas as seguintes perguntas:

- Quais sistemas de gestão e indicadores de inovação são atualmente utilizados por estas empresas?

- Quais métricas poderiam auxiliar estas empresas a inovar regularmente?

A especificação dos constructos permite aos pesquisadores medi-los mais precisamente, testá-los e sedimentar novas teorias - ou parte delas - com maior embasamento teórico.

Os constructos desta pesquisa foram apresentados na seção anterior de revisão bibliográfica (seção 2) e auxiliarão na seleção de casos e na especificação de 
dimensões e variáveis iniciais para o estudo, úteis na criação dos instrumentos e protocolos de pesquisa, na análise dos dados e na elaboração de hipóteses.

Contudo, é importante ressaltar que em pesquisa com estudos de caso, tanto a definição da questão de pesquisa quanto os constructos de referência são tentativos, uma vez que podem sofrer alteração durante a pesquisa de abordagem qualitativa.

Ainda na etapa inicial, pode-se definir a estratégia de realização da pesquisa em fases, nas quais a questão central vai sendo construída progressivamente. Cada uma das fases, que inclui seleção de casos, criação de instrumentos e protocolos, campo e análise de dados, deve ter um objetivo específico que vai ao encontro da questão central. Podem ser utilizados objetos de pesquisa distintos em cada uma das fases.

A pesquisa realizada está estruturada em três fases, conforme figura a seguir:

Figura 9 - Fases da pesquisa

Compreensão inicial
ComE I:

Fonte: Elaboração própria.

A fase I, caracterizada pela compreensão de aspectos gerais da gestão da inovação em pequenas e médias indústrias tradicionais, foi conduzida junto a empresas selecionadas atendidas pelo Núcleo de Apoio de Gestão à Inovação (NAGI), detalhado na próxima seção.

A fase II, conduzida a partir de dois estudos de caso, teve como objetivo a compreensão do processo de inovação e sua gestão, além de identificar a utilização de sistemas de gestão e indicadores utilizados por estas PMEs.

Por fim, a fase III objetivou a construção de ferramenta para gestão de inovação, a partir dos aprendizados das fases I e II e de indicadores previstos na literatura, e sua posterior verificação de aderência junto a PMEs selecionadas. 


\subsubsection{Seleção de casos}

Antes da seleção dos casos propriamente dita, a definição de população a ser estudada é crucial, uma vez que define os limites da pesquisa e orienta quanto ao grau de generalização que pode ser obtido dos aprendizados dos casos e de uma eventual futura teoria (EISENHARDT, 1989).

Outro ponto importante é a definição da amostra, que deve ser teórica, ou seja, os casos devem ser escolhidos pelo racional da pesquisa e o que ela propõe a estudar, e não por questões estatísticas (GLASER; STRAUSS, 1967). Devem preencher categorias teóricas de estudo e prover exemplos de tipos polarizados ou extremos (PETTIGREW, 1988).

Cabe ressaltar que, durante o processo de pesquisa, casos podem ser eventualmente adicionados ou excluídos no decorrer do processo, de modo a se obter a saturação teórica proposta por Eisenhardt (1989), ponto da pesquisa em que o ganho em aprendizados passa a ser incremental ao conhecimento previamente obtido.

Para esta pesquisa, definiu-se como população empresas industriais de pequeno e médio portes estabelecidas, de setores de média ou baixa intensidade tecnológica, com o seguinte perfil:

- Até 500 funcionários, patamar que define o escopo de pequena e média empresa de acordo com a classificação do Serviço de Apoio às Micro e Pequenas Empresas (SEBRAE);

- Faturamento até $\mathrm{R} \$ 90$ milhões por ano, patamar que define o escopo de pequena e média empresa de acordo com o critério do Banco Nacional de Desenvolvimento (BNDES).

Os estudos de caso utilizados foram selecionados a partir do universo de empresas atendidas pelo "Núcleo de Apoio à Gestão da Inovação" da Escola Politécnica da Universidade de São Paulo (NAGI), do qual o pesquisador faz parte e está desenvolvendo a dissertação concomitantemente com a sua execução.

O projeto NAGI é financiado pela Financiadora de Estudos e Projetos (Finep) e executado pelo Laboratório de Gestão da Inovação da Escola Politécnica da 
Universidade de São Paulo (LGI-USP). Mesclando as finalidades de pesquisa acadêmica e consultoria, visa capacitar e apoiar empresas na introdução ou no aprimoramento do sistema de gestão da inovação e insere-se no esforço do país para aumentar a competitividade das empresas brasileiras por meio de maior inovação.

Oitenta empresas foram estudadas e atendidas por pesquisadores e pela equipe do projeto, com três diferentes perfis: nos extremos, startups e empresas maduras em busca de inovação radical, e um terceiro grupo de empresas estabelecidas com foco em inovações incrementais e desenvolvimento de novos produtos. Nesta última categoria, objeto desta pesquisa, estão 21 empresas do segmento industrial de pequeno e médio portes apresentadas na tabela a seguir (nomes omitidos por questão de confidencialidade):

Tabela 1 - Empresas objeto desta pesquisa

\begin{tabular}{|c|c|c|c|c|}
\hline Empresa & Atividade industrial & $\begin{array}{l}\text { Faturamento } \\
\text { médio mensal } \\
\text { (R\$ mil/mês) }\end{array}$ & $\begin{array}{l}\text { Número de } \\
\text { funcionários }\end{array}$ & Mix de produtos \\
\hline 1 & Aramados - setor pet & Até 200 & De 10 a 50 & Entre 20 e 50 \\
\hline 2 & Autopeças & De 1.300 a 7.500 & Mais de 100 & Mais de 50 \\
\hline 3 & Autopeças & De 200 a 1.300 & De 50 a 100 & Mais de 50 \\
\hline 4 & $\begin{array}{l}\text { Carrocerias para } \\
\text { veículos }\end{array}$ & De 200 a 1.300 & De 50 a 100 & Até 10 produtos \\
\hline 5 & Cosméticos & De 1.300 a 7.500 & Mais de 100 & Mais de 50 \\
\hline 6 & Cosméticos & De 1.300 a 7.500 & De 50 a 100 & Mais de 50 \\
\hline 7 & Cosméticos & De 1.300 a 7.500 & De 50 a 100 & Mais de 50 \\
\hline 8 & Embalagens & Até 200 & De 10 a 50 & Até 10 produtos \\
\hline 9 & $\begin{array}{l}\text { Equipamentos de } \\
\text { pintura }\end{array}$ & De 200 a 1.300 & De 10 a 50 & Mais de 50 \\
\hline 10 & $\begin{array}{l}\text { Equipamentos } \\
\text { industriais }\end{array}$ & De 1.300 a 7.500 & De 50 a 100 & Mais de 50 \\
\hline 11 & Iluminação & De 1.300 a 7.500 & De 50 a 100 & Mais de 50 \\
\hline 12 & Joias & De 200 a 1.300 & De 50 a 100 & Mais de 50 \\
\hline 13 & Joias & De 200 a 1.300 & De 10 a 50 & Mais de 50 \\
\hline
\end{tabular}




\begin{tabular}{|l|l|l|l|l|}
\hline Empresa & Atividade industrial & $\begin{array}{c}\text { Faturamento } \\
\text { médio mensal } \\
\mathbf{( R \$} \text { mil/mês) }\end{array}$ & $\begin{array}{c}\text { Número de } \\
\text { funcionários }\end{array}$ & Mix de produtos \\
\hline 14 & Joias & De 200 a 1.300 & De 10 a 50 & Até 10 produtos \\
\hline 15 & Malas especiais & Até 200 & Menos de 10 & Até 10 produtos \\
\hline 16 & $\begin{array}{l}\text { Muletas e artefatos } \\
\text { de metal }\end{array}$ & De 200 a 1.300 & De 10 a 50 & Entre 20 e 50 \\
\hline 17 & Produtos de limpeza & Até 200 & Menos de 10 & Entre 20 e 50 \\
\hline 18 & $\begin{array}{l}\text { Produtos plásticos } \\
\text { para setor pet }\end{array}$ & De 200 a 1.300 & De 10 a 50 & Mais de 50 \\
\hline 19 & Química & De 1.300 a 7.500 & Mais de 100 & Mais de 50 \\
\hline 20 & Vestuário & De 200 a 1.300 & De 50 a 100 & Entre 20 e 50 \\
\hline 21 & Vestuário & Até 200 & De 10 a 50 & Mais de 50 \\
\hline
\end{tabular}

Fonte: Elaboração própria.

Durante o período de execução do NAGI, as empresas foram estudadas por meio de aplicação de questionário remoto, entrevistas e observações presenciais por membros da equipe do projeto. Do ponto de vista da pesquisa acadêmica, o tema gestão de inovação foi trabalhado de modo amplo, reunindo conceitos da literatura e a experiência prévia dos pesquisadores. Foram tratadas questões relativas a indicadores de inovação, mas não somente, pois o NAGl deveria contemplar o interesse de pesquisa dos seus diversos integrantes, além de auxiliar as empresas em suas demandas específicas.

Assim, para esta pesquisa específica, a fase I consistiu na aplicação e na análise dos dados obtidos por questionário remoto das 21 empresas elencadas, em adição a entrevistas e observações presenciais realizadas junto a seis empresas em que autor realizou o acompanhamento: empresas 1, 2, 9, 11, 17 e 18.

Pela limitação da fase I em explorar aspectos mais amplos da gestão da inovação, fez-se necessário a fase II em que foram trabalhados especificamente as questões relacionadas ao processo e a gestão da inovação com foco nos sistemas de avaliação de desempenho e indicadores. Foram selecionados dois casos a partir da lista apresentada das 21 empresas: empresa 2 (autopeças) e empresa 11 (iluminação). A 
escolha foi realizada por elas apresentarem processo contínuo de desenvolvimento de novos produtos, por ter um porte não muito pequeno em relação a funcionários e faturamento e pela facilidade de acesso a colaboradores e informações.

$\mathrm{Na}$ fase III, para verificação de aderência da ferramenta desenvolvida, foram estudados três casos: as mesmas duas empresas da fase II e uma terceira, a empresa 18 (plásticos). Novamente, a seleção foi realizada em empresas que apresentam processos contínuos de desenvolvimento de produtos, que não possuem porte muito pequeno e pela facilidade de acesso a informações e colaboradores.

\subsubsection{Criação de instrumentos e protocolos}

Para a condução da pesquisa, idealmente se deve utilizar múltiplos dados de coleta de dados. Deve-se ressaltar que a pesquisa com estudos de caso podem envolver dados qualitativos, quantitativos, ou ambos (Yin, 2003). O pesquisador não tem papel passivo, podendo perceber a realidade sob a ótica de quem compõe a organização e até mesmo participar dos eventos que são estudados.

Em relação aos instrumentos e protocolos, durante a fase I foi realizada uma combinação de aplicação de questionário e realização de entrevistas semiestruturadas. As fases II e III foram conduzidas mediante entrevistas semiestruturadas. Adicionalmente, documentos foram coletados e utilizados de modo a gerar convergência das informações que foram levantadas. Para as três fases, tevese como base o quadro referencial teórico apresentado na seção 2.7 deste documento para construção dos instrumentos, considerando as questões da pesquisa.

As especificidades de cada uma das três fases são apresentadas a seguir e detalhadas nas seções 4, 5 e 6 desta dissertação:

- Fase I: foi realizada uma combinação de aplicação de questionário remoto nas 21 empresas selecionadas do projeto NAGI, e conduzidas entrevistas presenciais semiestruturadas em 6 empresas (empresas 1, 2, 9, 11, 17 e 18). Os protocolos e instrumentos desta fase foram construídos coletivamente pela equipe do NAGI a partir de revisão da literatura de gestão da inovação e conhecimento prévio dos pesquisadores. As entrevistas ocorreram durante seis 
atendimentos de meio período (quatro horas) em cada uma das empresas, junto aos responsáveis indicados pela função inovação, no ano de 2015. O protocolo e roteiro da fase I são apresentados na seção 4 e no anexo deste documento.

- Fase II: realização de entrevistas semiestruturadas e observações presenciais com foco nas questões de pesquisa deste trabalho em duas empresas selecionadas (empresas 2 e 11). O procedimento adotado permitiu a condução do pesquisador orientado às questões centrais, sem limitar a possibilidade do entrevistado em discutir assuntos considerados importantes para a pesquisa. As entrevistas ocorreram em janeiro de 2017 junto a gerentes responsáveis pelo desenvolvimento de novos produtos nas duas empresas. O protocolo e o roteiro da fase II são apresentados na seção 5 desta dissertação.

- Fase III: após o desenvolvimento da ferramenta, sua aderência foi verificada mediante realização de entrevistas semiestruturadas e observações presenciais em três empresas (empresas 2, 11 e 18). Similarmente à fase anterior, o procedimento adotado permitiu a condução do pesquisador orientado ao tema central do estudo, sem limitar a possibilidade do entrevistado em discutir assuntos considerados relevantes para a pesquisa. As entrevistas ocorreram em abril e maio de 2017 junto aos gerentes responsáveis pelo desenvolvimento de novos produtos e equipe nas três empresas. O protocolo e o roteiro da fase III são apresentados na seção 6 deste documento.

\subsubsection{Campo}

Uma característica marcante da pesquisa com estudos de caso é a frequente sobreposição de coleta e análise de dados (GLASER; STRAUSS, 1967). Durante o processo de pesquisa, também deve haver a flexibilidade para fazer ajustes no processo de coleta de dados enquanto se está em campo, adicionando eventuais pontos no questionário ou durante as entrevistas, por exemplo. Tal medida visa compreender os casos mais profundamente e obter aprendizados mais valiosos, 0 que não deve ser compreendido como assistemático, mas sim uma abordagem oportunística de aprendizado e construção de conhecimento (EISENHARDT, 1989). 
Para a pesquisa em questão, utilizou-se de ferramentas como anotações de campo, atas de reunião e sistematização dos aprendizados ao final de cada dia, de modo que não se perdessem as impressões no momento em que ocorreram. Eventuais adições ou revisões aos questionários e entrevistas foram necessários durante a pesquisa para seu aprimoramento, porém já estão refletidos neste trabalho em sua versão final.

\subsubsection{Análise dos dados}

Segundo Einserhardt (1989), a análise de dados é o ponto central da pesquisa, porém é a parte do processo mais complexa e menos codificada no sentido de haver prescrições estabelecidas. Contudo, a análise "de dentro" dos casos deve ser bem sistematizada e, posteriormente, buscar padrões a partir do cruzamento dos casos, comparando-os em relação a dimensões que façam sentido para a questão central de pesquisa, que podem ser obtidas, por exemplo, por revisão literária ou pela compreensão empírica dos casos. A comparação é importante para eliminar vieses iniciais do pesquisador e destacar evidências que aproximam ou distanciam os casos.

As análises realizadas durante a fase I da pesquisa estão apresentadas na seção 4 deste documento, enquanto as realizadas nas fases II e III estão nas seções 5 e 6, respectivamente. As informações coletadas nas entrevistas são apresentadas de modo a explicitar os processos de gestão de inovação nas empresas e seus sistemas de medição e indicadores utilizados. Posteriormente, os aprendizados em campo são confrontados com a literatura utilizada no referencial teórico desta dissertação.

\subsubsection{Elaboração de hipóteses}

O próximo passo da pesquisa é comparar sistematicamente o quadro emergente com as evidências de cada um dos casos de modo a avaliar quão consistente estão os aprendizados, análises e hipóteses do pesquisador. Os dados devem dialogar com a teoria de modo a criar robustez à pesquisa.

Neste ponto do processo, os constructos são refinados e as evidências sistematizadas de modo a avaliar a consistência dos constructos para cada um dos casos estudados. Após esta fase de replicação, buscam-se os porquês para as relações encontradas. 
Esta etapa foi pouco aplicada à presente dissertação pelo seu propósito, tendo após a análise dos dados, a etapa de comparação com a literatura apresentada no referencial teórico.

\subsubsection{Comparação com a literatura}

A partir dos aprendizados e das hipóteses geradas, estes são comparados com a literatura existente sobre o assunto, tanto as similares e que convergem com os resultados obtidos, quanto com as conflitantes e divergentes.

Para esta pesquisa, foram utilizados os textos relacionados a sistemas de mensuração de desempenho e indicadores de inovação descritas na seção de referencial teórico.

\subsubsection{Encerramento}

Conforme descrito por Eisenhardt (1989), há dois pontos importantes para a finalização da pesquisa:

- Quando parar de adicionar casos à pesquisa;

- Quando parar a iteração entre os dados e a teoria.

Para ambos, a resposta pode ser sintetizada pela saturação teórica, momento em que o aprimoramento incremental da pesquisa é mínimo perante ao esforço, seja em construção de conceitos, constructos, ferramentas, proposições ou teoria. Se possível, o ideal é que a pesquisa possa atingir este ponto.

Para o presente trabalho, a fase III - última fase de campo - se encerra com o estudo de três organizações disponíveis até a finalização da pesquisa. Entende-se que este número foi suficiente para discutir as questões centrais desta dissertação.

Por fim, deve-se destacar que o processo de pesquisa com estudo de casos é muito iterativo, tendo idas e vindas através das fases da pesquisa. Assim, as oito fases do 
processo de pesquisa foram apresentadas sequencialmente apenas para organização do raciocínio. Na prática elas se intercalam até a finalização da pesquisa.

A próxima seção traz a primeira fase da pesquisa de campo, em que se buscou compreender inicialmente os aspectos da gestão da inovação em PMEs industriais estabelecidas de média ou baixa intensidade tecnológica. Para tanto, foram estudadas 21 empresas selecionadas do NAGI para este propósito. 


\section{FASE I- COMPREENSÃO INICIAL}

Conforme apresentado na seção anterior, a fase I visou compreender inicialmente os aspectos da gestão da inovação em PMEs industriais estabelecidas e selecionar de forma mais eficaz os casos para a execução da fase II, que trata de forma mais específica os aspectos relacionados ao processo de inovação e sua gestão, sobretudo ao que tange aos sistemas de medição de desempenho e indicadores.

A fase I foi realizada por meio de combinação de aplicação de questionário remoto nas 21 empresas selecionadas do projeto NAGl, vide seção anterior, e conduzidas entrevistas presenciais semiestruturadas em seis PMEs industriais de setores de média ou baixa intensidade tecnológica.

Os protocolos e instrumentos desta fase foram construídos coletivamente pela equipe do NAGI a partir de revisão da literatura de gestão da inovação e conhecimento prévio dos pesquisadores. Pelo caráter de pesquisa e prático do NAGI, envolvendo diversos temas relacionados à gestão da inovação, a fase I consiste em uma abordagem mais geral e até por isso se fez necessário as fases II e III descritas na metodologia.

O questionário remoto foi aplicado em plataforma virtual após a inscrição das empresas no projeto NAGl. Recomendava-se o preenchimento pelo responsável pela função da inovação da empresa e, caso não existisse, pelo seu principal executivo. $O$ roteiro de pesquisa foi construído com perguntas do tipo múltipla escolha e encontrase no anexo deste documento.

Após preenchimento do questionário, iniciava-se o processo de atendimento e acompanhamento às empresas, ocorrido no ano de 2015. Este atendimento durava, em média, de quatro a seis meses e consistia em no mínimo seis encontros de meio período em cada uma das empresas, necessariamente com o responsável pela função inovação - ou diretor geral. Eventualmente, eram envolvidas mais colaboradores no processo a convite do principal interlocutor.

Concomitantemente a estes atendimentos, o autor conduziu as entrevistas referentes à fase I desta pesquisa, cujos resultados são apresentados neste capítulo. O roteiro foi pautado nas mesmas dimensões e questões do questionário remoto, anexado ao final deste documento. Adicionalmente, eram debatidos os processos de gestão da 
inovação, seus desafios e objetivos quanto a inovação em desenvolvimento de novos produtos, pela finalidade prática do NAGl. Embora neste ponto a discussão se tornasse ampla, o que justificou a necessidade das fases II e III desta pesquisa, foi útil pela aquisição de conhecimento em relação às organizações acompanhadas, o que facilitou a condução das fases de pesquisa subsequentes.

Os aprendizados provenientes da abordagem qualitativa da fase I, apresentados na sequência dos resultados obtidos junto à aplicação do questionário remoto, foram baseados na condução das entrevistas realizadas junto a seis empresas integrantes do NAGI atendidas e acompanhadas pelo autor, a saber:

- Empresa 1 - Aramados para setor pet: fabricante de gaiolas, viveiros, ratoeiras, focinheiras, entre outros;

- Empresa 2 - Autopeças: indústria com processo produtivo calcado em metalurgia do pó para desenvolvimento de peças para segmento automotivo e linha branca;

- Empresa 9 - Equipamentos de pintura: indústria de equipamentos industriais para pintura eletrostática;

- Empresa 11 - lluminação: fabricante de produtos de iluminação para os segmentos de construção e decoração;

- Empresa 17 - Produtos de limpeza: indústria regional de produtos de higiene e limpeza, com fabricação de detergentes, amaciantes, sabão líquido, multiusos, cândida, alvejantes, limpa pedra, entre outros;

- Empresa 18 - Produtos plásticos para setor pet: indústria de injeção plástica fabricante de produtos pet, como casas para animal, comedouros, frisbees, bebedouros, alimentadores, entre outros.

Cabe ressaltar que os resultados obtidos a partir da fase I já foram inclusive publicados no artigo "Diagnóstico da capacidade inovadora de pequenas e médias indústrias brasileiras" (BERTAZI; SALERNO, 2015).

Com o propósito de facilitar a compreensão do perfil das empresas, tabelas de resultados quantitativos são apresentadas a seguir. A amostra selecionada das 21 empresas possui a seguinte distribuição quanto ao porte: 
Tabela 2 - Caracterização da amostra quanto ao porte

\begin{tabular}{|l|c|}
\hline \multicolumn{1}{|c|}{ Funcionários } & $\begin{array}{c}\text { № de } \\
\text { indústrias }\end{array}$ \\
\hline Menos de 10 & 2 \\
\hline De 10 a 50 & 8 \\
\hline De 50 a 100 & 8 \\
\hline De 100 a 500 & 3 \\
\hline
\end{tabular}

\begin{tabular}{|l|c|}
\hline \multicolumn{1}{|c|}{ Faturamento anual } & $\begin{array}{c}\text { № de } \\
\text { indústrias }\end{array}$ \\
\hline Até $\mathrm{R} \$ 2,4$ milhões & 6 \\
\hline De $\mathrm{R} \$ 2,4$ a 15,6 milhões & 8 \\
\hline De $\mathrm{R} \$ 15,6$ a 90 milhões & 7 \\
\hline
\end{tabular}

Fonte: Elaboração própria.

Pelo fato de as empresas pertencerem a setores industriais distintos, a dinamicidade do ambiente externo também é variada:

Tabela 3 - Caracterização da amostra quanto ao porte

\begin{tabular}{|l|c|}
\multicolumn{1}{|c|}{ Ambiente externo } & $\begin{array}{c}\text { № de } \\
\text { indústrias }\end{array}$ \\
\hline $\begin{array}{l}\text { Marcado por mudanças rápidas e radicais por causa de evoluções } \\
\text { tecnológicas e mercadológicas: há lançamento constante de gerações de } \\
\text { produtos totalmente novas e mudanças na liderança do mercado são } \\
\text { frequentes }\end{array}$ & 5 \\
\hline $\begin{array}{l}\text { Mudanças rápidas, mas sem grandes saltos tecnológicos ou rupturas de } \\
\text { Mercado }\end{array}$ & 6 \\
\hline $\begin{array}{l}\text { Mudanças raramente ocorrem: concorrentes dificilmente lançam novos } \\
\text { produtos }\end{array}$ & 2 \\
\hline $\begin{array}{l}\text { Mudanças são lentas e incrementais: concorrentes lançam apenas pequenas } \\
\text { atualizações em seus produtos }\end{array}$ & 8 \\
\hline
\end{tabular}

Fonte: Elaboração própria.

Em relação aos preços praticados de seus produtos, a maioria aponta similaridade com os seus concorrentes nacionais:

Tabela 4 - Preço dos produtos em comparação à concorrência

\begin{tabular}{|l|c|}
\hline \multicolumn{1}{|c|}{ Preço dos produtos } & $\begin{array}{c}\text { № de } \\
\text { indústrias }\end{array}$ \\
\hline Mais barato do que concorrência nacional & 1 \\
\hline Mais caro do que concorrência internacional & 2 \\
\hline Mais caro do que concorrência nacional & 5 \\
\hline $\begin{array}{l}\text { Preços similares aos concorrentes } \\
\text { internacionais }\end{array}$ & 1 \\
\hline Preços similares aos concorrentes nacionais & 12 \\
\hline
\end{tabular}

Fonte: Elaboração própria. 
Quando questionadas acerca da estratégia de inovação, as empresas apontam o esforço em buscarem o pioneirismo em seus setores. (As empresas puderam assinalar mais de uma resposta para esta questão.)

Tabela 5 - Estratégia de inovação de empresas

\begin{tabular}{|l|c|}
\hline \multicolumn{1}{|c|}{ Estratégia de inovação } & $\begin{array}{c}\text { № de } \\
\text { indústrias }\end{array}$ \\
\hline $\begin{array}{l}\text { A empresa possui uma estratégia explícita de lançamento de produtos ou } \\
\text { serviços para os dois próximos anos }\end{array}$ & 5 \\
\hline $\begin{array}{l}\text { A empresa possui uma estratégia tecnológica visando manter o fluxo } \\
\text { contínuo de lançamento de produtos e/ou serviços da empresa nos próximos } \\
\text { dois anos }\end{array}$ & 8 \\
\hline $\begin{array}{l}\text { A empresa adota uma estratégia de inovação voltada para ser a pioneira no } \\
\text { setor }\end{array}$ & 10 \\
\hline $\begin{array}{l}\text { A empresa adota uma estratégia de inovação voltada para ser a seguidora } \\
\text { rápida }\end{array}$ & 4 \\
\hline Em geral, a empresa é uma das últimas a entrar no mercado & 1 \\
\hline
\end{tabular}

Fonte: Elaboração própria.

O modo pelo qual a inovação ocorre nas empresas é dividido entre processos formais e informais. (As empresas puderam assinalar mais de uma resposta para esta questão.)

Tabela 6 - Modo pelo qual a inovação ocorre

\begin{tabular}{|l|c|}
\hline \multicolumn{1}{|c|}{ Modelo pelo qual a inovação ocorre } & $\begin{array}{c}\text { № de } \\
\text { indústrias }\end{array}$ \\
\hline De maneira informal baseada na liderança da alta direção da empresa & 8 \\
\hline Estamos desenvolvendo o nosso primeiro produto & 2 \\
\hline $\begin{array}{l}\text { Por meio de um processo sistemático de lançamento de novos produtos e/ou } \\
\text { serviços }\end{array}$ & 11 \\
\hline $\begin{array}{l}\text { Somente em casos mais extremos como exigências dos clientes ou } \\
\text { lançamento de produtos e/ou serviços dos concorrentes }\end{array}$ & 5 \\
\hline
\end{tabular}

Fonte: Elaboração própria.

A maioria das empresas afirma ter pelo menos algum processo formal em pelo menos parte do desenvolvimento de produtos. Contudo, destaca-se o fato de nenhuma ter apontado a existência de processo formal para seleção de projetos. (As empresas puderam assinalar mais de uma resposta para esta questão.) 
Tabela 7 - Existência de processos formais por tipo

\begin{tabular}{|l|c|}
\hline \multicolumn{1}{|c|}{ Processo formal para } & $\begin{array}{c}\text { № de } \\
\text { indústrias }\end{array}$ \\
\hline Gerar novas ideias envolvendo o time de inovação & 4 \\
\hline $\begin{array}{l}\text { Gerar e/ou coletar ideias entre departamentos ou pessoas que estão fora da } \\
\text { área formal de inovação ou/e desenvolvimento de produtos }\end{array}$ & 4 \\
\hline Gerar ou coletar ideias a partir de clientes, universidades e/ou fornecedores & 6 \\
\hline Pré-desenvolver ou amadurecer ideias antes de transformá-las em projetos & 5 \\
\hline Selecionar projetos de inovação & 0 \\
\hline Desenvolver projetos de inovação & 5 \\
\hline Nenhum & 3 \\
\hline
\end{tabular}

Fonte: Elaboração própria.

Quanto ao uso de algum indicador ou sistema de indicadores para medição do desempenho de inovação, dezesseis empresas afirmam não utilizar nenhum, enquanto cinco utilizam pelo menos um. Durante a fase II da pesquisa, buscou-se compreender primeiramente quais são estes indicadores utilizados.

Todas as empresas respondentes apontam ter pelo menos um desafio para inovar. Os obstáculos são distintos para cada uma das empresas, conforme pode ser visto a seguir. (As empresas puderam assinalar mais de uma resposta para esta questão.)

Tabela 8 - Maiores desafios para inovação

\begin{tabular}{|l|c|}
\hline \multicolumn{1}{|c|}{ Desafios para inovação } & $\begin{array}{c}\text { № de } \\
\text { indústrias }\end{array}$ \\
\hline $\begin{array}{l}\text { Melhorar o projeto do produto, compreendendo com maior profundidade as } \\
\text { necessidades dos clientes e superando o desempenho do produto }\end{array}$ & 9 \\
\hline Melhorar o design ou/e o posicionamento do produto no mercado & 8 \\
\hline Conseguir captar melhores ideias dentro da empresa & 5 \\
\hline $\begin{array}{l}\text { Conseguir captar melhores ideias em parceiros-chave da empresa: } \\
\text { fornecedores, clientes, universidades, entre outros }\end{array}$ & 10 \\
\hline $\begin{array}{l}\text { Selecionar melhor os projetos de inovação, com critérios mais claros e } \\
\text { balanceados }\end{array}$ & 6 \\
\hline Conseguir desenvolver sistematicamente produtos & 8 \\
\hline $\begin{array}{l}\text { Passar a inovar em outras dimensões: serviços, modelos de negócios e } \\
\text { tecnologia }\end{array}$ & 12 \\
\hline $\begin{array}{l}\text { Conseguir melhorar o lançamento e a difusão das inovações dentro e/ou fora } \\
\text { da empresa }\end{array}$ & 8 \\
\hline
\end{tabular}

Fonte: Elaboração própria. 
Adicionalmente ao questionário remoto aplicado, foram obtidos aspectos adicionais de natureza qualitativa - durante as entrevistas e observações presenciais do pesquisador durante os atendimentos do projeto NAGI em seis empresas, conforme tratado no início deste capítulo. A síntese destas observações é apresentada a seguir:

- Discrepância do que as empresas respondem remotamente no pré-diagnóstico do que realmente é observado. Os principais motivos estão na falta de conceitos relacionados à inovação e à sua gestão, na valorização de seus negócios sem o devido senso crítico e no conhecimento parcial do mercado em que estão inseridos;

- Falta de mentalidade e cultura inovadora em cerca de metade do grupo estudado. A capacitação para gestão da inovação é uma lacuna percebida nas interações;

- Visão imediatista e de curto prazo. Constatação corrobora com o estudo de Vos, Keizer e Halman (1998) que aponta que em empresas pequenas, os administradores têm um planejamento de curto prazo, ficando presos num círculo vicioso onde a resolução de problemas diários impede a definição de estratégias de longo prazo e de inovação;

- A maioria das empresas estudadas possuem problemas de organização e de boa utilização de ferramentas de gestão de projetos. Muitas vezes, as ferramentas e os processos utilizados são muito frágeis, sem modelo formalizado ou são "burlados" pela própria liderança da organização, o que enfraquece a gestão de projetos;

- Do ponto de vista do processo de inovação, evidenciou-se que a maioria das indústrias possui como principal gargalo a etapa de desenvolvimento. A geração de ideias não é o mais crítico, seja por ideias geradas internamente ou pela demanda do mercado. O lançamento também não é complexo, dado que as inovações são incrementais, e os canais já estão estabelecidos e os clientes desenvolvidos;

- Principais problemas observados redundam nas questões de prazo de desenvolvimento muito longos, o que aumenta o custo de desenvolvimento de 
produtos e o time to market, que pode gerar perda do mercado para concorrência (em mercados mais dinâmicos) ou simplesmente postergação das receitas - que se torna crítico em empresas em que o capital de giro é representativo no fluxo de caixa da empresa.

Cabe ressaltar que os aprendizados gerados durante a fase I são de valia para o estudo, porém são preliminares, sendo aprofundados nas fases II e III. Os resultados gerados orientaram a seleção de casos para as fases posteriores, visando a discussão das questões centrais desta pesquisa.

$\mathrm{Na}$ próxima seção será abordada a fase II desta pesquisa, que aprofunda a compreensão do processo de inovação e de sua gestão em dois casos selecionados. Os aprendizados obtidos em relação ao uso de sistemas de gestão e indicadores de inovação nestas empresas são fundamentais para o desenvolvimento da ferramenta - fase III - e por provavelmente representarem parcela relevante do universo de PMEs tradicionais brasileiras. 


\section{FASE II - PROCESSO DE INOVAÇÃO E SUA GESTÃO}

A partir dos aprendizados obtidos pelo projeto NAGI, tangibilizado pela fase I desta pesquisa, a fase II buscou aprofundar a compreensão do processo de inovação e de sua gestão em empresas selecionadas, além de identificar a utilização de sistemas de gestão e indicadores utilizados por pequenas e médias indústrias tradicionais.

Como objetos de pesquisa, foram selecionados dois casos a partir da lista de 21 empresas atendidas pelo projeto NAGI no perfil de interesse: a empresa 2, do setor de autopeças, e a empresa 11, do setor de iluminação. A escolha foi realizada por ambas apresentarem processo contínuo de desenvolvimento de novos produtos, por terem porte não muito pequeno em relação a funcionários e faturamento e pela facilidade de acesso a colaboradores e informações - características identificadas durante os atendimentos do projeto NAGI conduzidos pelo pesquisador.

Foram realizadas entrevistas semiestruturadas e observações presenciais nas duas empresas selecionadas, com foco na identificação de processos de inovação, sua gestão e quais indicadores seriam utilizados. O procedimento adotado permitiu a condução do pesquisador orientado às questões centrais, sem limitar a possibilidade do entrevistado em discutir assuntos considerados importantes para a pesquisa. Duas reuniões com cada uma das empresas ocorreram em janeiro de 2017, com duração de duas a três horas cada uma, junto aos gerentes responsáveis pelo desenvolvimento de novos produtos nas duas PMEs. Deve-se ressaltar que o pesquisador já possuía conhecimento prévio das duas empresas decorrente dos atendimentos e acompanhamentos do projeto NAGI realizados - descritos na fase I -, além de documentos que foram coletados e gerados no mesmo período.

A seguir é apresentado quadro com o roteiro inicial seguido pelo pesquisador durante as entrevistas semiestruturadas, organizado por dimensões e principais tópicos discutidos. As dimensões "caracterização da empresa”, "estrutura organizacional” e "gestão da inovação" foram discutidas mais brevemente pelo conhecimento prévio do pesquisador. Após explanação, tópico a tópico, das principais mudanças pelos responsáveis pela função desenvolvimento de novos produtos nas empresas, 0 pesquisador sintetizava suas compreensões e validava com os interlocutores. As últimas duas dimensões foram conduzidas acompanhando o processo de inovação 
proposto por Hansen e Birkinshaw (2007), abordando como era o processo e quais indicadores eram eventualmente utilizados. Em relação aos sistemas e indicadores de inovação, quando a resposta era negativa, faziam-se provocações para obter eventuais processos de mensuração ou indicadores implícitos. Com este objetivo, também era solicitado ao gestor para que apresentasse planilhas, relatórios e documentos utilizados para gestão dos processos de desenvolvimento de novos produtos.

Quadro 9 - Roteiro de pesquisa da fase II

\begin{tabular}{|l|l|}
\hline Dimensões & Principais tópicos \\
\hline Caracterização da empresa & - Histórico da empresa \\
& - Produtos oferecidos \\
& - Diferencial para o mercado \\
& - Modelo de negócio \\
\hline Estrutura organizacional & - Como a organização está estruturada? \\
& - Qual é a área responsável por coletar ideias e \\
& - desenvolver inovações? \\
\hline Gestão da inovação & - O que é inovação no contexto da empresa? \\
& - Estratégia de inovação \\
& - Tipos de produtos desenvolvidos \\
\hline Processo de inovação & - Como as ideias são geradas? \\
& - Como são selecionadas e priorizadas? \\
& - Como se dá o desenvolvimento? \\
& - Como é a implantação das inovações? \\
\hline Sistema de medição de desempenho e & - Como o processo se relaciona com pessoas e \\
indicadores de inovação & organização? \\
\hline
\end{tabular}

Fonte: Elaboração própria.

Os dois casos estudados são apresentados e analisados a seguir. 


\subsection{CASO 1 - EMPRESA 11 (ILUMINAÇÃO)}

\subsubsection{Caracterização}

Indústria do ramo de iluminação que trabalha com design embarcado em seus produtos, integrando o conceito de iluminação e arquitetura. Oferece soluções completas, que podem ir desde projeto até a instalação final. Seus produtos são considerados no mercado como de qualidade superior e luxo para residências, escritórios e espaços comerciais.

A empresa é uma das pioneiras em tendências neste ramo no Brasil, baseando-se em empresas de referências internacionais e também desenvolvendo seus próprios produtos. Possui diversos prêmios nacionais e internacionais de design e relacionados a força de marca.

Além de atender ao consumidor final, possui área de relacionamento com pessoas jurídicas, atuando com projetos de hotelaria, restaurantes e lojas. Há ainda o atendimento de decoradores e designers de interiores, influenciadores importantes neste mercado, e também que consomem seus produtos.

A empresa conta hoje com cerca de 100 colaboradores, estando metade localizados fora da sua sede, em lojas próprias e funções comerciais e de relacionamento.

\section{$\underline{5.1 .2 \text { Histórico }}$}

Fundada em 1985, iniciou com a proposta de integrar iluminação à arquitetura, em momento histórico em que o conceito de iluminação se resumia a lustres e abajures. Adicionalmente, tinha como modelo de negócio a possibilidade de oferecer soluções completas, que envolviam desde o projeto à instalação final, algo que posteriormente mostrou ser um grande diferencial da empresa. A visão pioneira e a qualidade dos produtos foram responsáveis por alçar a empresa como uma das atuais líderes do mercado de iluminação brasileiro.

Ao longo dos anos, a empresa agregou o design para produzir sensações em seus clientes, na mesma lógica da arte contemporânea, ao invés de apenas decorar ambientes. Para isso, desenvolveu um modelo de curadoria de coleções, com 
colaboradores próprios e outros contratados por projetos ou coleções. Nos últimos anos, a empresa também assumiu como compromisso o incentivo aos designers nacionais, promovendo criações genuinamente brasileiras. Contudo, a marca segue com parcerias com empresas internacionais tradicionais, as mesmas que suportaram o crescimento no passado.

Além de indústria, a empresa possui lojas físicas: próprias e franquias. No varejo, os ambientes foram construídos de modo a valorizar os produtos e procuram estimular experiências sensoriais proporcionados por eles. Sempre há um designer responsável que assina a fachada e o interior da sede e das lojas da empresa.

\section{$\underline{\text { 5.1.3 Estrutura organizacional }}$}

A empresa está estruturada conforme organograma a seguir:

Figura 10 - Organograma da empresa: caso 1

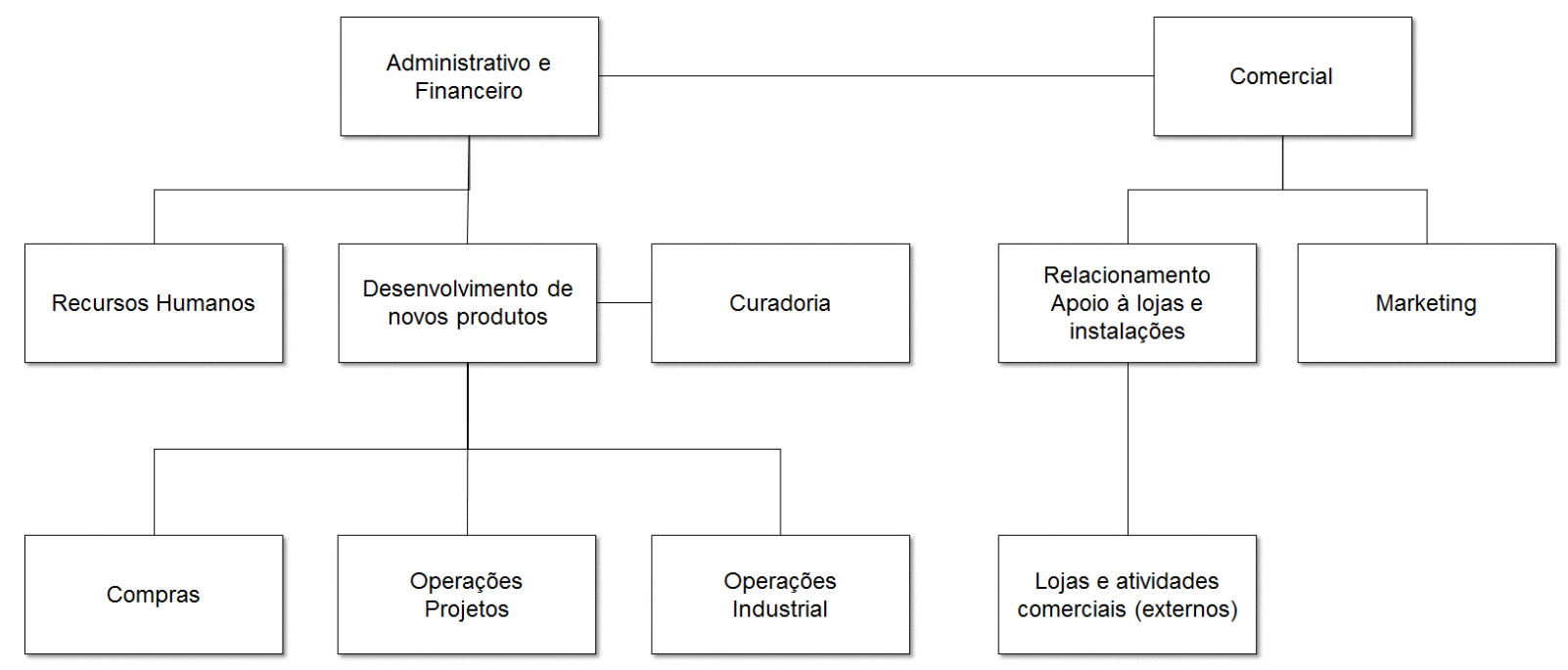

Fonte: Elaboração própria.

Conforme pode ser observado, há duas grandes diretorias: a comercial e a administrativa financeira, que abarca o desenvolvimento de novos produtos e as operações.

A gerência de desenvolvimento de novos produtos é central na estrutura, pois dela se origina todo o portfólio da empresa, além de se relacionar com as áreas de compras e de operações, responsável por produzir os produtos concebidos por ela. As duas 
áreas de operações, uma voltada a projetos de instalações o outra voltada a produtos de linha, participam do processo sendo consultadas quanto a aspectos técnicos para o desenvolvimento.

A área de desenvolvimento possui quatro pessoas exclusivas para esta função, sendo responsável pelas inovações de produto na empresa. A curadoria, com dois colaboradores em tempo parcial e alguns parceiros externos, complementa a função inovação da empresa, trazendo tendências do setor de iluminação no mundo e elaborando desenhos conceituais para o desenvolvimento.

\section{$\underline{5.1 .4 \text { Inovação na empresa }}$}

Assim como na indústria da moda, a empresa trabalha com o conceito de coleções, sendo desenvolvidos cerca de quarenta produtos de linha por ano. O ciclo de vida é de aproximadamente dois anos, quando então se decide se o produto será descontinuado ou "repaginado", o que tecnicamente se traduz em um novo processo de desenvolvimento de produto.

Portanto, na prática, a gestão da inovação desta empresa se traduz na gestão dos projetos de desenvolvimento dos novos produtos.

A ideação normalmente se inicia pela curadoria, área composta por dois colaboradores em regime de tempo parcial e por um rol de colaboradores externos, residentes no Brasil e no exterior. O papel destes colaboradores é desenvolver o conceito e o design das peças, estando atentos a algumas especificidades técnicas como uso de materiais, estrutura elétrica, facilidade de fabricação, entre outros -, apontadas pela equipe de desenvolvimento. Estes profissionais sempre buscam inspirações em eventos de renome internacionais e revistas do setor, tendo produção autoral. Cabe ressaltar que há um pequeno ecossistema envolvido nas produções, pois os designers do segmento de iluminação conversam entre si.

Após a finalização dos desenhos técnicos, conclui-se a etapa de ideação e inicia-se o desenvolvimento. A ilustração a seguir descreve este processo: 
Figura 11 - Processo de desenvolvimento: caso 1

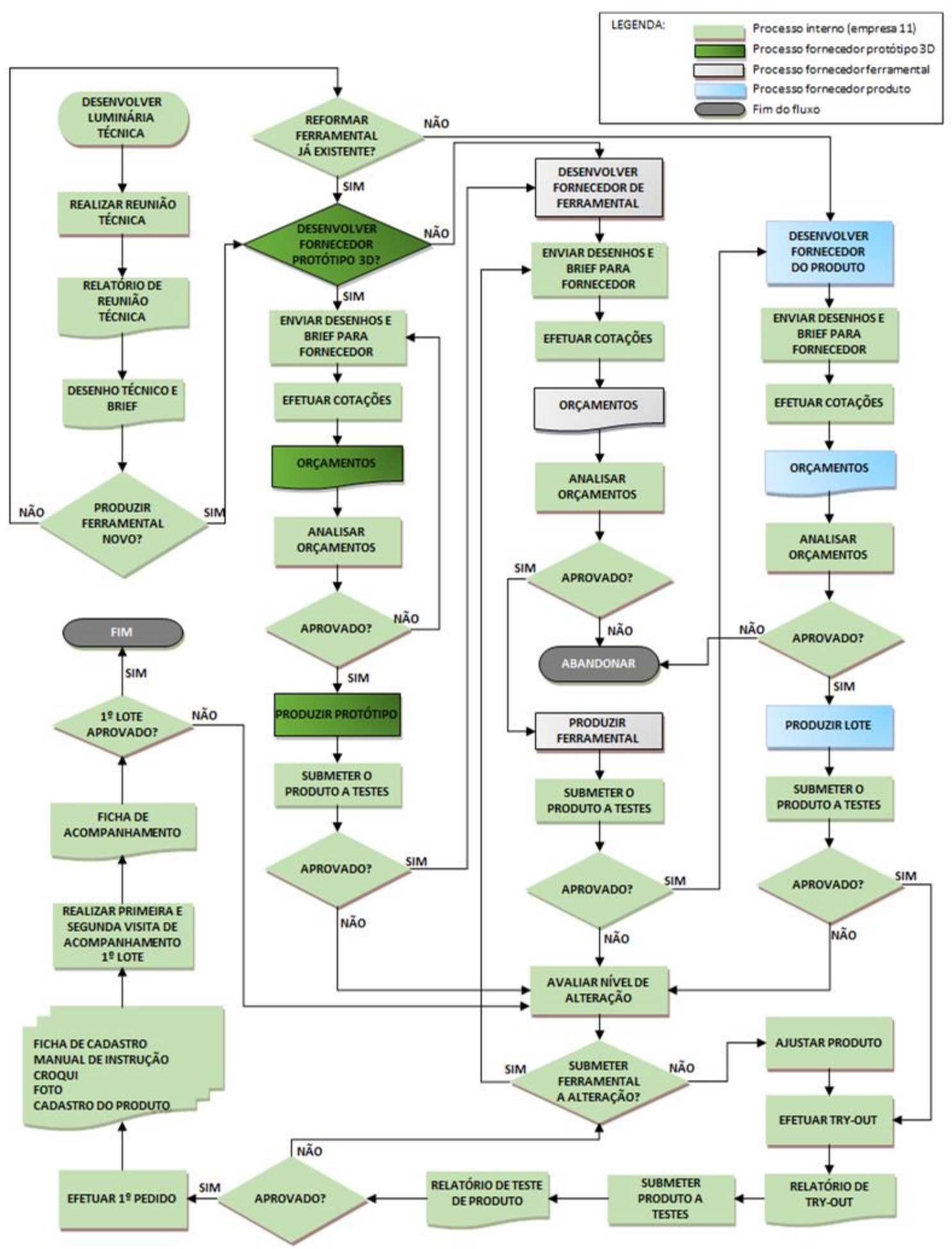

Fonte: Elaboração própria.

Os processos de desenvolvimento são conduzidos na lógica de gestão de projetos típicos, com duração usual de 3 a 6 meses por produto, dependendo da complexidade e do número de idas e vindas no processo. Os maiores atrasos ocorrem na interação 
com fornecedores, que são responsáveis pela orçamentação e a realização de protótipos. Em média, são desenvolvidos cerca de quarenta produtos por ano.

O principal desafio no desenvolvimento é a realização de etapas importantes por parceiros que realizam protótipos, orçamentos e lotes experimentais. Estas atividades podem atrasar demasiadamente os projetos, impactando o lançamento e a posterior estratégia comercial. Nota-se que, por vezes, as causas do atraso ora têm origem no fornecedor, ora na própria empresa. Como exemplo, pode-se citar a sobredemanda dos fornecedores em alguns períodos, uma vez que atendem a diversas indústrias, e eventuais informações incompletas de projeto encaminhadas pela empresa.

Após a aprovação do lote teste, o produto é encaminhado para a área responsável de operações para ser fabricado em escala. Assim, inicia-se a fase de lançamento, que é realizada mediante exposição dos produtos nos catálogos e nas lojas da marca e ações de marketing específicas junto ao público alvo, como eventos, meios digitais, revistas especializadas e parceiros que comercializam os produtos. A equipe comercial também é treinada para a apresentação dos produtos aos clientes e formadores de opinião, como arquitetos e decoradores.

\section{$\underline{\text { 5.1.5 Sistema de medição de desempenho e indicadores de inovação }}$}

A empresa não utiliza um sistema de medição de desempenho formal para gestão da inovação. Contudo, podem ser observados alguns indicadores de inovação, ainda que não explícitos e sistematizados pela empresa:

- Ideação: os indicadores relacionados a ideação são simples. Basicamente, monitoram o número de projetos trazidos pela curadoria interna e externa em determinado período e a quantidade de projetos aprovados e rejeitados. Não há critério estabelecido para seleção de projetos ou quantidade de projetos a serem aprovados para desenvolvimento, o que teria relação com orçamento ou disponibilidade de equipe para a etapa posterior. A avaliação é realizada caso a caso e, dependendo do período, é mais ou menos criteriosa dependendo do número de ideias de novos produtos gerados. 
- Desenvolvimento: os principais indicadores são monitorados nesta etapa, considerada a mais crítica para a empresa. Acompanham-se o número de projetos em desenvolvimento, o número de protótipos produzidos e o tempo de desenvolvimento por projeto. O número de protótipos produzidos tem importância já que podem ser realizados mais de um por projeto, o que incorre em custos extras, seja por erros de produção ou por solicitação de mudanças. O tempo de desenvolvimento por projeto, em dias, ainda pode ser observado por atividades, como tempo até a realização do orçamento, tempo para realização do primeiro protótipo, e assim por diante.

- Lançamento: basicamente nesta etapa são mensurados apenas os resultados finalísticos, como o número de produtos lançados no ano, a quantidade vendida referente a estes novos produtos e também o faturamento correspondente.

Cabe ressaltar que os indicadores foram identificados pelo pesquisador durante a entrevista, pois a empresa não os utiliza formalmente como sendo parte de um processo estruturado. Não há períodos pré-estabelecidos para mensuração ou análise, sendo realizados por solicitação da diretoria ou quando se identifica algum problema recorrente em projetos em um curto espaço temporal. Ainda, destaca-se que os indicadores descritos, quando utilizados, não nortearam ações para melhoria dos processos de desenvolvimento de produtos no passado.

\subsection{CASO 2 - EMPRESA 2 (AUTOPEÇAS)}

\subsubsection{Caracterização}

Indústria do setor metal mecânico com aproximadamente 230 funcionários especializada em metalurgia do pó. Produz pós metálicos não ferrosos e peças sinterizadas, atendendo majoritariamente o setor automotivo por meio de fornecimento de autopeças a sistemistas. Atende também à indústria de linha branca, ou eletrodomésticos.

Basicamente, a empresa fabrica produtos substitutos de peças tradicionais dos setores automotivo e de linha branca, produzidas usualmente por processos de fundição e usinagem. Como principais produtos comercializados, pode-se citar: 
- Pós metálicos: a partir de atomização à água;

- Aplicações dos pós metálicos para produtos: peças sinterizadas, ferramentas diamantadas e rebolos, componentes de friç̧ão, tintas e pigmentos, brasagem (tratamento térmico) e pastas para soldas;

- Componentes de precisão para aplicações automotivas: suspensão, motores, transmissão, bombas de óleo e água, diversos sistemas elétricos, entre outros;

- Aplicações em eletrodomésticos: compressores herméticos, mancais, engrenagens para transmissão em lavadoras de roupa, entre outros;

- Aplicações em ferramentas elétricas.

A empresa tem como principais clientes: Grupo SEB, Whirlpool, Fiat, Philips, Bosch, Tecumseh, Magneti Marelli, Tenneco, TRW, Valeo e Yamaha.

\section{$\underline{5.2 .2 \text { Histórico }}$}

A empresa foi fundada em 1967, sendo dedicada exclusivamente à metalurgia do pó, produzindo pós metálicos não ferrosos e peças sinterizadas. Pertence a um grupo fundado em 1959, ligado à siderurgia, metalurgia e petroquímica.

Dadas as necessidades da época, a empresa desenvolveu tecnologia para a fabricação de pós metálicos e é hoje a principal fabricante sul americana de pós atomizados não ferrosos, destinados à sua própria produção de peças e também ao mercado em geral em diversas aplicações.

Para as peças sinterizadas foram desenvolvidos equipamentos de produção utilizando recursos da empresa coligada do grupo que atua na área de bens de capital. Buscando sempre domínio da tecnologia em metalurgia do pó, a empresa possui também ferramentaria para preparação de todos os recursos necessários para a produção de componentes sinterizados.

Desde o início de suas atividades, a empresa vem estabelecendo parcerias pontuais no desenvolvimento de novos produtos, acumulando conhecimento em sua área de atuação. Sendo uma das responsáveis pela introdução e divulgação da metalurgia do 
pó no mercado brasileiro, a empresa é atualmente reconhecida no exterior e exporta produtos para empresas da América do Norte e do Sul, Europa, China e Indonésia.

\section{$\underline{5.2 .3 \text { Estrutura organizacional }}$}

A empresa está estruturada conforme organograma a seguir:

Figura 12 - Organograma da empresa: caso 2

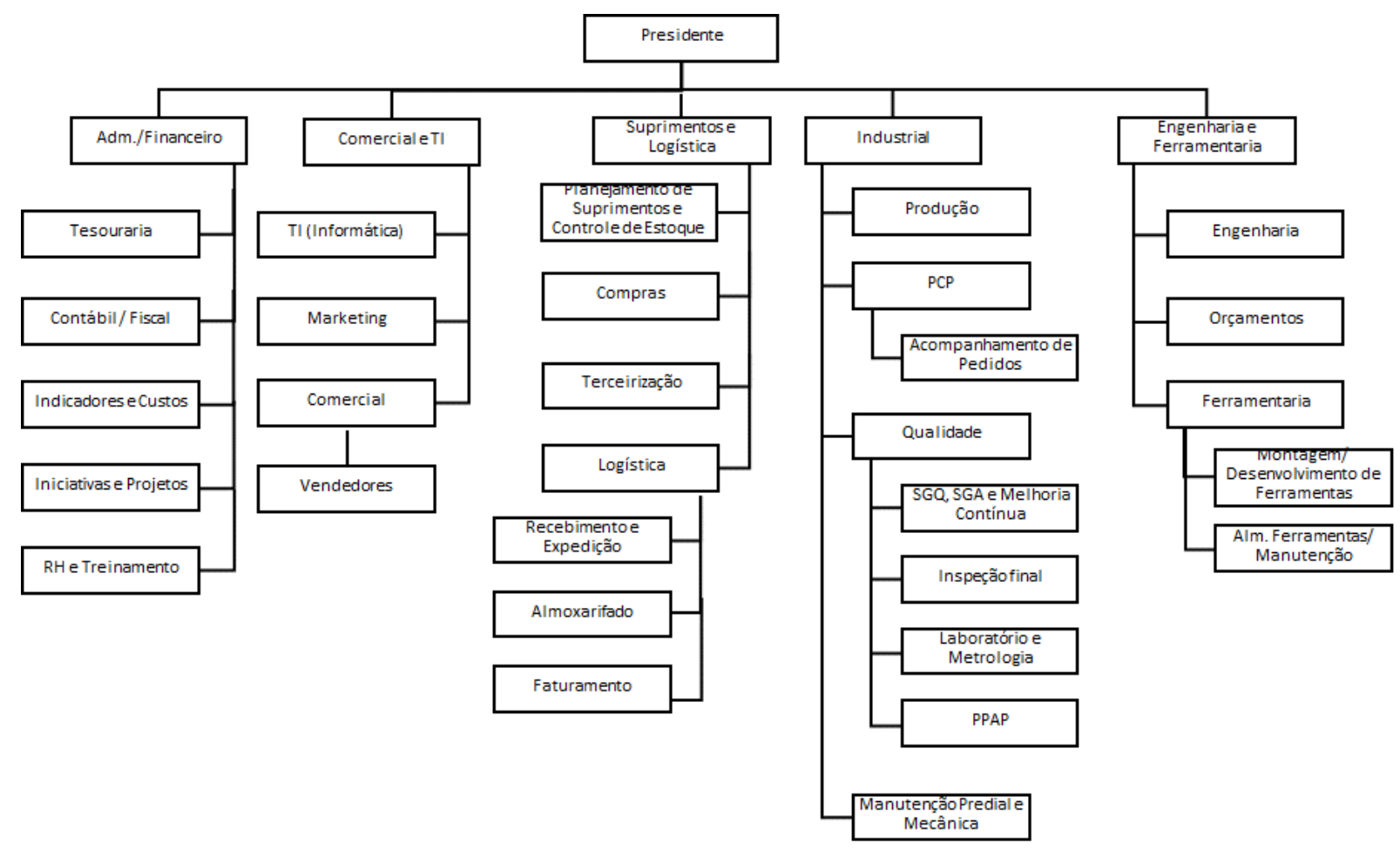

Fonte: Elaboração própria.

O desenvolvimento de novos produtos é disparado internamente de duas formas: (i) demanda da área comercial por solicitação de algum cliente, mais frequente, ou (ii) projeto interno da área de engenharia. Em ambos os casos, a diretoria de engenharia e ferramentaria é central na função desenvolvimento de novos produtos.

Usualmente, após solicitação de pedido, a área comercial encaminha a demanda para a área de orçamentos, que será responsável por coletar as informações necessárias para construção da planilha de preços. 
A área de orçamentos funciona como integradora, requisitando informações das áreas de engenharia, ferramentaria, comercial, compras, produção e eventualmente até da presidência, quando o cliente ou o pedido é considerado estratégico.

A área de engenharia realiza estimativas prévias baseada em desenhos para a área de orçamentação, e eventualmente há o envolvimento das áreas de ferramentaria e produção neste processo, quando o pedido é mais complexo. A área de compras é solicitada para verificar atualização de preços e disponibilidade de eventuais matérias primas e sobressalentes. Comercial é envolvido na etapa final, quando o cliente é estratégico ou eventualmente se há discordâncias quanto à precificação.

Após o aceite do orçamento por parte do cliente, a função desenvolvimento de novos produtos fica a cargo da área de engenharia, que trabalha em conjunto com a área de ferramentaria e, eventualmente, produção - na figura do diretor industrial.

\section{$\underline{5.2 .4 \text { Inovação na empresa }}$}

Conforme já explicitado, a inovação de produtos ocorre usualmente a partir da abordagem comercial da empresa, em que reativamente a empresa procura desenvolver autopeças de preço mais baixo às utilizadas pelo mercado normalmente fabricadas por processo de usinagem - de modo que é conduzido um projeto interno para se analisar a viabilidade. Quando a empresa inicia este processo proativamente, a inovação começa na área de engenharia, que visa desenvolver um produto substituto ao mercado. Esta seria, portanto, a etapa que poderia ser comparada à ideação do processo tradicional descrito pela literatura.

Em outros termos, ou a empresa oferece a possibilidade de substituir uma solução existente ao mercado por metalurgia do pó - de modo que a peça final seja mais barata e mantenha suas características técnicas essenciais - ou quando um elo à frente da cadeia automotiva - um sistemista, por exemplo - faz uma solicitação sobre a possibilidade de redução de custos via metalurgia do pó.

A inovação nesses casos se materializa através de projeto de desenvolvimento de novo produto que, caso se demonstre viável e aceito pelo cliente, passa a ser produzido em escala mediante contrato de fornecimento assinado com o comprador, 
normalmente com duração de dois anos. A ilustração a seguir descreve o processo completo de desenvolvimento de novos produtos na empresa:

Figura 13 - Processo de desenvolvimento: caso 2

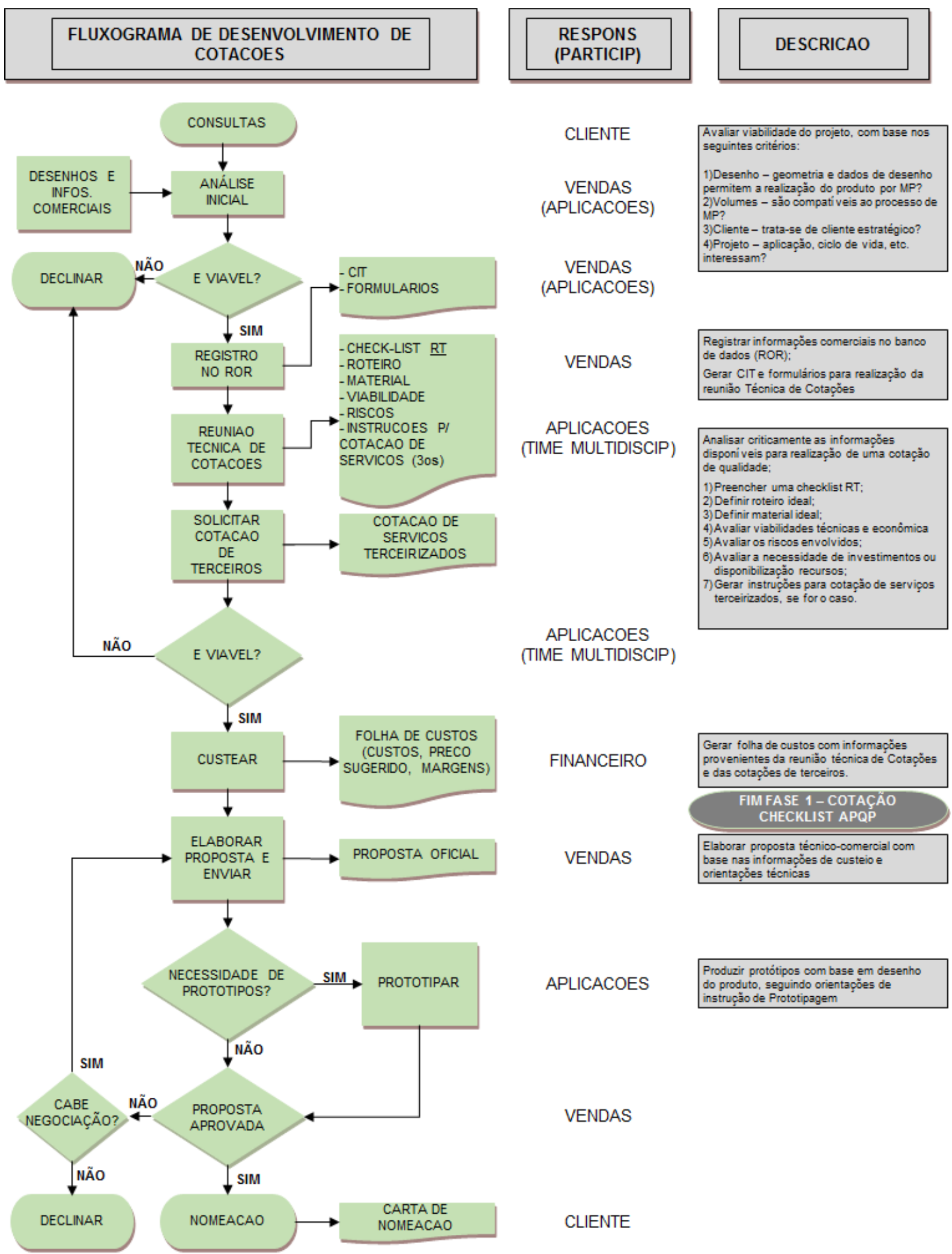




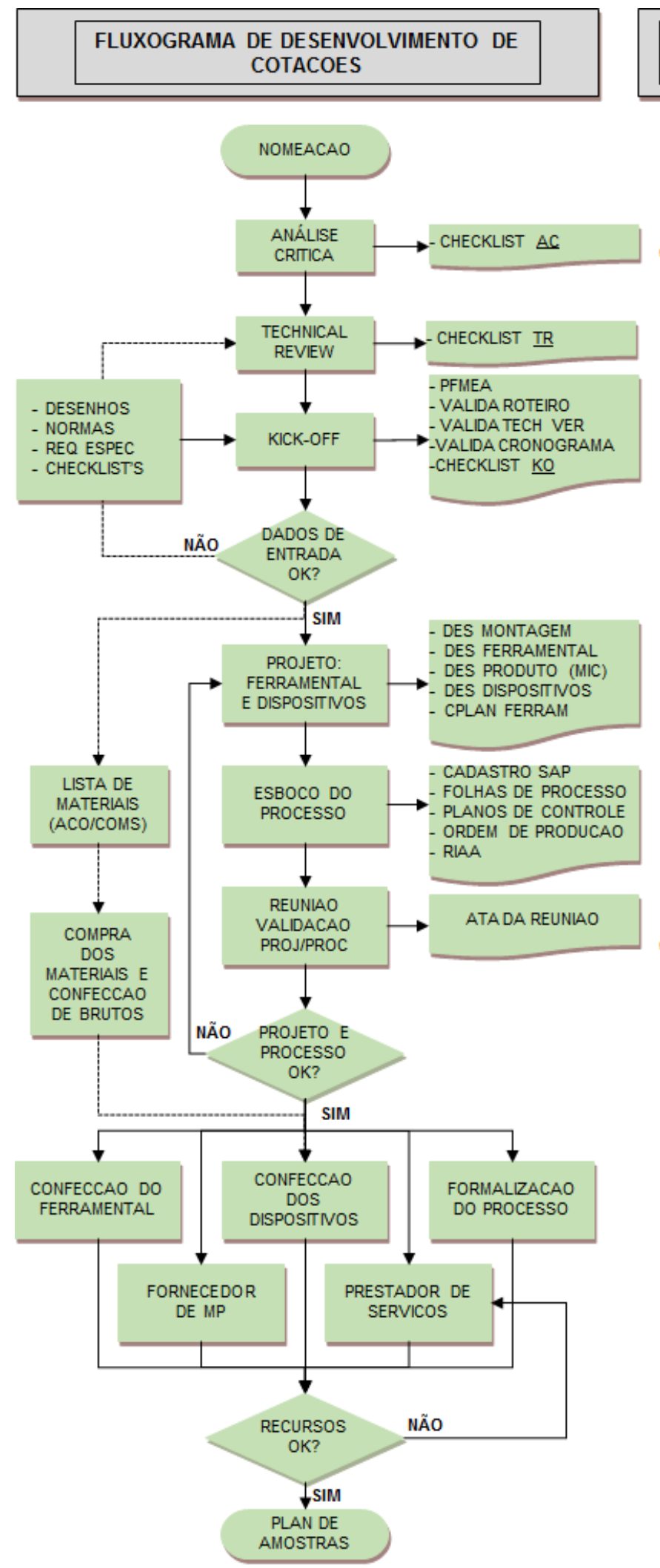

APLICACOES

(TIME MULTIDISCIP)

APLICACOES

(VENDAS)

ENGENHARIA DE

PROJETOS

(FERRAMENTARIA)

ENGENHARIA DE

PROCESSOS

(QUALIDADE)

APLICACOES

(TIME MULTIDISCIP) 

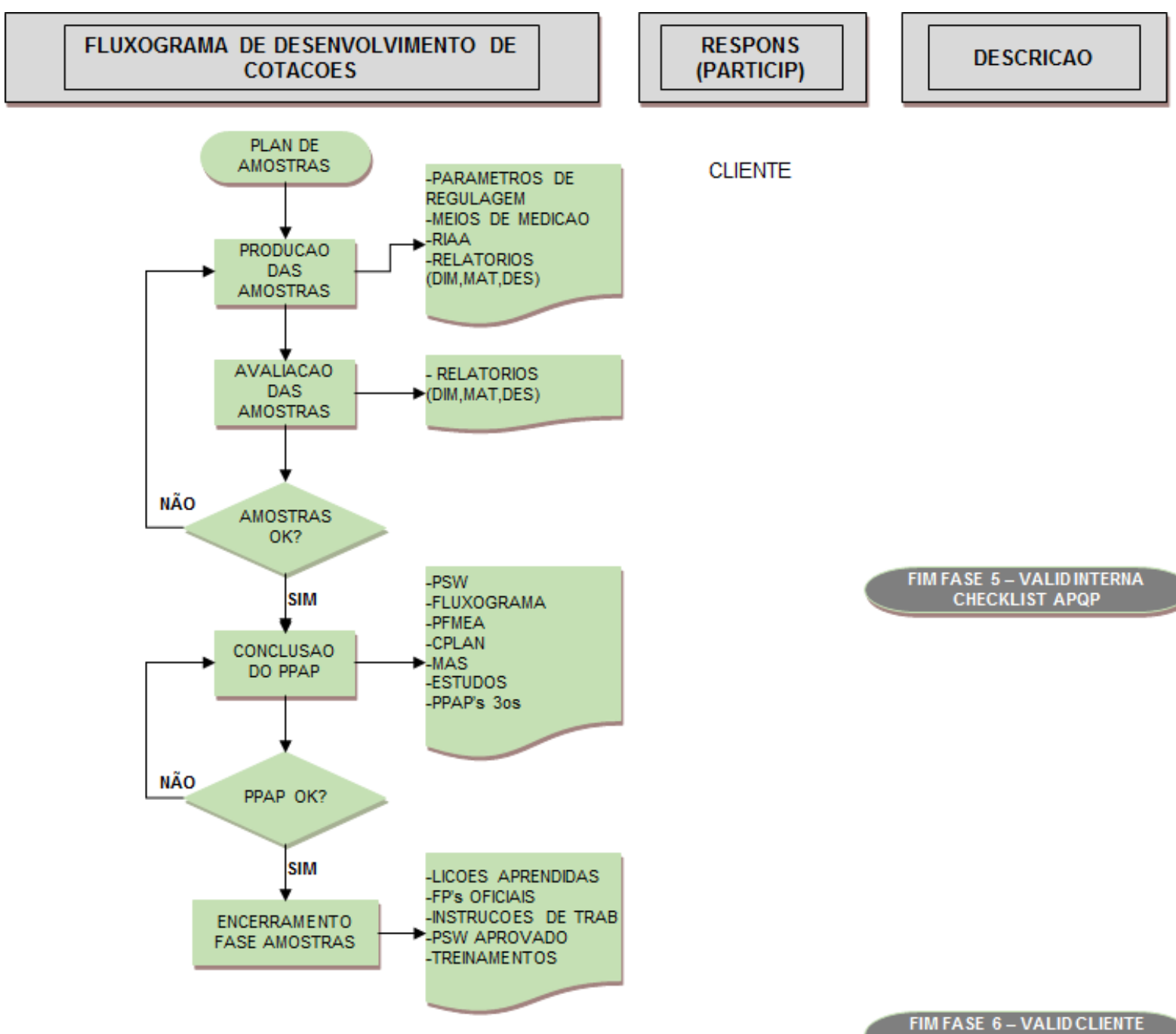

CLIENTE

Fonte: Elaboração própria.

Após aprovação do orçamento enviado ao cliente, inicia-se o desenvolvimento de produtos propriamente dito. Como o modelo da empresa em análise é iniciado mediante um contrato assinado, não há a etapa de seleção e priorização de projetos, pois eles já estão com demanda garantida. O desafio de inovação da empresa se resume, portanto, no desenvolvimento.

Conforme apresentado pela figura, a primeira etapa consiste em uma revisão técnica, em que o comercial valida com o cliente as aplicações do produto e as especificidades necessárias, como dimensões críticas, grau de esforço, entre outros.

Na sequência, há uma reunião de início de projeto formal, em que são envolvidas as áreas de engenharia, ferramentaria e processos/qualidade e as tarefas são paralelizadas. São desenvolvidos os desenhos e projetos dos produtos, das 
ferramentas e o processo produtivo, descrevendo-se as futuras etapas para fabricação. Após validação conjunta, deste time, há a confecção do ferramental, aquisição de matérias primas, formalização de contratos com terceiros se necessário e formalização de processos em documentação apropriada.

Em seguida, inicia-se a etapa de produção de amostras, correspondente à prototipagem na abordagem teórica. As amostras são produzidas, medidas e avaliadas até serem aprovadas pelo comitê responsável pelo desenvolvimento de produtos, formado pela engenharia, ferramentaria, qualidade e diretoria industrial.

Após encerramento desta etapa, um primeiro lote é enviado ao cliente para aprovação. Quando aprovado, a responsabilidade é entregue à diretoria industrial, que iniciará o processo produtivo em escala contratada e prevista em contrato.

A etapa de difusão ou de lançamento, descrita na literatura, não se aplica neste caso, uma vez que o desenvolvimento já realizado com demanda garantida e cliente específico, ou seja, o mercado já é pré existente e definido para o produto que está sendo desenvolvido.

Em média são sessenta novos projetos por ano, que podem se somar ao portfólio de desenvolvimento do ano anterior - ainda não finalizados. Como se pode notar, os processos de desenvolvimento são conduzidos na lógica de gestão de projetos típicos, com duração usual de três meses a até mais de um ano por produto, dependendo da complexidade e do número de idas e vindas no processo. Normalmente, os clientes têm solicitado prazo de três a quatro meses para início da operação em escala.

Os maiores atrasos ocorrem na interação com clientes e devido a problemas internos entre as áreas, quando etapas do processo são suprimidas ou informações relevantes não são coletadas ou apontadas durante as atividades da equipe.

O principal desafio da empresa está na redução do tempo de desenvolvimento, uma vez que não conseguem responder a todas oportunidades que aparecem em tempo hábil, perdendo oportunidades de negócios. A eficiência deste processo, com menor quantidade de idas e vindas entre as atividades, permitiria inclusive que a empresa 
fosse mais proativa em desenvolvimentos, podendo propor ao mercado novas aplicações de sua tecnologia.

\section{$\underline{\text { 5.1.5 Sistema de medição de desempenho e indicadores de inovação }}$}

Assim como no primeiro caso, a empresa não utiliza um sistema de medição de desempenho formal para gestão da inovação. Contudo, podem ser observados alguns indicadores de inovação, ainda que não explícitos e sistematizados:

- Ideação: com a maioria das demandas partem dos clientes, os indicadores desta etapa são simplesmente o número de solicitações dos clientes para a área comercial, o número de pedidos rejeitados pelo comercial, o número de aprovações de orçamentos (projetos a serem desenvolvidos) e as ideias trazidas pela área de engenharia e aprovadas para desenvolvimento. A avaliação dos pedidos por parte da área comercial e de orçamentos leva em conta apenas a questão dos custos e da escala de produção necessária para um pedido isoladamente; não há critérios de seleção para o desenvolvimento com uma visão integrada de portfólio. Curiosamente, também não há controle dos faturamentos potenciais nesta fase, que poderia ser um indicador útil para a gestão.

- Desenvolvimento: conforme já explicitado, a maior preocupação da empresa reside nesta etapa. São registrados e, eventualmente monitorados, os números de projetos em desenvolvimento em cada uma das fases do processo: análise crítica, revisão técnica, projeto do ferramental, projeto do processo, produção de amostras e assim por diante. O tempo de desenvolvimento é registrado apenas quanto ao processo todo, não tendo a empresa uma visão consolidada da duração dos projetos por fase, o que dificulta a gestão de portfólio. Também não existe uma visão em tempo real do potencial financeiro ou estratégico dos projetos, dificultando as decisões de priorização na existência de limitação de equipe ou recursos. As idas e vindas no processo de desenvolvimento de produtos, embora comuns e frequentes no cotidiano da empresa, não são devidamente computadas para análise posterior. 
- Lançamento: como o desenvolvimento de produtos é realizado para cliente específico e demanda garantida, o conceito não se aplica muito bem a este caso. Basicamente, os indicadores que são monitorados referem-se ao número de projetos que foram desenvolvidos dentro do prazo acordado com o cliente e o número de amostras aceitas perante o total. Adicionalmente, a empresa mensura os resultados finalísticos, como o número de produtos lançados no ano e o faturamento correspondente a estes novos produtos.

Mais uma vez deve-se ressaltar que os indicadores foram identificados pelo pesquisador durante a entrevista, já que a empresa não os utiliza formalmente como sendo parte de um processo estruturado. Assim como no caso anterior, não há períodos pré-estabelecidos para mensuração ou análise, sendo estes realizados apenas quando solicitados pela presidência.

\subsection{APRENDIZADOS DA FASE II}

Nos dois casos analisados, tem-se a fase de conversão como a de maior desafio para a inovação de produtos, tendo como parâmetro o modelo de processo de inovação proposto por Hansen e Birkinshaw (2007). Notam-se problemas típicos de gestão de projetos, que acarretam em idas e vindas no processo, gerando atrasos no tempo total de desenvolvimento de novos produtos e limitando a capacidade inovadora da empresa. Esta constatação foi a mesma de Moultrie, Clarkson e Probert (2007) em seis casos analisados junto a PMEs, em que a maior preocupação era de natureza gerencial, ou seja, relacionados ao alcance de metas de desenvolvimento dos projetos em termos de tempo e custo.

Ambas as empresas não utilizam sistema de medição de desempenho formal para gestão da inovação. Desta forma, não há períodos pré-estabelecidos para mensuração ou análise, sendo estes realizados por solicitação da diretoria ou quando se identifica algum problema recorrente em projetos em um curto espaço temporal.

Os indicadores eventualmente utilizados são básicos e normalmente de saída de processo - ou resultado -, como número de novos produtos e faturamento, por exemplo. Indicadores de entrada e de processo normalmente são pouco utilizados. Os indicadores de processo verificados referem-se ao número de projetos em cada 
uma das suas fases de desenvolvimento - apresentadas como fluxos de processo neste capítulo. A pesquisa de Adams, Bessant e Phelps (2006) traz esta mesma constatação, afirmando que a mensuração do desempenho da inovação não aparenta caminhar em conjunto com as práticas de gestão e, quando ocorre, focam-se somente nos indicadores de saída (ou resultado).

Não foram evidenciados monitoramento ou controle sobre tempo desenvolvimento e, tampouco, tentativas de mensuração de custos ou orçamento disponível. No estudo de Moultrie, Clarkson e Probert (2007), com seis estudos de casos em PMEs industriais, também se evidenciou a lacuna das empresas na mensuração e controle de custos de desenvolvimento.

Por fim, ressalta-se que os indicadores, em momentos específicos utilizados pelas empresas analisadas, não geraram aprendizado. Em outros termos, não nortearam ações para melhoria contínua da gestão da inovação ou do processo de desenvolvimento de novos produtos.

O próximo capítulo traz a abordagem e os resultados da fase III de campo, em que a partir da literatura teórica e dos aprendizados obtidos nas fases anteriores, pode-se construir uma ferramenta mais adequada para a gestão da inovação de produtos em PMEs industriais tradicionais. Na sequência, o modelo proposto é testado por meio de verificação de aderência em três casos selecionados. 


\section{FASE III - CONSTRUÇÃO DE FERRAMENTA E ADERÊNCIA}

A fase III visa desenvolver ferramenta de fácil entendimento e aplicação por PMEs industriais tradicionais de média ou baixa intensidade tecnológica a partir dos aprendizados obtidos nas fases I e II desta pesquisa e da revisão bibliográfica. A primeira parte deste capítulo traz o processo de construção do modelo proposto e, a segunda, a verificação de sua aderência a partir de três empresas selecionadas.

\subsection{CONSTRUÇÃO DA FERRAMENTA}

A partir da revisão teórica e dos resultados obtidos nas fases I e II, torna-se clara a necessidade de uma ferramenta simples e facilmente aplicável para o perfil de empresas analisado, que possa trazer benefícios ao desenvolvimento de novos produtos e permita uma gestão da inovação eficiente. Ao mesmo tempo que deva auxiliar o processo de inovação de produtos, os indicadores propostos não podem dispender de muito tempo para medição, controle e acompanhamento para que possa ser implementado.

Para construção desta ferramenta, adotou-se como base os modelos da literatura descritos por Goffin e Mitchell (2005) e Adams, Bessant e Phelps (2006). O primeiro por oferecer uma lista exaustiva de indicadores relacionando-os às etapas do processo de inovação. O segundo, por ter realizado revisão bibliográfica de modelos pregressos e sintetizá-los em dimensões a serem consideradas para mensuração do desempenho inovador. A partir das dimensões chave e indicadores propostos pelas duas pesquisas, exploraram-se os indicadores que seriam úteis e de fácil aplicação pelas pequenas e médias indústrias representadas neste estudo.

Conforme abordado na seção de revisão bibliográfica, Goffin e Mitchell (2005) organizaram os indicadores por dimensões e em medidas de entrada, processo e de saída. As dimensões utilizadas foram financeiras, perspectiva do cliente, recursos, eficiência do processo e aprendizado. A dimensão de medidas específicas para serviços foi excluída por esta pesquisa ter o recorte em indústrias e no desenvolvimento de produtos. 
A partir dos aprendizados gerados durante a fase II, os indicadores sugeridos por eles foram separados entre fácil aplicabilidade e difícil aplicabilidade tendo em vista as empresas estudadas. O resultado desta divisão é apresentado na tabela a seguir:

Quadro 10 - Indicadores de fácil e difícil aplicabilidade para empresas estudadas

\begin{tabular}{|c|c|}
\hline Fácil aplicabilidade & Difícil aplicabilidade \\
\hline \multicolumn{2}{|l|}{ Financeiras } \\
\hline $\begin{array}{l}\text { Percentual do faturamento investido ou } \\
\text { orçamento disponível }\end{array}$ & Investimento em aquisição de tecnologias \\
\hline $\begin{array}{l}\text { Projetos atrasados ou cancelados por falta de } \\
\text { recursos }\end{array}$ & $\begin{array}{l}\text { Economia por terceirização de parte do } \\
\text { processo }\end{array}$ \\
\hline Custo médio dos projetos & Melhoria de qualidade proveniente de inovações \\
\hline Faturamento proveniente de novos produtos & Retorno sobre o investimento \\
\hline \multicolumn{2}{|l|}{ Perspectiva do cliente } \\
\hline $\begin{array}{l}\text { Número de novos produtos comparados aos } \\
\text { concorrentes }\end{array}$ & Mix de projetos por direcionadores estratégicos \\
\hline $\begin{array}{l}\text { Índices de satisfação do consumidor (mediante } \\
\text { pesquisa) }\end{array}$ & $\begin{array}{l}\text { Velocidade de introdução de novos produtos no } \\
\text { mercado (percepção de novidade) }\end{array}$ \\
\hline \multicolumn{2}{|l|}{ Recursos } \\
\hline Número de funcionários envolvidos & Eficiência no relacionamento externo à empresa \\
\hline \multicolumn{2}{|l|}{ Número de funcionários treinados } \\
\hline \multicolumn{2}{|l|}{ Ideias geradas } \\
\hline \multicolumn{2}{|l|}{ Eficiência do processo } \\
\hline Horas trabalhadas por projeto & Ponto de equilíbrio \\
\hline Tempo para lançamento & Número de patentes \\
\hline \multicolumn{2}{|l|}{ Número de funcionários envolvidos } \\
\hline \multicolumn{2}{|l|}{ Aprendizado } \\
\hline Realização de pós projeto & Melhorias nos processos de inovação \\
\hline
\end{tabular}

Fonte: Elaboração própria.

Adams, Bessant e Phelps (2006), a partir de uma revisão de literatura em modelos de gestão de inovação e auditorias, propõem um quadro para avaliação do desempenho considerando sete dimensões: entradas, gestão de conhecimento, estratégia de inovação, organização e cultura, gestão de portfólio, gestão de projetos e comercialização. Novamente, a partir dos aprendizados gerados durante a fase II, as dimensões sugeridas por eles foram separadas quanto a facilidade de aplicação pelas empresas estudadas. $O$ resultado é apresentado no quadro a seguir. Os textos entre 
parênteses indicam como a dimensão foi utilizada em termos de indicador para a ferramenta proposta.

Quadro 11 - Dimensões de fácil e difícil aplicabilidade para empresas estudadas

\begin{tabular}{|c|c|}
\hline Fácil aplicação & Difícil aplicação \\
\hline \multicolumn{2}{|l|}{ Entradas } \\
\hline Pessoas envolvidas no processo & Ferramentas \\
\hline \multicolumn{2}{|l|}{ Recursos físicos e financeiros } \\
\hline \multicolumn{2}{|l|}{ Gestão de conhecimento } \\
\hline Geração de ideias (número de ideias geradas) & Fluxos de informação \\
\hline \multicolumn{2}{|l|}{ Conhecimento (número de treinamentos) } \\
\hline \multicolumn{2}{|l|}{ Estratégia de inovação } \\
\hline & Orientação estratégica \\
\hline & Liderança estratégica \\
\hline \multicolumn{2}{|l|}{ Organização e cultura } \\
\hline Estrutura (número de pessoas envolvidas) & Cultura \\
\hline \multicolumn{2}{|l|}{ Gestão de portfólio } \\
\hline & Balanceamento risco-retorno \\
\hline & Ferramentas de otimização \\
\hline \multicolumn{2}{|l|}{ Gestão de projetos } \\
\hline \multirow[t]{3}{*}{$\begin{array}{l}\text { Eficiência de projetos (considerado em termos } \\
\text { de custos, horas, atrasos e cancelamentos) }\end{array}$} & Ferramentas de gestão de projetos \\
\hline & Comunicação \\
\hline & Colaboração \\
\hline \multicolumn{2}{|l|}{ Comercialização } \\
\hline \multirow[t]{2}{*}{$\begin{array}{l}\text { Pesquisa de mercado (escala para mensuração } \\
\text { de satisfação do cliente) }\end{array}$} & Teste de mercado \\
\hline & Marketing e vendas \\
\hline
\end{tabular}

Fonte: Elaboração própria.

A partir da releitura dos textos de Goffin e Mitchell (2005) e Adams, Bessant e Phelps (2006) e dos aprendizados obtidos na fase II, pode-se chegar à ferramenta proposta a ser testada na fase III desta pesquisa. Os indicadores propostos estão organizados nas etapas do processo de inovação de ideação, conversão e difusão propostas por Hansen e Birkinshaw (2007) e divididos entre indicadores de entrada, de processo e de saída (GOFFIN; MITCHELL, 2005). É importante ressaltar que a saída de uma 
etapa se constitui na entrada de outra, ou seja, a saída da etapa de ideação constituise na entrada da etapa de conversão, e a saída desta última na entrada da fase de difusão. A ferramenta desenvolvida é apresentada a seguir:

Figura 14 - Ferramenta desenvolvida para a fase III

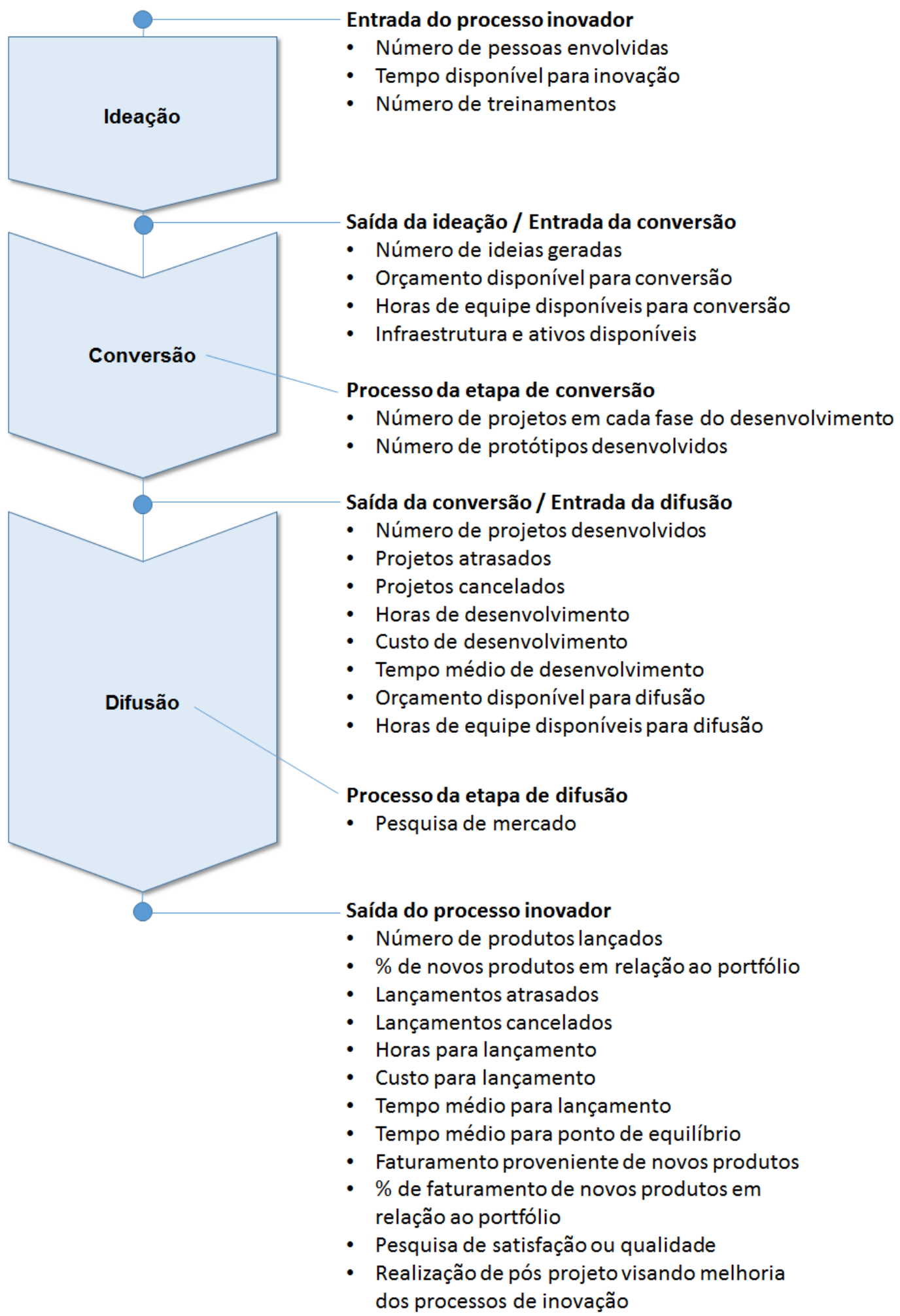

Fonte: Elaboração própria. 
A fase III objetivou a construção de ferramenta para gestão de inovação e a verificação de sua aderência junto a empresas selecionadas. Conforme apresentado na seção anterior, a ferramenta foi construída com base na revisão bibliográfica e nos aprendizados obtidos durante as fases I e II desta pesquisa.

Para verificação de aderência da ferramenta, foram estudados três casos: as mesmas duas empresas analisadas na fase II e uma terceira, a empresa 18 (plásticos). Novamente, a seleção foi realizada em empresas que apresentam processos contínuos de desenvolvimento de novos produtos, que não possuem porte muito pequeno em relação a funcionários e faturamento e pela facilidade de acesso a informações e colaboradores - características identificadas durante os atendimentos do projeto NAGI conduzidos pelo pesquisador.

Assim como na fase II da pesquisa, foram conduzidas entrevistas semiestruturadas e realizadas observações presenciais nas três empresas selecionadas, com objetivo de verificar a aplicabilidade da ferramenta desenvolvida na gestão da inovação das empresas. Considerou-se como critérios importantes a compreensão dos indicadores, a facilidade de implantação e o benefício trazido ao processo pelo acompanhamento e gestão dos indicadores.

O procedimento adotado permitiu a condução do pesquisador orientado a esses critérios principais, porém sem limitar a possibilidade do entrevistado em discutir outros aspectos considerados importantes para a eventual implementação. As entrevistas ocorreram em abril e maio de 2017, sendo realizados dois encontros de aproximadamente duas horas de duração com cada uma das empresas. Novamente foram envolvidos os mesmos interlocutores: gerentes responsáveis pelo desenvolvimento de novos produtos nas três PMEs. É importante lembrar que o pesquisador já possuía conhecimento prévio das empresas decorrente dos atendimentos e acompanhamentos do projeto NAGI realizados - descritos na fase I -, além de documentos que foram coletados e gerados no mesmo período. Adicionalmente, duas das três empresas analisadas na fase III haviam sido recentemente contatadas na fase II.

O roteiro utilizado foi pautado nos indicadores propostos na ferramenta, apresentada na figura 14, inclusive na sequência e organizados pelos processos de inovação: 
geração de ideias, conversão e difusão. Primeiramente foram abordados os indicadores de "entrada do processo inovador", depois os referentes à "saída da ideação / entrada da conversão", e assim sucessivamente. Os indicadores eram explicitados pelo pesquisador, discutia-se como poderiam ser mensurados e depois as PMEs ofereciam suas visões em relação à facilidade de entendimento do indicador, facilidade de aplicação e implementação e percepção de eficácia.

Os três casos estudados são apresentados e analisados a seguir. O terceiro caso, empresa 18 (plásticos), por não ter sido abordado na fase II, inicia-se com breve caracterização da empresa e dos seus processos de desenvolvimento de produtos.

\subsection{CASO 1 - EMPRESA 11 (ILUMINAÇÃO)}

A empresa 11 já foi apresentada na seção 5.1 deste documento. Seguem abaixo suas visões em relação à ferramenta proposta, divididos pelos grupos de indicadores.

\subsubsection{Apreciação geral da ferramenta}

De modo geral, a ferramenta foi considerada pela empresa como simples e de fácil aplicação. Embora existam alguns indicadores mais difíceis de serem monitorados, entendeu-se que o modelo é útil por trazer uma preocupação quanto a mensuração e posterior comparação com o desempenho, uma vez que atualmente praticamente nada é medido.

Foi apontado que, embora o modelo proposto não garanta que a empresa conseguirá inovar, e em que prazo, já que este é um fator crítico para as coleções, a ferramenta permitiria o comparativo periódico de indicadores com ela própria ao longo do tempo, possibilitando uma medida para seu grau de evolução. A lacuna seria que, em uma

primeira rodada, não seria possível dizer se a empresa estaria bem ou ruim quanto a aspectos de inovação de produtos. Outro apontamento refere-se a inexistência de indicadores de processo para a etapa de ideação. 


\section{$\underline{6.2 .2 \text { Indicadores de entrada do processo inovador }}$}

A empresa considerou a identificação de pessoas envolvidas no processo de inovação de fácil aplicação, uma vez que sua estrutura é pequena. Algo que seria mais difícil seria a apuração de horas das pessoas envolvidas, uma vez que a função inovação na empresa é dividida entre pessoas que têm este mandato como função principal área de desenvolvimento de coleções e novos produtos - e pessoas que participam do processo sugerindo ideias, sem fazer parte do processo formal de inovação. Podese citar como exemplos a área comercial, que eventualmente traz informações relevantes sobre as lojas ou o mercado em geral, ou os instaladores, que trazem uma visão prática do uso dos produtos a partir de sua experiência junto a clientes.

O tempo disponível para inovação foi considerado de fácil monitoramento para aqueles que possuem dedicação integral a esta função. Como já mencionado, para outros colaboradores, poder-se-ia acompanhar por períodos dedicados a reuniões com equipes de desenvolvimento de novos produtos. Eventualmente, a adoção de reuniões sistemáticas poderia auxiliar o processo e também o acompanhamento deste indicador.

Quanto a conhecimento, evidenciou-se uma dificuldade em distinguir treinamentos que contariam como indutores de inovação dos que não contariam. No entanto, controlar as horas de treinamento anual por pessoas seria interessante para gestão interna.

\section{$\underline{6.2 .3 \text { Indicadores de saída da ideação / entrada da conversão }}$}

Os indicadores foram considerados aplicáveis e de fácil mensuração. Única limitação apontada está na identificação Maior problema identificado está em no que tange às horas de equipe disponíveis para conversão. Como a estrutura é pequena, alguns recursos humanos são compartilhados em outras atividades, até mesmo sem previsão. Ou seja, mesmo que não seja sua atribuição funcional, pode ser solicitado que o colaborador direcione seus esforços para resolver um problema ou dar um esclarecimento apoiando a área comercial ou industrial, por exemplo. 


\section{$\underline{6.2 .4 \text { Indicadores de processo da etapa de conversão }}$}

Os indicadores sugeridos foram considerados de fácil aplicação e auxiliarão na gestão do processo. Contudo, a empresa aponta que os métodos de avaliação e priorização dos projetos do portfólio ainda não estão claros, sobretudo quanto a quais dimensões que devem ser consideradas. O maior desafio nesta etapa estaria em criar um sistema baseado em critérios, notas e pesos para que as prioridades fossem automatizadas.

\subsubsection{Indicadores de saída da conversão / entrada da difusão}

O conjunto de indicadores proposto para essa etapa agregariam bastante valor à gestão da inovação da empresa na visão dela. Em se tratando de produtos, controlar o número de projetos em cada status é simples. A maior dificuldade foi vislumbrada nos indicadores de horas e custo de desenvolvimento. Como já citado, a função inovação pode estar relacionada a horas de diversas pessoas, sendo umas dedicadas integralmente à função e outras não. O tempo de desenvolvimento em dias, por exemplo, seria uma métrica mais adequada que auxiliaria à gestão. $\mathrm{O}$ custo de desenvolvimento é igualmente complexo, pois está atrelado à quantidade de horas trabalhadas.

Orçamento seria um indicador interessante a ser acompanhado pela empresa, pois além de avaliar o montante, poder-se-ia refletir quanto a sua destinação, indicando as melhores estratégias - do ponto de vista de eficácia e eficiência - para marketing e lançamento de produtos ao longo do tempo.

As horas de equipe disponíveis para difusão é relativamente simples no caso analisado, pois envolve equipe interna dedicada a esta função, isolada na área comercial. 


\section{$\underline{6.2 .6}$ Indicadores de processo da etapa de difusão}

Indicador foi apontado como interessante se aplicado por meio de pesquisa de mercado através das lojas, instaladores e influenciadores. Pode-se identificar atributos chave para os produtos e criar uma escala para cada um deles, como de um a cinco, por exemplo.

\section{$\underline{6.2 .7 \text { Indicadores de saída do processo inovador }}$}

Os indicadores de saída foram considerados de fácil entendimento e implementação. No caso específico desta empresa, o número de produtos lançados poderia até ser classificado em first to market, fast follower e me-too products, devido à facilidade de aplicação neste setor.

O faturamento, embora seja um indicador fundamental, possui uma limitação de levar um certo tempo até que seja devidamente apurado. Portanto, deve ser feito em período diferente de outras mensurações. A satisfação do cliente pode ser medida através de pesquisa de atributos chave em escala de um a cinco junto aos clientes por meio das lojas e dos instaladores.

A empresa destacou que a simples verificação quanto a se houve - ou não - pós projeto, visando a melhoria dos processos de inovação, seria positiva, ainda que não necessariamente gere resultados efetivos. A simples busca por evolução já é um valor para o desenvolvimento de novos produtos da empresa.

Novamente, apontou-se a dificuldade em mensurar horas e custo para lançamento. Se considerado o indicador em termos de dias seria mais aderente à realidade da empresa. 


\subsection{CASO 2 - EMPRESA 2 (AUTOPEÇAS)}

A empresa 2 já foi apresentada na seção 5.2 deste documento. Seguem abaixo suas visões em relação à ferramenta proposta, divididos pelos grupos de indicadores.

\subsubsection{Apreciação geral da ferramenta}

A empresa indicou que a ferramenta desenvolvida é aderente à sua realidade, uma vez que catalisa um processo de mensuração e verificação ao longo do tempo, que por si traz provocações à organização e incita a discussão de práticas que poderiam trazer melhoria aos indicadores. As métricas foram consideradas de fácil entendimento, aplicação e mensuração, algo bastante positivo para este estudo. Embora não garanta os resultados efetivos da inovação em produtos, acredita-se que o simples ato de medir e verificar posteriormente gera reflexão para o aprimoramento contínuo. No entanto, a empresa não sabe afirmar se os fatores sugeridos são realmente os que mais impactam a geração de novos produtos.

\subsubsection{Indicadores de entrada do processo inovador}

Os indicadores de entrada do processo inovador foram considerados simples e aplicáveis. O número de pessoas envolvidas é de fácil verificação, pois o processo de cotação e desenvolvimento se refere a um número limitado de pessoas. A verificação de horas empregadas, apesar de não trivial, seria possível de ser estimado pelo método de trabalho da empresa. Além disso, há diversas pessoas que praticamente todas suas atividades estão voltadas à inovação de produtos. O número de treinamentos em assuntos que trariam ganhos à gestão e ao processo de inovação também seriam de fácil levantamento. 


\subsubsection{Indicadores de saída da ideação / entrada da conversão}

Em geral, os indicadores foram compreendidos pela empresa e considerados de fácil aplicação. O número de ideias geradas costuma ser dado pelas demandas dos clientes, mas ainda há iniciativas internas de substituição de produtos, conforme abordado na fase II. As horas disponíveis também é algo possível de ser estimado e mensurado, partindo do tempo total disponível para realizar a entrega do primeiro lote de amostras ao cliente.

A questão dos recursos financeiros para conversão é um tema de complexidade na empresa historicamente. Há uma discussão de até quanto poderia se gastar para enviar uma cotação, sabendo que há o risco de não concluir o pedido. Posteriormente, também há uma lacuna na determinação de orçamento para o desenvolvimento do produto até que ele atinja o resultado adequado, já que os processos para precificação ainda não estão resolvidos internamente. É mais fácil para a empresa atualmente verificar o total gasto após a conclusão do desenvolvimento, comparando este indicador ao longo do tempo e verificando sua evolução de eficiência.

A empresa entende que o indicador de infraestrutura é relevante, porém em seu caso específico há pouca alteração ao longo do tempo. Eventualmente, há alterações em itens associados à área de ferramentaria.

\section{$\underline{6.3 .4 \text { Indicadores de processo da etapa de conversão }}$}

O número de projetos em cada fase do desenvolvimento é de fácil acompanhamento na visão da empresa, bem como o número de protótipos que, para o caso em análise, refere-se às amostras produzidas. O processo de avaliação e priorização pode ser realizado mediante o controle dos prazos de entrega e os valores estimados dos contratos, algo que irá auxiliar a gestão da inovação de produtos. 


\subsubsection{Indicadores de saída da conversão / entrada da difusão}

De modo geral, os indicadores foram considerados de fácil implementação. Os indicadores relacionados a números de projetos não necessitariam de nenhuma adaptação no processo, pois poderiam ser facilmente coletados.

Quanto a horas de desenvolvimento, seria mais fácil considerar um prazo de desenvolvimento em dias, com determinada equipe envolvida. Considerar horas individuais de pessoas, tendo idas e vindas no processo seria de difícil implementação atualmente, ainda que pudesse ser resolvida com alterações no método de trabalho o que talvez não valha a pena. O tempo médio de desenvolvimento, com aproximação em dias, já seria de valia para a gestão a longo prazo. Assim, o custo real de desenvolvimento é igualmente complexo, pois além das horas de equipe, há custo de materiais para amostras.

\subsubsection{Indicadores de processo da etapa de difusão}

O conceito de difusão tradicional não se aplica ao contexto da empresa. O processo de desenvolvimento de novo produto é iniciado quando já há demanda, para um cliente específico que aprovou o orçamento. Assim, quando ele testa e aprova o produto - por meio da amostra enviada -, finaliza-se o contrato e se inicia a produção em escala.

\subsubsection{Indicadores de saída do processo inovador}

Novamente, de modo geral, os indicadores foram apontados como de fácil entendimento e aplicação. No entanto, a apuração de horas e custos é mais complexo. $\mathrm{O}$ indicador de tempo médio poderia ser adaptado para dias e eventualmente semanas para os desenvolvimentos de produto mais complexos. No contexto da empresa, esta adaptação faria sentido e já traria ganhos suficientes para a gestão do processo, atualmente pouco baseado em indicadores. 
Pela natureza do setor que atua, o indicador de qualidade poderia ser traduzido em aspectos técnicos que poderiam ser mensurados com testes mecânicos e de tolerância dimensional, por exemplo. Quanto a indicador de satisfação de clientes, a empresa não sabe se seria necessário, pois uma vez a amostra estando dentro de padrões de qualidade especificados no orçamento e aprovada pelo cliente, o desafio de desenvolvimento já estaria superado.

\subsection{CASO 3 - EMPRESA 18 (PLÁSTICOS)}

A empresa fabrica produtos de plástico, a partir de tecnologia de injeção plástica e rotomoldagem, sobretudo para o segmento pet - animais de estimação. Entre seus produtos estão casinhas de cachorro, comedouros, bebedouros, frisbees, bandejas para gatos, pás higiênicas, brinquedos e acessórios. Incluem-se diversas variações de formatos, relevos e cores, compondo um mix de aproximadamente duzentas unidades de manutenção de estoque (stock keeping units - SKUs). Os canais comerciais explorados pela empresa são distribuidores, que representa cerca de $80 \%$ do faturamento, e redes varejistas.

A empresa está localizada no interior do estado de São Paulo e conta com cerca de trinta colaboradores, além de equipe comercial comissionada. Atualmente, estuda-se a possibilidade de entrada no segmento de utilidades domésticas e alguns pilotos têm sido realizados neste sentido.

A função inovação em produtos é exercida pelo proprietário e gestor da empresa em conjunto com seu gerente industrial e alguns técnicos considerados mais qualificados, que são emprestados da produção em momentos de ociosidade ou quando há tempo hábil para entrega dos próximos pedidos.

Deve-se notar que o processo de inovação nesta empresa normalmente não se inicia por demanda de clientes ou em períodos pré estabelecidos, mas sim por iniciativa própria em períodos de baixa produtiva ou comercial. 
A ideação normalmente é originada pelo sócio-gestor ou pelo gerente industrial da empresa, na maior parte das vezes a partir da observação de feiras e eventos internacionais, pontos de venda, redes de lojas e internet.

A seleção e priorização dos projetos a serem desenvolvidas não passam por critério formal ou objetivo, basicamente esta etapa é realizada a partir de ajuste mútuo entre proprietário e gerente industrial.

O maior desafio que a empresa enfrenta para a etapa de conversão está na decisão quanto a encomendar a produção do molde, processo realizado por terceiro. Este ferramental consiste em valor relativamente alto para a empresa, e portanto, deve haver uma quantidade de vendas que justifique o investimento. Após confecção do molde, as demais atividades relacionadas ao desenvolvimento são sanadas internamente pela empresa, ajustando a ficha técnica e o processo produtivo.

A difusão, ou lançamento, é realizada pela equipe comercial junto aos parceiros comerciais: distribuidores e redes varejistas. Há pouco investimento em marketing realizado pela empresa, seja para os clientes diretos ou consumidores finais.

Atualmente a empresa não utiliza ferramentas de gestão de inovação e tampouco sistema de medição de desempenho. A seguir são apresentadas suas considerações em relação à ferramenta proposta, divididas pelos grupos de indicadores.

\subsubsection{Apreciação geral da ferramenta}

A empresa considerou que a ferramenta se traduz em grande valia para a sua gestão da inovação, porque juntamente com os indicadores traz um processo a ser minimamente seguido pela organização, o que se entende que irá contribuir para os resultados no longo prazo. A simples preocupação em mensurar indicadores periodicamente, em prazo a ser estabelecido, trará um nível de preocupação maior que o atual para o desenvolvimento de novos produtos.

Os agrupamentos pelas etapas do processo de inovação e os indicadores se mostraram de fácil entendimento e aplicação pela equipe. Há indicadores considerados um pouco mais complexos, como mensuração de tempo e custos, no 
entanto, o uso de simplificações ou de estimativas já auxiliaria nas análises para gestão.

\subsubsection{Indicadores de entrada do processo inovador}

Os indicadores de entrada foram considerados de fácil implementação e úteis para acompanhamento no longo prazo. A simples apresentação da ferramenta gerou uma reflexão de envolver mais pessoas da empresa no processo e destinar seções periódicas para a função inovação, uma vez que estes são indicadores previstos.

A necessidade de treinamentos para a equipe que induzam práticas de inovação e intraempreendedorismo também pode se traduzir em ganhos a médio e longo prazo para a organização.

\section{$\underline{6.4 .3}$ Indicadores de saída da ideação / entrada da conversão}

Os indicadores foram compreendidos e avaliados como de fácil aplicabilidade. Principal provocação gerada neste caso, considerada positiva, foi em relação à necessidade de orçamento para as etapas do processo de desenvolvimento de novos produtos. A adoção da ferramenta exigiria um modelo mais sistemático de destinação de recursos não somente para a função inovação, como para outras funções exercidas dentro da empresa.

A mensuração de horas de equipe para conversão dependeria de controles mais apurados do sistema de planejamento e controle da produção da empresa, mas uma vez sanado este ponto, seria de grande utilidade para a gestão. A separação de horas mensais da fábrica para o desenvolvimento de novos produtos introduziria um desafio positivo para a organização.

\section{$\underline{6.4 .4 \text { Indicadores de processo da etapa de conversão }}$}

Os indicadores sugeridos foram considerados de fácil aplicação e implementação. 


\section{$\underline{6.4 .5}$ Indicadores de saída da conversão / entrada da difusão}

Os indicadores de saída da etapa de conversão foram apontados como claros e agregarão bastante valor à gestão da inovação da empresa na sua visão. Ter a mensuração de projetos por status auxiliarão direcionamentos futuros e o método de priorização de iniciativas futuramente. No entanto, a mensuração do desenvolvimento em tempo ou em horas é difícil para o status atual de gestão operacional da empresa, que divide seus recursos com a função inovação de produtos. Ainda mais complexo seria aferir o custo de desenvolvimento, algo considerado inviável de implementação neste momento.

Refletindo acerca dos indicadores de entrada da etapa de difusão, novamente foi considerada positiva a provocação para ter orçamento destinado ao lançamento e divulgação de novos produtos, além de pré-estabelecer horas de equipe direcionadas a estas atividades.

\subsubsection{Indicadores de processo da etapa de difusão}

Indicador pode ser interessante se acompanhado para os diversos produtos lançados, trazendo melhorias para o processo como um todo, desde a ideação até a difusão. Sua implementação foi considerada simples se aplicados breves questionários junto aos distribuidores e lojistas pela equipe comercial, que deverá ter suas comissões atreladas ao preenchimento das pesquisas de mercado. Há um desafio de elaborar o modelo de pesquisa, identificando as variáveis chave a serem questionadas e monitoradas, mas acredita-se que a metodologia pode trazer grande valor para a organização.

\subsubsection{Indicadores de saída do processo inovador}

Assim como os indicadores de saída da etapa de conversão, os indicadores propostos foram apontados como claros e de grande valor para a gestão da inovação da empresa na sua visão. Contudo, existe a mesma dificuldade na mensuração do 
processo inovador em termos de horas, tempo e custos, por limitações da organização já explicitadas.

Gerou maior discussão o indicador relacionado a satisfação do cliente, ou sua percepção em relação a qualidade dos produtos. Atualmente a empresa possui pouco retorno (feedback) do consumidor final, por ter contato direto apenas com distribuidores e varejistas, e por via de vendedores comissionados. A aproximação com o consumidor final traria informações relevantes para a geração de ideias e para o processo de desenvolvimento de novos produtos da empresa, devendo ser um objetivo a ser alcançado nos próximos meses.

O pós projeto, visando a melhoria contínua do processo de inovação de produtos, também não é realizado e deve ser perseguido pela empresa para sua evolução no mercado a médio e longo prazo.

\subsection{APRENDIZADOS DA FASE III}

A partir dos casos analisados, nota-se que eles possuem resultados semelhantes nos seguintes aspectos:

- Os responsáveis pela função de inovação de produtos julgaram a ferramenta proposta de fácil entendimento, aplicação e implementação, salvo alguns indicadores específicos.

- Foram citadas dificuldades na mensuração e controle de horas dispendidas e no custo das etapas relacionadas ao processo de inovação de produtos.

- A ferramenta traria ganhos à gestão da inovação de produtos por exigir certa disciplina ao criar processos mínimos para mensuração dos indicadores. Adicionalmente, o seu uso provocaria uma reflexão periódica de possibilidades de melhoria no desenvolvimento de novos produtos, que inclusive poderia contar com a participação de colaboradores atualmente não envolvidos no processo. 
Por outro lado, houve divergência nos casos estudados nos seguintes pontos:

- Embora as empresas afirmem que a aplicação da ferramenta melhorará o processo atual, as organizações não souberam dizer se os indicadores propostos são os ideais a serem acompanhados, e nem se foi omitido algum indicador importante à gestão. Outro ponto é a incerteza quanto aos resultados efetivos no médio prazo, como redução do tempo total de desenvolvimento, aumento do número de produtos desenvolvidos e aumento de faturamento.

- Para algumas empresas a etapa de ideação ou de difusão tem menor importância no processo inovador devido à forma como é iniciado, por exemplo, quando ocorre através de demanda do cliente. De todo modo, os indicadores se mostraram úteis mesmo nestes casos, principalmente os relacionados às entradas e saídas das etapas. Os indicadores relacionados à conversão entrada, processo e saída - mostraram-se relevantes em todos os casos.

Durante a condução dos casos, foram identificadas oportunidades de melhoria na ferramenta nos aspectos a seguir:

- Possibilidade de adotar simplificações ou estimativas para aplicação dos indicadores de tempo ou duração das etapas do processo inovador. Poder-seia agregar valor à gestão com o acompanhamento de dias de desenvolvimento, por exemplo, ao invés de exigir processo para controle de horas.

- Desenvolvimento de pelo menos um indicador de processo de fácil aplicação e mensuração para as empresas do perfil estudado na etapa de ideação. 0 número de ideias geradas, por exemplo, é um indicador de saída claro, mas quais os fatores do processo que garantiriam boas ideias - e que fossem mensuráveis?

Assim como na pesquisa de Moultrie, Clarkson e Probert (2007), durante o desenvolvimento do modelo de mensuração foi percebida uma escolha clara entre adotar um conjunto maior de dimensões e indicadores previstos na literatura e o que as empresas conseguiriam absorver e implementar em seus processos. De modo a 
ter uma ferramenta utilizável pelas empresas, traduzida em facilidade de entendimento, aplicação e implementação, potenciais dimensões e indicadores foram removidos, como a escolha realizada por Moultrie, Clarkson e Probert (2007) em seu estudo. Adams, Bessant e Phelps (2006) afirmam que um dos motivos pelos quais as empresas não adotam ferramentas de desempenho de inovação é a complexidade das medidas dos modelos existentes e o seu fraco poder de síntese e empacotamento. Neste sentido, a ferramenta proposta foi bem sucedida.

Contudo, Adams, Bessant e Phelps (2006) debatem sobre o objetivo de um sistema de métricas, que dependeria das necessidades dos usuários em termos de abrangência, tipo de inovação, dados disponíveis e possibilidade de esforço disponível, induzindo à elaboração de um modelo de mensuração mais genérico e menos prescritivo. Segundo os pesquisadores, a tentativa de desenvolver uma ferramenta com muitas especificações, pode incorrer em dois tipos de lacunas: (i) validade, que se refere à insuficiência de evidências de que os indicadores propostos são os mais adequados para o propósito e; (ii) omissão, que ocorre quando dimensões importantes previstas na literatura estão faltando.

Conscientemente, para construção da ferramenta, houve omissão em dimensões previstas na literatura como estratégia de inovação, organização e cultura, gestão do conhecimento e comercialização. Porém, Adams, Bessant e Phelps (2006) reconhecem que são elementos importantes a serem considerados, mas com tratamento complexo do ponto de vista de mensuração de desempenho e aplicação prática.

Desta forma, reforça-se a escolha desta dissertação em propor uma ferramenta prática e aplicável, sem perder elementos importantes e fundamentais estudados na teoria. Como Adams, Bessant e Phelps (2006) mesmo reconhecem, um modelo de mensuração de desempenho mais genérico, embora possa ser mais aplicável a diferentes contextos, possui a limitação de parecer abstrato para o contexto prático, com poucas considerações em relação ao uso das medidas no cotidiano da função inovação das empresas.

Outro ponto a ser destacado é que a ferramenta desenvolvida não teve a percepção negativa de excesso de burocracia, citada como lacuna no modelo desenvolvido por 
Moultrie, Clarkson e Probert (2007). Nesse estudo, os pesquisadores citam que as empresas tiveram que encontrar o equilíbrio entre controles gerenciais e burocracia.

Em relação à aplicação dos indicadores de inovação, Moultrie, Clarkson e Probert (2007) também evidenciaram a dificuldade das organizações na mensuração dos custos de desenvolvimento em sua pesquisa. Outro ponto desse estudo é que os indivíduos da mesma empresa podem ter grandes diferenças de percepção no que tange ao desempenho da função inovação e de seus resultados futuros. Na presente pesquisa não foi possível constatar isto, uma vez que os interlocutores eram sempre os mesmos durante as fases de campo.

Nos casos analisados, houve certa insegurança das empresas quanto a como aprimorar a gestão da inovação em produtos e seus processos após a mensuração dos indicadores. A mesma preocupação aparece na pesquisa de Chiesa, Coughlan e Voss (1996), que discutem que o modelo desenvolvido identifica eventuais problemas do estado atual e saltos necessários para o cenário desejado, mas não identifica as causas das lacunas e não prescreve a definição de planos de ação para melhoria. Adams, Bessant e Phelps (2006) também tratam a questão, afirmando que o modelo permite que cada equipe responsável pela gestão identifique lacunas, fraquezas e deficiências e reflita sobre potenciais de melhoria. As soluções, portanto, devem ser encontradas especificamente pelas equipes de cada uma das empresas. Adicionalmente, não faz sentido buscar comparativos para os indicadores que não os da própria empresa. Em outras palavras, a comparação deve ser feita para a mesma organização ao longo do tempo.

Por fim, quanto ao resultado efetivo da inovação após implantação de modelos de mensuração, Adams, Bessant e Phelps (2006) lembram que a capacidade das organizações de inovar depende de múltiplos fatores. Não se devem somente à organização e aspectos internos, como a implantação da ferramenta proposta, mas também aos relacionados ao ambiente de mercado em que a empresa se insere.

O próximo capítulo traz as conclusões e considerações finais do trabalho, em que é conduzida a discussão sobre os aprendizados, as limitações e as oportunidades de pesquisa no assunto. 


\section{CONCLUSÃO E CONSIDERAÇÕES FINAIS}

Motivada pela constatação de que há peculiaridades na gestão da inovação de produtos de pequenas e médias empresas e que a maioria da pesquisa no tema falha em distinguir grandes e pequenas empresas (MOULTRIE; CLARKSON; PROBERT, 2007), esta dissertação teve como recorte as pequenas e médias indústrias estabelecidas pertencentes a setores de baixa ou média intensidade tecnológica.

Mais especificamente, a questão central de pesquisa que se abordou foi "Quais os indicadores de inovação mais adequados para PMEs industriais tradicionais, de setores de média ou baixa intensidade tecnológica?"

Para apoiar a discussão, utilizou-se principalmente como referenciais teóricos a visão da inovação como processo (HANSEN; BIRKINSHAW, 2007; GOFFIN; MITCHELL, 2005), as dimensões relevantes para sistema de mensuração de desempenho e as auditorias de inovação de Goffin e Mitchell (2005) e Adams, Bessant e Phelps (2006).

Para a abordagem de pesquisa adotou-se estudos de caso, sendo o processo metodológico utilizado norteado pelas diretrizes propostas por Eisenhardt (1989). A pesquisa foi conduzida em três fases, com objetivos distintos:

- Fase I: caracterizada pela compreensão de aspectos gerais da gestão da inovação em pequenas e médias indústrias tradicionais, foi conduzida junto a empresas selecionadas atendidas pelo NAGI.

- Fase II: conduzida a partir de dois estudos de caso, teve como objetivo a compreensão do processo de inovação e sua gestão, além de identificar a utilização de sistemas de gestão e indicadores utilizados por estas PMEs.

- Fase III: objetivou a construção de ferramenta para gestão de inovação, a partir dos aprendizados das fases I e II e de indicadores previstos na literatura, e sua posterior verificação de aderência junto a PMEs selecionadas.

A partir dos resultados obtidos na fase II, observou-se que a fase de conversão é a de maior desafio para a inovação de produtos nas PMEs analisadas, tendo como parâmetro o modelo de processo de inovação proposto por Hansen e Birkinshaw (2007). Notam-se problemas típicos de gestão de projetos, que acarretam em idas e 
vindas no processo, gerando atrasos no tempo total de desenvolvimento de novos produtos e limitando a capacidade inovadora da empresa. Esta constatação foi a mesma de Moultrie, Clarkson e Probert (2007) nos seis casos analisados junto a PMEs, em que a maior preocupação era de natureza gerencial, ou seja, relacionados ao alcance de metas de desenvolvimento dos projetos em termos de tempo e custo.

Ainda na fase II, evidenciou-se que os indicadores normalmente utilizados pelas pequenas e médias indústrias tradicionais estudadas, de média ou baixa capacidade tecnológica, são básicos e usualmente de resultado, como número de novos produtos desenvolvidos e faturamento proveniente de novos produtos. A pesquisa de Adams, Bessant e Phelps (2006) trouxe esta mesma constatação, afirmando que a mensuração do desempenho da inovação não aparenta caminhar em conjunto com as práticas de gestão e, quando ocorre, focam-se somente nos indicadores de saída (ou resultado).

Pelo fato das empresas analisadas na fase II da pesquisa não utilizarem sistema de medição de desempenho formal para gestão da inovação de produtos, fez-se sentido propor ferramenta mais adequada para organizações deste perfil. Critérios importantes para o desenvolvimento foram fácil entendimento, aplicação e implementação, abordados na fase III. Para tal propósito utilizaram-se como referências teóricas os modelos de Goffin e Mitchell (2005) e Adams, Bessant e Phelps (2006).

Assim como na pesquisa de Moultrie, Clarkson e Probert (2007), durante o desenvolvimento do modelo de mensuração foi percebida uma escolha clara entre adotar um conjunto maior de dimensões e indicadores previstos na literatura e o que as empresas conseguiriam absorver e implementar em seus processos. Optou-se por construir uma ferramenta utilizável pelas empresas, mesmo que, conscientemente se pudesse incorrer em lacunas previstas por Adams, Bessant e Phelps (2006), como validade e omissão de medidas. Os mesmos pesquisadores reconhecem que um modelo de mensuração de desempenho mais genérico, embora possa ser mais aplicável a diferentes contextos, possui a limitação de parecer abstrato para o contexto prático, com poucas considerações em relação ao uso das medidas no cotidiano da função inovação das empresas. Neste sentido, considera-se que a ferramenta proposta foi bem sucedida. 
Assim, entende-se que esta dissertação cumpriu seu papel em discutir a questão central de pesquisa, trazendo elementos para a discussão teórica sobre o assunto, contribuindo tanto para a finalidade acadêmica quanto prática da indústria. Foi possível sintetizar múltiplas fontes de conhecimento para criar um modelo útil para PMEs industriais tradicionais, de média ou baixa intensidade tecnológica, que pelos casos analisados se mostrou aderente à realidade das organizações estudadas. Reconhece-se que a disciplina necessária para executar processos mínimos para mensuração dos indicadores já trará ganhos à gestão da inovação de produtos. Adicionalmente, o uso da ferramenta provocaria uma reflexão periódica de possibilidades de melhoria no desenvolvimento de novos produtos e seus processos.

Em relação à aplicação dos indicadores de inovação propostos, houve maior dificuldade das organizações quanto aos aspectos de mensuração de custos de desenvolvimento de novos produtos, também evidenciados na pesquisa de Moultrie, Clarkson e Probert (2007).

Nos casos analisados, houve certa insegurança das empresas quanto a como aprimorar a gestão da inovação em produtos e seus processos após a mensuração dos indicadores. Chiesa, Coughlan e Voss (1996) e Adams, Bessant e Phelps (2006) abordam esta questão, pontuando que o modelo desenvolvido identifica eventuais problemas do estado atual e saltos necessários para o cenário desejado, mas não identifica as causas das lacunas e não prescreve a definição de planos de ação para melhoria. As soluções, portanto, devem ser encontradas especificamente pelas equipes de cada uma das empresas. A ferramenta consiste em um primeiro passo para aprendizado e aprimoramento da gestão da inovação de produtos nas organizações.

Infelizmente, por questões de duração do programa de mestrado, não foi possível testar efetivamente se o sistema de indicadores proposto foi efetivo em aprimorar os resultados finalísticos da gestão da inovação nas empresas. Assim, apenas se testou a sua aderência a implantação e se a percepção dos gestores responsáveis por desenvolvimento de novos produtos é positiva quanto a benefícios para as suas respectivas organizações. Contudo, Adams, Bessant e Phelps (2006) lembram que a capacidade das organizações de inovar depende de múltiplos fatores. Não se devem somente à organização e aspectos internos, como a implantação da ferramenta 
proposta, mas também aos relacionados ao ambiente de mercado em que a empresa se insere.

Deve-se ressaltar que a pesquisa tem limitações quanto a generalização dos resultados a outras pequenas e médias indústrias tradicionais pelo número limitado de casos estudados, não sendo prudente afirmar que os resultados seriam os mesmos para todo este universo. Adicionalmente, pode-se argumentar que as empresas participantes do NAGI teriam um perfil específico por estarem buscando aprimoramento no tema e terem natureza similares quanto aos processos de gestão da inovação ou de desenvolvimento de novos produtos. No entanto, ainda que não resolva a questão, em pesquisa quantitativa realizada por Reis e Salerno (2015) com 335 micro e pequenas indústrias paulistas participantes do Programa de Qualificação para Exportação (PEIEX), notam-se desafios e resultados similares de desempenho em desenvolvimento de produtos e gestão da inovação.

De todo modo, por esses pontos apresentados, cabe o aprofundamento da pesquisa neste assunto com outros perfis de pequenas e médias empresas ou com amostra maior em abordagem quantitativa. Ao término da fase III, por exemplo, observou-se que os casos estudados 1 e 3 possuíam processo de inovação tradicional, enquanto que o caso 2, processo de pedido fechado, segundo Salerno et al. (2015). Este recorte, portanto, associado a como o processo de inovação é iniciado na organização, seria um exemplo interessante de evolução da pesquisa. Ainda, seria de grande valia a utilização de recortes setoriais ou de fatores contingenciais.

Ressalta-se como futuras oportunidades de pesquisa: (i) a abrangência do estudo em PMEs com diferentes recortes, como setor e fatores de contingência; (ii) a efetividade de resultados em aplicação da ferramenta desenvolvida; (iii) os aprendizados para o processo inovador, que consistem na realimentação do fluxo; (iv) os diferentes objetivos em utilizar sistemas de mensuração de desempenho de inovação em PMEs e; (v) a discussão de sistemas de indicadores em PMEs de maneira mais ampla, com dimensões importantes não contempladas no modelo desenvolvido pela dificuldade de mensuração e aplicação, como estratégia de inovação, organização e cultura, gestão do conhecimento e comercialização. 


\section{REFERÊNCIAS}

ADAMS, R.; BESSANT, J.; PHELPS, R. Innovation management measurement: a review. International Journal of Management Reviews, v. 8, n.1, p. 21-47, 2006.

AMIDON ROGERS, D. M. The challenge of fifth generation R\&D. Research Technology Management, n. 39, p. 33-41, 1996.

ANDERSON, P. Decision making by objection and the Cuban missile crisis. Administrative Science Quarterly, n. 28, p. 201-222, 1983.

ANDREASSI, T. Estudo das relações entre indicadores de P\&D e indicadores de resultado empresarial em empresas brasileiras. 1999. Tese de Doutorado Faculdade de Economia, Administração e Contabilidade, Universidade de São Paulo, São Paulo, 1999.

ANDRIES, P.; CZARNITZKI, D. Small firm innovation performance and employee involvement. Small Business Economics, n. 43, p. 21-38, 2014.

AUDRETSCH, D., VAN DER HORST, R., KWAAK, T., THURIK, R. Annual report on EU small and medium-sized enterprises. EIM Business \& Policy Research, 2009.

BARCLAY, I. The new product development process: improving the process of new product development. R\&D Management, n. 4, p. 307-317, 1992.

BECATTINI, G. Flourishing small firms and the re-emergence of industrial districts. In: ICSB 1999 World Conference. Washington: ICSB, 1999.

BERENDS, H., JELINEK, M., REYMEN, I., STULTIENS, R. Product innovation processes in small firms: combining entrepreneurial effectuation and managerial causation. Journal of Product Innovation Management, v. 31, n.3, p.616-635, 2014.

BERTAZI, L. E. A.; SALERNO. M. S. Diagnóstico da capacidade inovadora de pequenas e médias indústrias brasileiras. In: XXII SIMPÓSIO DE ENGENHARIA DE PRODUÇÃO, 2015, Bauru. Anais eletrônicos... Bauru: SIMPEP, 2015.

BLOCK, Z.; MACMILLAN, I. C. Milestones for sucessful venture planning. Harvard Business Review, v. 63, n.5, p.184-196, 1985. 
BOOZ ALLEN HAMILTON. Smart spenders - the global innovation 1000. Booz Allen Hamilton, 2006.

BOSTON CONSULTING GROUP. Innovation 2006. The Boston Consulting Group, 2006.

BOSTON CONSULTING GROUP. The most innovative companies 2015: four factors that differentiate leaders. The Boston Consulting Group, 2015.

BREMSER, W. G.; BARSKY, N. P. Utilizing the balanced scorecard for R\&D performance measurement. R\&D Management, v.34, n.3, p.229-238, 2004.

BROWN, M. G.; SVENSON, R. A. Measuring R\&D productivity: the ideal system measures quality, quantity and cost, is simple, and emphasizes evaluation of R\&D outcomes rather than behaviors. Research Technology Management, v.41, n.6, 1988.

CANTÚ, S. O.; ZAPATA, A. R. P. Qué es la gestión de la innovación y la tecnologia? Journal of Technology Management \& Innovation, p.64-82, 2006.

CHIESA, V.; COUGHLAN, P.; VOSS, C. Development of a technical innovation audit. Journal of Product Innovation Management, n. 13, p. 105-136, 1996.

CHIESA, V.; MASELLA, C. Searching for an effective measure of R\&D performance. Management Decision, v.34, n.7, p.49-57, 1996.

CHIESA, V. et al. Designing a performance measurement system for the research activities: a reference framework and an empirical study. Journal of Engineering and Technology Management, v.25, p.213-226, 2008.

CHRISTENSEN, C. M. The innovator's dilemma: the revolutionary national bestseller that changed the way we do business. New York: HarperBusiness, 2002.

COLLIER, D. W. Measuring performance of R\&D departments. Research Management, v. 20, n. 2, 1977.

COOK, L. How to make R\&D more productive. Harvard Business Review, p.145-153, July-August, 1966. 
COOPER, R. G. New products: what distinguishes the winners. Research Technology Management, Nov-Dez, 1990.

COOPER, R. G. Perspective: The stage-gate idea-to-launch process - update, what's new, and NexGen systems. Journal of Product Innovation Management, vol. 25, p.213-232, 2008.

CORDERO, R. The measurement of innovation performance in the firm: an overview. Research Policy, v.19, n.2, p.185-192, 1990.

DE BRENTANI, U. Sucess factors in developing new business services. European Journal of Marketing, n. 25, p. 33-60, 1991.

DI BENEDETTO, C. A. Identifying the key sucess factors in new product launch. Journal of Product Innovation Management, n. 16, p. 530-544, 1996.

DOSI, G. The nature of the innovative process. London: Pinter Publishers, 1988.

EISENHARDT, K. M. Building theories from case study research. Academy of Management Review, v. 14, n. 4, p. 532-550, 1989.

ERNST, H. Sucess factors of new product development: a review of the empirical literature. International Journal of Management Reviews, n. 4, p. 1-40, 2002.

FIEGENBAUM, A.; KARNANI, A. Output flexibility: a competitive advantage of small firms. Strategic Management Journal, n. 12, pg. 101-114, 1991.

FORSMAN, H. Balancing capability building for radical and incremental innovations. International Journal of Innovation Management, p. 501-520, 2009.

FOSTER, R. N. et al. Improving the return in R\&D. Research Management, v.28, n.1, 1985.

FRANCESCHINI, F. et al. Management by measurement: designing key indicators and performance measurement systems. Springer, 2007.

FRATTINI, F. et al. Towards a system of performance measuers for research activities: nikem research case study. International Journal of Innovation Management, v.10, n.4, p.425-454, 2006. 
GALBRAITH, J. R. Designing complex organizations. Addison-Wesley, Reading, MA, 1973.

GALUNIC, D. C.; EISENHARDT, K. M. Renewing the strategy structure performance paradigm. Research Organization Behaviour, v. 16, p. 215-255, 1994.

GEE, R. E. A method for relating research to corporate goals. Research Management, v. 18, n. $6,1975$.

GERSICK, C. Time and transition in work teams: toward a new model of group development. Academy of Management Journal, n. 31, p. 9-41, 1988.

GLASER, B.; STRAUSS, A. The discovery of grounded theory: strategies of qualitative research. London: 1967.

GLOBE, S.; LEVY, G. W.; SCHWARTZ, C. M. Key factors and events in the innovation process. Research Management, n. 16, p. 8-15, 1973.

GOFFIN, K.; MITCHELL, R. Innovation management: strategy and implementation using the pentathlon framework. Palgrave Macmillan, 2005.

GRIFFIN, A. PDMA research on new product development practices: updating trends and benchmarking best practices. Journal of Product Innovation Management, $n$. 14, p. 429-458, 1997.

GRIFFIN, A.; PAGE, A. L. An interim report on measuring product development success and failure. Journal of Product Innovation Management, v.10, p.291-308, 1993.

GRIFFIN, A.; PAGE, A. L. PDMA success measurement project: recommended measures for product development success and failure. Journal of Product Innovation Management, v.13, n.6, p.478-496, 1996.

HANSEN, M; BIRKINSHAW, J. The innovation value chain. Harvard Business Review, p. 121-130, 2007.

HARRIS, S.; SUTTON, R. Functions of parting ceremonies in dying organizations. Academy of Management Journal, n. 29, p. 5-30, 1986. 
HAYES, R.; ABERNATHY, W. Managing our way to economic decline. Harvard Business Review, Jul-Ago, 1980.

HODGE JR, M. H. Rate your company's research productivity. Harvard Business Review, v.41, n.6, 1963.

JULIEN, P.A. Small businesses as a research subject: some reflections on knowledge of small Businesses and its effects on economic theory. Small Business Economics, n. 5, 1993.

KARLSSON, H., JOHNSSON, M., BACKSTROM, T. Interview supported innovation audit: how does a complementary interview affect the understanding of an innovation audits results when the interview is based on the audit statements. The 3rd ISPIM Symposium. Quebec, 2010.

KERSSENS-VAN DRONGELEN, I. C.; COOK, A. Design principles for the development of measurement systems for research and development processes. R\&D Management, v.27, n.4, p.345-357, 1997.

KERSSENS-VAN DRONGELEN, I. C.; NIXON, B. Performance measurement in industrial R\&D. International Journal of Management Reviews, v.2, n.2, p.111-143, 2000.

KIDDER, T. Soul of a new machine. New York: 1982.

$\mathrm{KIM}, \mathrm{B}$; $\mathrm{OH}, \mathrm{H}$. An effective R\&D performance measurement system: survey of Korean $R \& D$ researchers. International Journal of Management Science, n. 30, p. 19-31, 2002.

KLAAS, B. S. et al. The adoption of human capital services by small and medium enterprises: a diffusion of innovation perspective. Journal of Business Venturing, $n$. 25, p. 349-360, 2010.

KOBERG, C. S.; DETIENNE, D. R.; HEPPARD, K. A. An empirical test of environmental, organizational, and process factors affecting incremental and radical innovation. Journal of High Technology Management Research, vol.14, p.21-45, 2003. 
LAFORET, S. Size, strategic, and market orientation affects on innovation. Journal of Business Research, v. 61, n.7, pg. 753-764, 2008.

LEIFER, R. et al. Radical innovation: how mature companies can outsmart upstars. Boston: HBSP, 2000.

$\mathrm{LOCH}, \mathrm{C}$. et al. Measuring development performance in the electronics industry. Journal of Product Innovation Management, v.13, n.1, p.3-20, 1996.

MARCH-CHORDA, I.; GUNASEKARAN, A.; LLORIA-ARAMBURO, B. Product development process in Spanish SMEs: an empirical research. Technovation, v. 22, pg. 301-312, 2002.

MCGRATH, M. E.; ROMERI, M. N. The R\&D effectiveness index: a metric for product development performance world class design to manufacture, vol.1, n.4, p.24-31, 1994.

MOSER, M. R. Measuring performance in R\&D settings. Research Management, v.28, n.5, 1985.

MOULTRIE, J.; CLARKSON, P. J.; PROBERT D. Development of a design audit tool for SMEs. Journal of Product Innovation Management, n. 24, p. 335-368, 2007.

NEELY, A. The performance measurement revolution: why now and what next? International Journal of Operations and Production Management, v. 19, n. 2, 1999.

O'CONNOR, G. C.; HENDRICKS, R.; RICE, M. P. Assessing transition readiness for radical innovation. Research Technology Management, vol.45, n.6, p.50-56, Nov. 2002.

OECD. Oslo Manual - Guidelines for collecting and interpreting innovation. OECD Publishing, 2005.

OJANEN, V.; VUOLA, O. Coping with the multiple dimensions of R\&D performance analysis. International Journal of Technology Management, v.33, n.2-3, p.279-290, 2006. 
OLIVEIRA, A. R. Uma avaliação de sistemas de medição de desempenho para P\&D implantados em empresas brasileiras frente aos princípios de construção identificados na literatura. 2010. Tese de Doutorado - Universidade Federal do Rio de Janeiro, COPPE, Rio de Janeiro, 2010.

OSAMA, A. Multi-attribute strategy and performance architectures in R\&D: the case of balanced scorecard. 2006. Doctorate Thesis - RAND Graduate School, 2006.

PETTIGREW, A. Longitudinal field research on change: theory and practice. National Science Foundation Conference on Longitudinal Research Methods in Organization. Austin: 1988.

PINFIELD, L. A field evaluation of perspectives on organizational decision making. Administrative Science Quarterly, n. 31, p. 365-388, 1986.

PORTER, M. The competitive advantage of nations. London: Free Press, 1990.

QUINN, J. B. How to evaluate research output. Harvard Business Review, v.37, n.2, 1960.

REIS, D. R. Gestão da inovação tecnológica. São Paulo: Editora Manole, 2004.

REIS, G. H. S. S.; SALERNO, M. S. Avaliação do desempenho de micro e pequenas empresas: survey a partir do PEIEX-APEX. In: XXXV ENCONTRO NACIONAL DE ENGENHARIA DE PRODUÇÃO, 2015, Fortaleza. Anais eletrônicos... Fortaleza: ENEGEP, 2015.

ROSENBUSCH, N.; BRINCKMANN, J.; BAUSCH, A. Is innovation always beneficial? A meta-analysis of the relationship between innovation and performance in SMEs. Journal of Business Venturing, v.26, n.4, pg. 441-457, 2011.

ROTHWELL, R. Sucessful industrial innovation: critical factors for the 1990s. R\&D Management, n. 22, p. 221-239, 1992.

ROTHWELL, R.; DOGSON, M. Technology-based SMEs: their role in industrial and economic change. Buckinghamshire, UK: Inderscience Enterprises, 1993. 
RUBENSTEIN, A. H. Setting criteria for R\&D. Harvard Business Review, v.35, n.1, 1957.

SALERNO, M. S.; GOMES, L. A. V.; SILVA, D. O.; BAGNO, R. B.; FREITAS, S. L. T. U. Innovation processes: which process for which project? Technovation, n. 35, p. 5970, 2015.

SCHUMANN, P. A. J. et al. Measuring R\&D performance. Research Technology Management, v.38, n.3, p.45-54, 1995.

SCHUMPETER, J. A. Teoria do desenvolvimento econômico. Rio de Janeiro: Editora Fundo de Cultura, 1961.

SCOZZI, B.; GARAVELLI, C.; CROWSTON, K. Methods for modelling and supporting innovation processes in SMEs. European Journal of Innovation Management, v.8, n.1, pg. 120-137, 2005.

SRINIVASAN, R. et al. Technological opportunism and radical technology adoption: an application to e-business. Journal of Marketing, v. 66, n. 3, pg. 47-61, 2002.

TIDD, J.; BESSANT, J. R.; PAVITT, K. Managing innovation: integrating technological, market and organizational change. Wiley, 3rd edition, 2005.

TIDD, J. et al. Gestão da inovação. Porto Alegre: Ed. Bookman, 2008.

TIPPING, J. W.; ZEFFREN, E. et al. Assessing the value of your technology. Research Technology Management, v.38, n.5, 1995.

UTTERBACK, J. M. The process of technological innovation within the firm. Academy of Management Journal, p. 75-88, 1971.

VAN DE VRANDE, V.; JONG, J. P. J., VANHAVERBEKE, W.; ROCHEMONT, M. Open innovation in SMEs: trends, motives and management challenges. Technovation, $v$. 29, pg. 423-437, 2009.

VASCONCELLOS, E.; OHAYON, P. Como avaliar projetos de pesquisa e desenvolvimento. Revista da Administração, v. 24, 1988. 
VERHAEGHE, A.; KFIR, R. Managing innovation in a knowledge intensive technology organisation. R\&D Management, v. 32, n. 5, p. 409-417, 2002.

VOS, J. P.; KEIZER, J. A.; HALMAN, J. I. M. Diagnosing constraints in knowledge of SMEs. Technological Forecasting and Social Change, v. 58, n. 3, p. 227-239, 1998. WHEELWRIGHT, S. C.; CLARK, K. B. Revolutionizing product development: quantum leaps in speed, efficiency, and quality. New York, NY: Free Press, 1992.

YIN, R. K. Case study research: design and methods. Thousands Oaks, CA: Sage, 2003. 


\section{ANEXO - ROTEIRO DA FASE I}

\section{A) Cadastro}

Empresa:

CNPJ:

Nome do contato:

Telefone:

Endereço:

Data de preenchimento:

1) Qual é o número de funcionários da empresa?
( ) Menos de 10
( ) De 10 a 50
( ) De 50 a 100
( ) Mais de 100

2) Qual é o ramo de atividade da empresa?

\section{B) Caracterização e Estratégia}

3) Em qual elo da cadeia de produção se enquadra a empresa?

( ) Fornecedor de matéria-prima

( ) Fornecedor de componentes manufaturados

( ) Indústria de equipamentos

( ) Fabricante do produto final da cadeia 
( ) Distribuidor

( ) Varejo

( ) Serviços

( ) Outro

4) Qual é o posicionamento estratégico da empresa?

( ) Custos: obter o máximo volume de produção; redução de custos operacionais; competição por preços

( ) Diferenciação: liderança na qualidade, serviços e inovação; desenvolvimento e produção adaptados às necessidades dos clientes

5) Quantidade de produtos do mix:
( ) Até 10
( ) De 10 a 20
( ) De 20 a 50
( ) Mais de 50

6) Como é o ambiente externo da empresa?

( ) Marcado por mudanças rápidas e radicais por causa de evoluções tecnológicas e mercadológicas: há lançamento constante de gerações de produtos totalmente novas e mudanças na liderança do mercado são frequentes

( ) Mudanças rápidas, mas sem grandes saltos tecnológicos ou rupturas de mercado

( ) Mudanças são lentas e incrementais: concorrentes lançam apenas pequenas atualizações em seus produtos

( ) Mudanças raramente ocorrem: concorrentes dificilmente lançam novos produtos 
7) Qual é a estratégia de inovação da empresa? (assinale as opções pertinentes)

( ) A empresa possui uma estratégia explícita de lançamento de produtos ou serviços para os dois próximos anos

( ) A empresa possui uma estratégia tecnológica visando manter o fluxo contínuo de lançamento de produtos e/ou serviços da empresa nos próximos dois anos

( ) A empresa adota uma estratégia de inovação voltada para ser a pioneira no setor

( ) A empresa adota uma estratégia de inovação voltada para ser a seguidora rápida

( ) Em geral, a empresa é uma das últimas a entrar no mercado

8) Para a empresa, a inovação ocorre:

( ) Por meio de um processo sistemático de lançamento de novos produtos e/ou serviços

( ) De maneira informal baseada na liderança da alta direção da empresa

( ) Somente em casos mais extremos como exigências dos clientes ou lançamento de produtos e/ou serviços dos concorrentes

( ) Estamos desenvolvendo o nosso primeiro produto

( ) Não ocorre inovação

\section{C) Organização para Inovar}

9) Estrutura organizacional para inovar: (assinale as opções pertinentes)

( ) Possui diretoria de inovação

( ) Possui departamento ou área de inovação

( ) Possui um comitê de inovação

( ) A inovação corresponde a uma gerência na empresa 
( ) Possui times de projetos dedicados à inovação em produtos, serviços ou processos produtivos

( ) Possui diretoria de tecnologia

( ) Possui time de desenvolvimento de tecnologias

( ) Possui equipe de marketing focada em inovação

( ) Possui equipe de design na empresa

( ) Possui área de inovação aberta e gerenciamento de parcerias

( ) Possui comunidades de práticas ou encontros períodicos para compartilhar aprendizados e novos conhecimentos

( ) Possui uma áerea ou equipe dedicada aos projetos mais radicais ou incertos

10) Tipo predominante e evolução da carreira

( ) A empresa possui trajetórias bem definidas de carreira que permitam tanto evoluir tecnicamente como gerencialmente

( ) A evolução na carreira é mais ligada ao aspecto gerencial

( ) A evolução na carreira ocorre graças ao aumento da expertise técnica

11) Ambiente interno para inovar (assinale as opções pertinentes)

( ) A organização valoriza o aprendizado por tentativa e erro

( ) A organização procura incentivar os funcionários a investir em novas soluções

( ) A organização incentiva formalmente (ex: via bonus) que os funcionários contribuam com novas ideias

( ) Funcionários possuem tempo livre durante o trabalho para desenvolver ideias 
( ) A organização valoriza o trabalho em equipe

12) Há práticas e ambiente de estímulo à inovação? (assinale as opções pertinentes)

( ) Grupos de discussão

( ) Grupos de melhorias

( ) Caixas de sugestão

( ) Programas de premiação de ideias

( ) Bolsas de pesquisa

( ) Engenharia simultânea

( ) Outro

\section{D) Gestão da Inovação}

13) Nos últimos três anos, a sua empresa: (assinale as opções pertinentes)

( ) Introduziu um novo produto ou serviço

( ) Introduziu melhorias significativas nas características ou usos de seus produtos ou serviços existentes

( ) Implementou um novo processo de produção

( ) Implementou um novo processo de entrega

( ) Melhorou significativamente um processo de produção

( ) Implementou um novo processo nas práticas de negócios da empresa

( ) Mudou significativamente a embalagem do produto

( ) Mudou significativamente o posicionamento da empresa ou de produto no mercado 
( ) Criou um novo mercado, com novos clientes

14) A maioria das inovações da empresa:

( ) Ainda não tivemos inovações

( ) Foi novo para empresa, mas já existia no Brasil

( ) Foi novo para o Brasil, mas já existia em outros países

( ) Novo para o mundo

15) A empresa possui processo formal para: (assinale as opções pertinentes)

( ) Gerar novas ideias envolvendo o time de inovação

( ) Gerar e/ou coletar ideias entre departamentos ou pessoas que estão fora da área formal de inovação ou/e desenvolvimento de produtos

( ) Gerar ou coletar ideias a partir de clientes, universidades e/ou fornecedores

( ) Pré-desenvolver ou amadurecer ideias antes de transformá-las em projetos

( ) Selecionar projetos de inovação

( ) Desenvolver projetos de inovação

16) A sua empresa possui indicadores de desempenho para inovação?
( ) Sim
( ) Não

17) Propriedade intelectual: patentes e marcas
( ) Possui
Quantos? 

( ) Não possui, mas já solicitou
( ) Não possui
( ) Não conhece processos

18) O fluxo de desenvolvimento dos projetos de inovação predominante é:

( ) Tradicional: geração de ideias $>$ seleção $>$ desenvolvimento >> lançamento/vendas

( ) Vendas antecipadas: ideia construída junto ao cliente >> vendas $>>$ desenvolvimento >> entrega

( ) Pedido fechado: cliente especifica o pedido >> vendas >> desenvolvimento >> entrega

( ) Participação em editais públicos: pré-desenvolvimento e elaboração de um projeto para participar do edital >> vencendo o edital/difusão >> desenvolvimento >> entrega

( ) Processo com pausa: aguarda progresso tecnológico: geração de ideia >> seleção >> desenvolvimento | > difusão II >> aguarda evolução da tecnologia >> desenvolvimento II >> difusão II

( ) Processo com pausa: esperando o mercado: geração de ideia >> seleção >> desenvolvimento I >> difusão II >> aguarda evolução do mercado >> desenvolvimento II >> difusão II

( ) Processo com atividades paralelas: geração de ideias >> seleção >> desenvolvimento em paralelo com a difusão

\section{E) Clientes e Mercado}

19) Qual foi o faturamento médio no último ano?

( ) Até $\mathrm{R} \$ 200$ mil ao mês

( ) De $\mathrm{R} \$ 200$ mil a $\mathrm{R} \$ 1,3$ milhão ao mês

( ) De $\mathrm{R} \$ 1,3$ milhão a $\mathrm{R} \$ 7,5$ milhões ao mês 
( ) De $\mathrm{R} \$ 7,5$ milhões a $\mathrm{R} \$ 25$ milhões ao mês

( ) Mais de $\mathrm{R} \$ 25$ milhões ao mês

20) O preço dos produtos é:

( ) Mais caro do que concorrência nacional

( ) Mais caro do que concorrência internacional

( ) Preços similares aos concorrentes nacionais

( ) Preços similares aos concorrentes internacionais

( ) Mais barato do que concorrência nacional

( ) Mais barato do que concorrência internacional

\section{F) Recursos e Obstáculos para Inovar}

21) A empresa possui experiência nos instrumentos de apoio à inovação? (assinale as opções pertinentes)

( ) Em programas de subvenção da FINEP e outras agências do governo

( ) Em programas de financiamento da inovação de agências do tipo FINEP

( ) Lei do Bem

22) Quais são os maiores desafios para a empresa melhorar a inovação em sua organização? (assinale as opções pertinentes)

( ) Melhorar o projeto do produto, compreendendo com maior profundidade as necessidades dos clientes e superando o desempenho do produto

( ) Melhorar o design ou/e o posicionamento do produto no mercado 
( ) Conseguir captar melhores ideias dentro da empresa

( ) Conseguir captar melhores ideias em parceiros-chave da empresa: fornecedores, clientes, universidades, entre outros

( ) Selecionar melhor os projetos de inovação, com critérios mais claros e balanceados (ex: projetos de inovação radical e incremental)

( ) Conseguir desenvolver sistematicamente produtos

( ) Passar a inovar em outras dimensões: serviços, modelos de negócios e tecnologia

( ) Conseguir melhorar o lançamento e a difusão das inovações dentro e/ou fora da empresa 